\title{
AVALIAÇÃO DO XISTO E ESCÓRIAS NA NUTRIÇÃO E PRODUÇÃO DO TOMATEIRO E EM ATRIBUTOS QUÍMICOS E BIOLÓGICOS DO SOLO
}

\author{
Hamilton Seron Pereira \\ M.S. Engenheiro Agrônomo
}

Orientador: Prof. Dr. GODOFREDO CESAR VITTI

Tese apresentada à Escola Superior de Agricultura "Luiz de Queiroz", da Universidade de São Paulo, para obtenção do título de Doutor em Agronomia. Área de Concentração: Solos e Nutrição de Plantas.

P I R A C I C A B A

Estado de São Paulo - Brasil

Junho - 1999 
Dados Internacionais de Catalogação na Publicação (CIP) DIVISÃo DE BIBLIOTECA E DOCUMENTAÇÃO - Campus "Luiz de Queiroz"/USP

\author{
Pereira, Hamilton Seron \\ Avaliação do xisto e escórias na nutrição e produção do tomateiro e em \\ atributos quimicos e biológicos do solo / Hamilton Seron Pereira. - - Piracicaba, \\ 1999. \\ $89 \mathrm{p.}$ \\ Tese (doutorado) - Escola Superior de Agricultura Luiz de Queiroz, 1999. \\ Bibliografia. \\ 1. Escória 2. Nutrição vegetal 3. Produção vegetal 4. Propriedade fisico- \\ quimica do solo 5 . Residuo industrial 6 . Tomate 7. Xisto 1. Título
}

CDD 635.642

Termitida a copia total o p parcial deste docunento, lesule que citada a fonle 0 Autor" 
Aos meus pais,

Altair e Maria Aparecida

e meus irmãos

Ronaldo, Luciana e Daniel

OFEREÇO

A minha esposa, Alessandra e meu filho, Murilo 


\section{AGRADECIMENTOS}

Mais uma etapa foi finalizada

Aproveito este momento para agradecer

\section{Assim, AGRADECO}

A DEUS, por ser meu guia e estar sempre presente em minha vida.

A minha família, pela paciência, compreensão e amizade.

Ao Prof. Dr. Godofredo Cesar Vitti, Professor Titular do Departamento de Ciência do Solo e Nutrição de Plantas da ESALQ/USP, pela orientação e acima de tudo pela amizade e paciência.

\footnotetext{
À Escola Superior de Agricultura "Luiz de Queiroz" (ESALQ/USP) pela oportunidade da realização do Curso de Doutorado, e aos professores pelos ensinamentos.
}

À Fundação de Amparo a Pesquisa do Estado de São Paulo (FAPESP) pela bolsa e recursos para a realização das pesquisas. 
À PETROBRAS-SIX na pessoa do Dr Rubens Eduardo Medeiros Novicki, ao Dr Wilson Caixeta Piau da Silifertil e ao Eng. Agr ${ }^{\circ}$ Adelardo Antônio Brajão da Fertil pelas doações das matérias-primas utilizada no estudo e pelas informações prestadas.

Aos funcionários dos laboratórios do Departamento de Solos e Nutrição de Plantas da Escola Superior de Agricultura "Luiz de Queirós", e em especial aos químicos Luiz A. Silva Júnior, Marcos Antônio F. de Camargo e João Álvaro Granja, pelo auxílio prestado para a execução dos trabalhos de análises.

À Maria Helena de Oliveira do laboratório da Cooperativa dos Produtores de Café de Gauxupé (COXUPÉ) pela colaboração nas análises de metais pesados.

Aos colegas de curso e todos que, direta ou indiretamente, contribuíram para a realização deste trabalho. 


\section{SUMÁRIO}

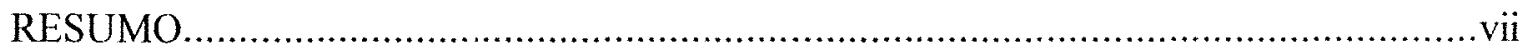

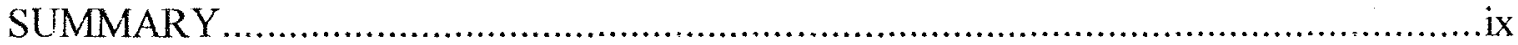

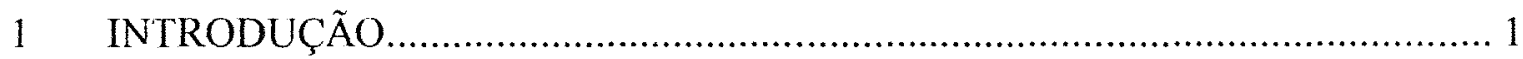

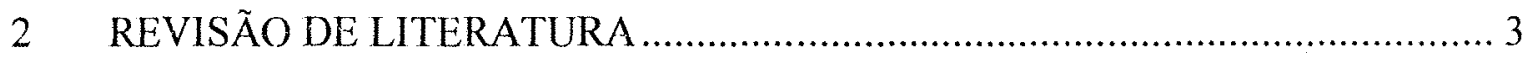

$2.1 \quad$ O aproveitamento de resíduos industriais ................................................. 5

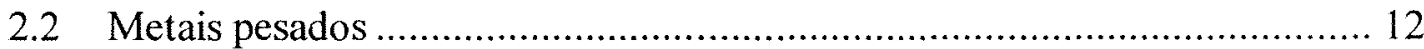

2.3 Caracterização do xisto retortado ................................................. 17

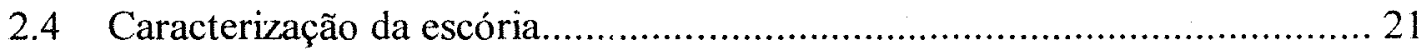

2.5 Silício nos resíduos, no solo e nas plantas........................................... 24

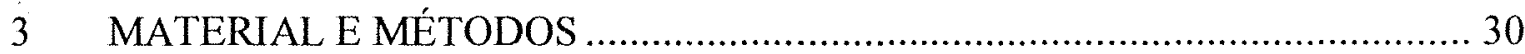

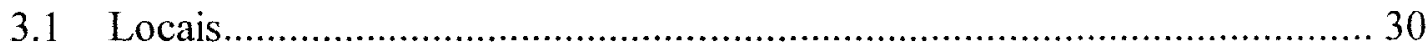

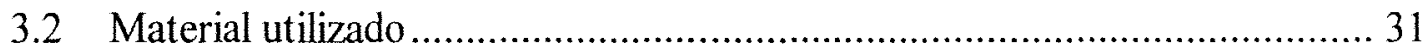

3.3 Delineamento experimental e análise dos resultados ................................. 32

3.4 Instalação e condução dos experimentos.................................................. 32

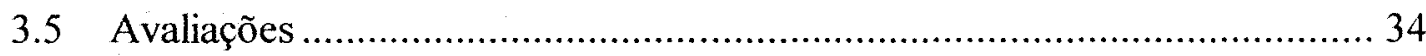

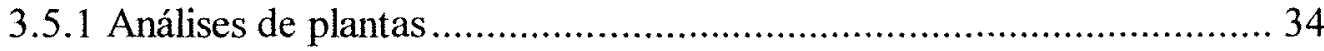

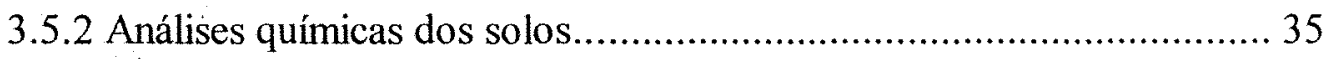

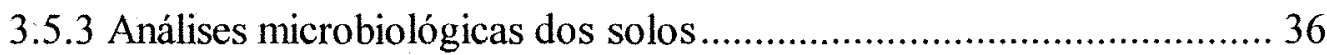

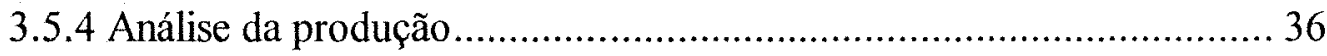

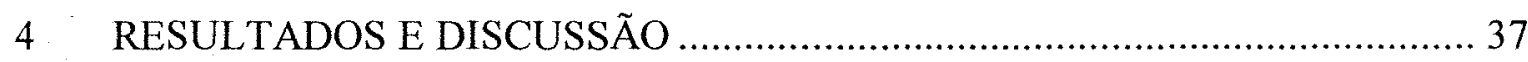

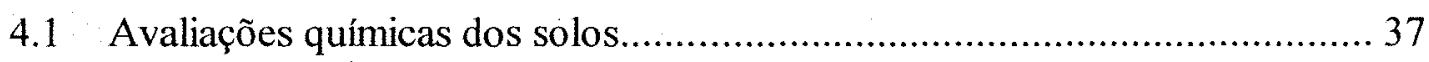

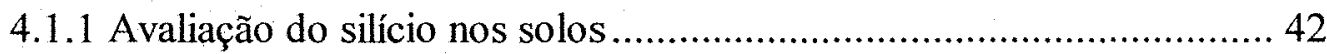

4.1.2 Avaliação de metais pesados nos solos ............................................. 44

4.2 Análises químicas do material vegetal......................................................4 47

4.2.1 Avaliação nutricional do tomateiro ................................................ 47

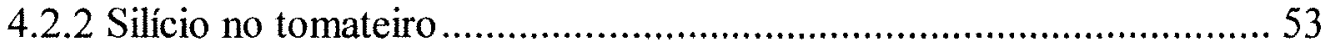

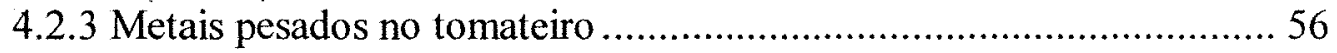




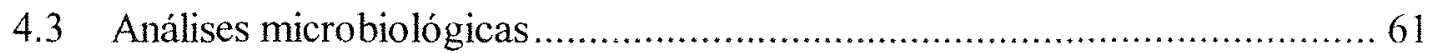

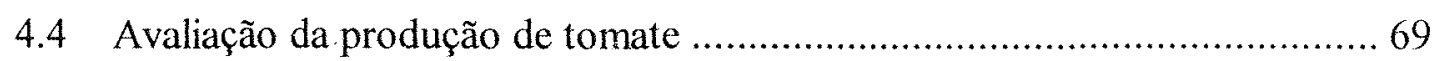

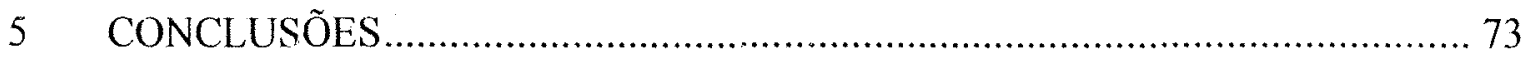

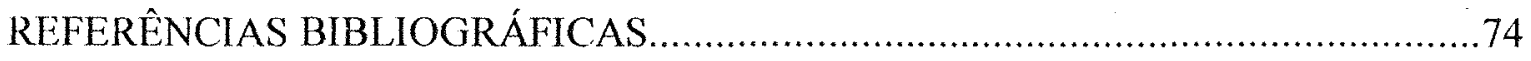




\title{
AVALIAÇÃO DO XISTO E ESCÓRIAS NA NUTRIÇÃO E PRODUÇÃO DO TOMATEIRO E EM ATRIBUTOS QUÍMICOS E BIOLÓGICOS DO SOLO
}

\author{
Autor: HAMILTON SERON PEREIRA \\ Orientador: Prof. Dr. GODOFREDO CESAR VITTI
}

\section{RESUMO}

Na produção industrial há processos que geram residuos, muitos destes podem ser reaproveitados, ao invés de serem depositados em locais que poderiam causar danos, contaminações ou alterações do meio em que são expostos. O xisto caracteriza-se de uma rocha essencialmente silto-argilosa da formação Iratí, com conteúdo apreciável de matéria orgânica, que sob aquecimento pode produzir óleo, gás e enxofre. Atualmente na unidade de exploração de xisto, após a retirada do óleo, gás e enxofre, este é descartado chegando a um montante de $6.000 \mathrm{Mg} \mathrm{dia}^{-1}$. Outro resíduo ainda muito pouco aproveitado são as escórias, com excelentes propriedades corretivas. No processo de obtenção do ferro gusa, $300 \mathrm{~kg}$ de escórias são produzidos por $\mathrm{Mg}$ de ferro obtido.

Para avaliar o aproveitamento destes resíduos na agricultura, foram realizados dois experimentos com delineamento em blocos ao acaso cultivando-se tomate estaqueado em Podzólicos Vermelho-Amarelos, sob condições de casa-de-vegetação (plasticultura). Foram utilizados nos experimentos xisto retortado em quatro doses $(3,6$, 9 e $12 \mathrm{Mg} \mathrm{ha}^{-1}$ ), duas escórias de alto forno de siderurgia (da Mannesman e Dedini) na dose de $6 \mathrm{Mg} \mathrm{ha}^{-1}$ e o termofosfato, que usa a escória como matéria-prima em seu processo de fabricação, na dose de $2,5 \mathrm{Mg} \mathrm{ha}^{-1}$. Os experimentos constaram de oito tratamentos incluindo a testemunha, com quatro repetições. Todos os tratamentos receberam adubação mineral NPK, inclusive a testemunha. 
Foram avaliados o estado nutricional e a produtividade do tomateiro. Devido a alta concentração de silicatos nos resíduos, foram avaliadas o fornecimento de silício no solo e na cultura; também foram avaliados alguns atributos químicos do solo e alguns atributos biológicos.

Os resultados mostram que as escórias atuaram com eficiência na correção da acidez do solo enquanto que o xisto não alterou o mesmo. $O$ xisto e as escórias aumentaram o teor de silício no solo e na planta, este aumento de silício no solo incrementou a disponibilidade de fósforo, devido a competição direta pelos sítios de adsorção entre os ânions silicato e o fosfato.

O xisto aumentou o teor de enxofre no solo e na planta, apresentando-se eficiente no fornecimento deste elemento para a cultura.

Não verificou-se niveis elevados de metais pesados nos solos e nas plantas, causados pela aplicação dos tratamentos, ficando estes abaixo dos considerados críticos para o solo e que pudessem vir causar danos ao ambiente.

A população bacteriana do solo foi aumentada com a aplicação da escória da Mannesman enquanto que o xisto aumentou a população fúngica, mas não verificou-se danos ao ambiente, tanto por parte de contaminações químicas por metais pesados, como diminuição da atividade biológica do solo, bem como pela diminuição na produtividade do tomateiro em função da aplicação dos tratamentos.

Os produtos utilizados nestes experimentos e nas doses sugeridas podem ser utilizados na agricultura, sejam como corretivos ou como condicionadores de solo. 
EVALUATION OF SCHIST AND SCORIA IN THE NUTRITION AND

PRODUCTION OF TOMATO AND THE EFFECTS ON THE SOIL CHEMICAL AND BIOLOGICAL ATTRIBUTES

\author{
Author: HAMILTON SERON PEREIRA \\ Adviser: Prof. Dr. GODOFREDO CESAR VITTI
}

\title{
SUMMARY
}

Some processes in the industry generate residues, many of these can be reutilized, instead of being deposited in places that could cause problems, contaminate or cause changes in the environment. Schist is a silty-clayey rock of the Iratí formation, with a high content of organic matter, that when heated can produce oil, gas and sulfur. Actually, in the exploitation unit of schist, after the extraction of oil, gas and sulfur, the residue is discarded reaching an amount of $6000 \mathrm{Mg} \mathrm{day}^{-1}$. Another residue that is not reutilized are the scorias, their corrective action has already being demonstrated. In the process for the obtention of the gusa iron, $300 \mathrm{~kg}$ of scorias are produced by iron $\mathrm{Mg}$.

To evaluate the re-utilization of these residues in agriculture, two experiments were performed with a randon complete block desing growing tomato on Alfisols in greenhouse conditions (plasticultura). Four doses of schist were used in the experiments $\left(3,6,9\right.$ and $\left.12 \mathrm{Mg} \mathrm{ha}^{-1}\right)$, two siderurgy high oven scorias (Mannesman and Dedini) with a doses of $6 \mathrm{Mg} \mathrm{ha}^{-1}$ and thermophosphate, that uses scorias in its fabrication process, with a doses of $2.5 \mathrm{Mg} \mathrm{ha}^{-1}$. The experiments had eight treatments including the control, with four repetitions. All the treatments received NPK mineral fertilization, including the control.

The nutritional state and production of tomato were evaluated. Due to the high concentration of silicates in the residue, the addition of silicium to the soil and crop was evaluated; some chemical and biological attributes were evaluated. 
The results showed that the scorias were efficient in the acidity correction while schist did not alter this attribute. Schist and scorias increased the soil and plant silicium content, this increase of silicium in the soil increased the availabily of phosphorus, due to the direct competition for the adsorption sites between silicium and phosphorus.

Schist increased the soil and plant sulfur content, being efficient in the supply of this element to the crop.

High levels of heavy metals were not verified in soils and in the plants caused by the application of these treatments. The level remained below those considered critical for the soil and that could harm the environment.

The soil's bacterial population was increased with the application of Mannesman scoria while schist increased the fungal population, but environmental problems not were identified, such as the chemical contamination by heavy metals, as the diminishing of the soil biological activity, as well as the productivity decrease as a function of the applied treatments.

The products used in these experiments and in the suggested doses can perfectly be used in agriculture, as correctives or as soil conditioners. 


\section{INTRODUÇÃO}

Em quase todo processo industrial há geração de resíduos, e estes vem se tornando problemas para o desenvolvimento industrial, impedindo até a instalação de novas indústrias. Dependendo do setor de produção industrial, e do tipo de tratamento que são submetidos, os resíduos se constituem en sérios problemas na contaminação e alterações do meio em que são descartados.

Atualmente muitos pesquisadores estão preocupados na obtenção de produtos mais baratos que possam ser utilizados como fertilizantes e/ou corretivos de solo; e na diminuição do impacto ambiental causado pelo acúmulo desses materiais em solos e cursos d'água. Pesquisas estão sendo realizadas visando o aproveitamento desses resíduos, mas ainda são poucas as pesquisas desenvolvidas em face ao número dos mesmos gerados pelas industrias.

A legislação sobre o ambiente vigente no País exige que todos os resíduos líquidos produzidos devam ser tratados para serem dispostos nos cursos d'água. Torna-se evidente que este material deva apresentar condições perfeitamente condizentes com o meio que deverá recebê-lo, em termos de compatibilidade de propriedades e características químicas, fisicas e biológicas. Para que a deposição do resíduo não produza alteração ou modificação nas características originais do meio em questão, especialmente se estas alterações forem fatores ou elementos de degradação.

Muitas indústrias, já reaproveitam seus resíduos, como a indústria sucroalcooleira, no caso da vinhaça que agredia o ambiente, principalmente quando despejada em rios; e hoje é reaproveitada na própria lavoura canavieira trazendo economias no consumo de fertilizantes e preservando o ambiente. 
O Brasil sendo detentor da segunda maior reserva de xisto conhecida no mundo, e em função da crise do petróleo nos anos 70, a PETROBRAS iniciou um programa de exploração de xisto na jazida de São Mateus do Sul, no Estado do Paraná. Um dos principais problemas ambientais que ocorre com o processo de exploração é a produção de quantidades maciças de xisto retortado de alta alcalinidade. Este residuo depositado em larga escala libera elementos tóxicos no ambiente, poluindo o solo, a água de superficie e até o ar atmosférico.

As escorias são resíduos das industrias siderúrgicas, sendo subprodutos da produção de ferro gusa ou de aço. Estes materiais depositados em áreas próximas às industrias, formam pilhas, que expostas a chuva e vento também poluem o ambiente. Devido as suas características químicas, se mostram favoráveis ao uso na agricultura, promovendo a melhoria de solos degradados de baixa fertilidade e principalmente fornecem o silício escasso em nossos solos que apresentam elevado grau de intemperismo. As escórias também podem ser usadas como corretivos de solos devido ao alto indice de basicidade.

Muitos trabalhos vem demonstrando os efeitos benéficos do silício, entretanto, os mecanismos fisiológicos desse elemento, ainda hoje não são bem conhecidos. No Japão, onde a cultura do arroz é importante economicamente, vários estudos com esta cultura foram realizados $\mathrm{em}$ diferentes universidades e estações experimentais. Os resultados dessas pesquisas foram utilizados como base para a produção de fertilizantes silicatados, e o Japão se tornou o primeiro país a autorizar a produção dos mesmos. Atualmente, existe a necessidade de determinar a eficiência do silício como fertilizante no aumento da produtividade e no controle de pragas e doenças de diversas culturas, associada a fontes, formas e quantidades aplicadas de fontes silicatas.

O presente trabalho teve como objetivo avaliar a possibilidade do reaproveitamento do xisto retortado na agricultura como fonte de silício e condicionador de solo, comparado à escórias de siderurgia e ao termofosfato (fonte de $\mathrm{P}_{2} \mathrm{O}_{5}$ e de silício). 


\section{REVISÃO DE LITERATURA}

No desenvolvimento industrial há um processo de geração de resíduos na qual sua aplicação pura e simples ao ambiente deve ser evitada, devido as inúmeras transformações que estes novos componentes imprimem ao meio receptor. Infelizmente não é o que se verifica, pois o elemento solo passou a se constituir em um depósito receptivo a todo e qualquer tipo de deposição, independentemente do grau de periculosidade ou finalidade a que se destina a eliminação de resíduos. Para a empresa o que interessa é a solução do problema, que é sua eliminação, mas para a coletividade interessa esta eliminação feita sob moldes técnicos onde o meio receptor não sofra e nem se contamine com esta prática (Aloisi, 1995).

No Brasil a primeira tendência em se aplicar tal metodologia teve seu início marcado por acidente em Usina de cana-de-açúcar onde, por vazamento acidental em lagoa de vinhaça, houve deposição do líquido em um talhão da cultura. Em função da resposta da cultura à deposição, alguns estudos se iniciaram e atualmente, tornou-se prática usual em qualquer empresa do ramo (Aloisi, 1995).

A partir dos anos 80 o solo passou a ser visto como meio alternativo, para ser usado como receptor. Surgiu assim, sua nova utilização que, mesmo pôr força de lei, passou a receber os resíduos industriais. Mas, a preocupação que tal implantação poderia causar ao ambiente, também começou a ser tratada de forma técnica, sendo Nemeth (1982) o primeiro autor a ressaltar que os propósitos e contradições de cada método e a destinação deveriam ser melhor discutidos, para que o sucesso do tratamento fosse alcançado. Assim, deveriam ser considerados os equipamentos a serem empregados, os tipos de culturas a serem adotadas, e os objetivos e práticas requeridas para um monitoramento efetivo a ser implementado. Corey (1984), afirmou que fatores 
legislativos, econômicos e técnicos influenciam a seleção de sistemas de solo para manejo de resíduos industriais. Apontou o "landfarming" como técnica viável e útil para colocar pequenas frações de resíduos no solo e como o mais apropriado para isto, são aqueles não tóxicos e biodegradáveis, evitando a utilização de materiais prejudiciais como os pesticidas que deveriam ser depositados ao solo somente em casos muito especiais, o que discorda frontalmente da afirmação de Kaufman (1983) que indica a disposição no solo de resíduos fenois clorados, tal como o 2-4-D, como prática mais adequada. Mas, a tendência de se utilizar os resíduos como fonte nutricional para vegetais, começou a surgir no meio técnico. Reynolds (1979), discutiu os vários aspectos da aplicação de efluentes em solos agrícolas, incluindo o delineamento do projeto, o custo do sistema de aplicação, os efeitos causados, o comportamento dos nutrientes no solo, a contaminação do solo com bactérias e vírus, os fatores afetando o destino dos metais pesados, e a presença de patógenos e pesticidas aplicados junto com o efluente. Hornick \& Kaufman (1983), apresentaram ampla discussão sobre a composição de restos têxteis, a presença de constituintes orgânicos pesados e o seu valor como fertilizante. Tauchnitz et al. (1983) em experimentos com solução nutritiva com a cultura do milho suprido com óxidos de metais pesados, mostraram o efeito dos tratamentos na planta. Sobre a raiz notaram que existiu a seguinte ordem decrescente no desenvolvimento quando expostos ao óxidos: $\mathrm{Mn}>\mathrm{Pb}>\mathrm{Fe}>\mathrm{Cu}>\mathrm{Zn}>\mathrm{Ni}>\mathrm{Cd}>\mathrm{Cr}$. Concluíram que há necessidade de se proceder estudos mais aprofundados e a longo prazo sobre a disposição de restos contendo metais pesados. King (1982), conduzindo experimento para determinar se resíduos industriais não tratados poderiam ser aplicados ao solo sem afetar o crescimento da cultura, das propriedades do solo ou causar um desequilíbrio na água do solo; se valeu de dois resíduos tratados e não tratados, irrigando uma gramínea, por dois anos. Concluiu não haver necessidade de pré-tratamento, e que a produção de grama nos dois tipos de resíduo foram semelhantes. A recuperação de resíduos via colheita foi $10 \%$ maior no não tratado; as doses de $\mathrm{Ni}, \mathrm{Pb}$ e $\mathrm{Cr}$ em amostras de não tratados aumentaram gradativamente sem contudo atingir níveis tóxicos, houve aumento significativo de $10 \%$ nos teores de $\mathrm{P}, \mathrm{K}, \mathrm{Ca}, \mathrm{Na}$ trocável, e os valores de $\mathrm{pH}$ de 7,4 para 7,8. 


\subsection{0 aproveitamento de resíduos industriais}

Dados mais consistentes e aplicáveis surgem à medida em que mais estudos de sistema de incorporação, ou deposição, ao solo são realizados. A partir de sua utilização mais freqüente, problemas passam a ser identificados, resultados são mais discutidos, e diretrizes mais amplas e aplicadas são propostas. Em se tratando de resíduos que possam acarretar riscos ao meio, a pesquisa deve fornecer elementos para o estabelecimento de normas ou diretrizes para sua implantação. Assim ocorreu com Ritter (1985) que, utilizando dois resíduos não biodegradáveis, obtidos através do processamento do nylon, em condições de casa de vegetação e em laboratório, trabalhou com colunas de solo e lisimetros de adsorção para medir os efeitos dos resíduos na água do solo. A fitotoxidez foi medida em uma correlação de massa e a taxa de degradação por microorganismos do solo, através de uma série de respirômetros de Warburg e em experimentos de desidrogenase. Os resíduos mostraram adsorção limitada nas colunas de solo e em lisimetros, sendo que suas características de adsorção não se encaixavam nas isotermas de Langmuir ou de Freundlich, apresentaram efeitos tóxicos quando aplicados em altas taxas na vegetação, e degradação lenta desenvolvida pelos microorganismos. Em decorrência desse estudo, normatizou-se pela não aplicação desses resíduos por causarem contaminações na água do solo.

Os resíduos de petróleo são considerados os mais problemáticos. Brown et al. (1983), usando a respirometria, avaliaram os efeitos da adição de nutrientes, através da proporção e freqüência de aplicação, na biodegradação de dois resíduos oleosos no solo. A biodegradação mais rápida foi obtida com lodo de refinaria, quando a aplicação de nitrogênio complementar reduziu a relação C:N para 9:1; e quando o NPK adicionado foi feito na proporção de 12:4:1. Pequenas e freqüentes aplicações desses resíduos resultaram em aumento na respiração quando comparado a uma aplicação simples equivalente, indicando que a aplicação em pequenas proporções de lodo resultou em uma decomposição mais rápida. A quantidade total de bactérias do solo foi maior quando a 
adição de lodo atingiu a marca de $1 \%$, sendo que nas proporções de 5 a $10 \%$, a população microbiana sofreu redução. Resultados semelhantes foram apresentados por Hornick et al. (1983), no mesmo tipo de material e com a discussão de características do resíduo e de sua degradação biológica.

Outro resíduo de petróleo produzido é a água residual, onde seus constituintes são ativados e se constituem numa quantidade razoável de residuo sólido diluído. Tedesco et al. (1988), trabalhando com este tipo de residuo, promoveram sua aplicação em vasos e após os estudos, apresentaram os seguintes resultados: a) a decomposição dos resíduos no solo, calculada pela evolução do gás carbônico, foi de $2,7 \%$ de perda de $\mathrm{C}$ na forma de gás, em relação ao carbono adicionado, durante 50 dias e a $27^{\circ} \mathrm{C}$, numa taxa de aplicação de $24 \mathrm{Mg} \mathrm{ha}^{-1}$; b) houve um enriquecimento de $\mathrm{N}, \mathrm{C}$ e $\mathrm{P}$ no horizonte superficial; c) aumentos nas concentrações de $\mathrm{Na}, \mathrm{Cu}$, $\mathrm{S}$ e na condutividade elétrica; d) os níveis das concentrações de $\mathrm{Zn}, \mathrm{Cr}$, Cd e Ni aumentaram mas ficaram abaixo do limite tóxico. Concluíram que, se a condução desta deposição em condições de campo fosse análoga ao do experimento, os resíduos poderiam ser assim dispostos durante muitos anos sem haver nenhum risco ambiental.

Em experimento análogo no Brasil Simon et al. (1991) promoveram o tratamento de Digitaria decumbens com este lodo. Análises de lixiviação foram conduzidas e os resultados principais foram: a) houve maior crescimento na produção da gramínea; b) maior solubilização de íons lixiviados (sódio, sulfato e cloreto), com conseqüente aumento na condutividade elétrica; c) $\mathrm{K}, \mathrm{B}, \mathrm{NH}_{3}$ e valor de pH não foram afetados; d) a quantidade mínima de lodo a ser utilizada para causar um crescimento na concentração de nitratos lixiviados, é de $40 \mathrm{Mg} \mathrm{ha}^{-1}$ ano $^{-1}$; e) os metais pesados como : $\mathrm{Cu}, \mathrm{Zn}, \mathrm{Cr}, \mathrm{Pb}, \mathrm{Cd}$ e $\mathrm{Hg}$ foram efetivamente imobilizados no solo resultando em níveis próximos aos da água potável.

Ritter \& Eastburn (1982), trabalhando com lodo de aves domésticas, originado da dissolução por flotação, aplicaram este resíduo no solo em proporções 0 ; $168 ; 336$ e $672 \mathrm{~kg} \mathrm{~N} \mathrm{ha}^{-1}$. Após estudos, verificaram aumento na concentração de nitrato no lençol de água, com a aplicação de $672 \mathrm{~kg} \mathrm{~N}$ ha $^{-1}$; mas, o alto teor de gordura contido 
no lodo não diminuiu a permeabilidade do solo, ou teve qualquer outro efeito adverso em suas propriedades. Carr et al. (1988), utilizando-se de um residuo semelhante, testou-o como fonte alternativa de $\mathrm{N}$ em campos para produção de milho. Demonstraram que o milho pode se desenvolver com sucesso quando usaram o lodo como fonte exclusiva de $\mathrm{N}$ e que as produções neste tratamento apresentaram diferença significativa em relação as formulações nitrogenadas minerais.

Guichet et al. (1991) analisaram um solo classificado como Rendzina ("calcioaquoll"), da região oeste da França, que recebeu durante 25 anos, resíduos da indústria de processamento de queijo. Esta aplicação semanal em volume de $5.000 \mathrm{~m}^{3}$ $\mathrm{ha}^{-1}$, equivalente a uma irrigação média mensal de $45 \mathrm{~mm}$ de água. Através da análise de amostras de três camadas solos tratados e não tratados, obtiveram os seguintes resultados: a) a aplicação regular do efluente resultou em aumento duas vezes maior no teor da matéria orgânica acumulada, com uma proporção semelhante de $\mathrm{C}: \mathrm{N}$; b) a adição de moléculas orgânicas de baixo peso molecular no solo, causou uma melhora no teor de umidade; c) os locais que receberam a deposição, mostraram aumento significativo nos teores de lipídeos e açúcares; d) observou-se decréscimo no tamanho molecular dos ácidos húmicos e um crescimento nos ácidos flúvicos, ricos em polissacarídios.

A aplicação de resíduos com altas concentrações de N, P e K (40$230 \mathrm{~g} \mathrm{~m}^{-3}, 6-35 \mathrm{~g} \mathrm{~m}^{-3}, 20-120 \mathrm{~g} \mathrm{~m}^{-3}$, respectivamente), baixa concentração de metais pesados e de outros compostos tóxicos, foi efetuada por Russel et al. (1991), através da deposição de resíduos proveniente do processamento de carnes. A aplicação de doses acima das necessidades das plantas, resultou em aumento da concentração do Norgânico, do $\mathrm{N}$-nitrico, do fósforo, do sódio e do potássio na matéria seca da planta, chegando o $\mathrm{N}$-nitrico a atingir níveis tóxicos para os ruminantes. O excesso de fósforo aplicado ao solo, precipitou-se como fosfato e o excesso de $\mathrm{N}$ foi parcialmente desnitrificado. Os locais da pastagem que receberam o equivalente a $1200 \mathrm{~kg}$ de $\mathrm{N}^{-1}$ anualmente, demonstraram que a desnitrificação gerou perdas em média $4,5 \%$ sobre o que foi aplicado, enquanto que nos locais explorados por silvicultura, recebendo $715 \mathrm{~kg}$ de $\mathrm{N} \mathrm{ha}^{-1}$ anualmente, as perdas sobem para $27 \%$. Alertam os autores que a concentração 
de sódio no efluente poderia prejudicar o solo, o que necessitaria de um monitoramento constante e rigoroso.

A população aumenta constantemente. Os grandes e médios centros urbanos produzem taxas cada vez maiores de poluição, têm que suportar e fornecer condições mínimas de vida e, em decorrência, o acréscimo na produção de resíduos atinge niveis alarmantes. Barker \& Youmg (1985) irrigaram durante 20 anos, uma plantação antiga na parte central da Pensilvania, com $5 \mathrm{~mm}$ semana $^{-1}$ de resíduos municipais tratados. A eficiência do sistema de tratamento no solo para remover contaminantes da água do solo, foi monitorada ao longo deste período, considerando-se particularmente nitratos e metais pesados. Os resultados indicaram que o resíduo após passar os $120 \mathrm{~mm}$ de profundidade do solo, não mais contaminava o lençol e que a qualidade da água era similar a potável. Em 1982, amostras retiradas da parte aérea das árvores, da vegetação arbustiva e do solo, demonstraram a não contaminação por elementos metálicos.

Trabalho similar foi feito por Handley \& Ekern (1984) em grama irrigada por resíduos domésticos, onde mostraram excelentes respostas para a deposição de grandes quantidades de água, com remoção efetiva de $\mathrm{N}$ e alta produção de forragem. $\mathrm{A}$ água, o $\mathrm{N}$ e o restos de biomassa num período superior a 17 meses, foram medidos em oito lisímetros de percolação sob uma taxa de irrigação de $98 \mathrm{~mm} \mathrm{dia}^{-1}$, por 5 dias semana $^{-1}$, com evapotranspiração média de $4,6 \mathrm{~mm} \mathrm{dia}^{-1}$. Efetuando-se aplicações de $\mathrm{N}$ correspondentes de 130 a $2600 \mathrm{~kg} \mathrm{ha}^{-1}$, obteve-se os seguintes resultados: $79 \%$ do $\mathrm{N}$ aplicado, ficou contido na grama; $3 \%$ percolou e menos de $28 \%$ foi desnitrificado; os níveis de $\mathrm{N}$-nitrico permaneceu abaixo de $10 \mathrm{mg} \mathrm{dm}^{-3}$, que é o máximo recomendável para água potável; a produtividade acusou uma média de $110 \mathrm{Mg} \mathrm{ha}^{-1}$ de peso seco; o máximo calculado de proteína bruta foi $13 \%$ e o nível de $\mathrm{N}$-nitrico não excedeu $0,1 \%$.

As análises microbiológicas passam a ter papel preponderante nestes estudos, e as avaliações de sua população, aumentando ou diminuindo, podem dar bom direcionamento para os resultados obtidos. $\mathrm{O}$ uso de resíduos, pode resultar na contaminação do meio, onde o processo se desenvolve, e isto ocorre neste caso 
necessariamente no solo. Este componente ativo e participante de toda e qualquer paisagem, representa o meio de desenvolvimento de vários e incontáveis tipos de vida, possui um ambiente permanente de reações e processos químicos, físicos e, principalmente, biológicos que atuam, transformam, modificam e condicionam a vida. Suas propriedades permitem, ou favorecem, os processos atuantes de maneira a obter-se um sistema de equilíbrio tal que, mesmo com diferentes tipos e formas de interferências, a interação da microbiota com o ecossistema garante este equilíbrio, restaurando-o ou restabelecendo-o. Uma das formas de degradação do solo é a interferência neste processo e, na maioria dos casos, de maneira negativa atuando neste equilibrio biológico. O que deveria ocorrer seria o direcionamento das interferências de modo a facilitar os processos e enriquecer o meio para que as reações, provenientes até de possíveis agressões, encerrem as soluções desejáveis à manutenção deste equilibrio (Aloisi, 1995).

Por tudo isto, o melhor, senão o maior, indicador e parâmetro de controle que vai atuar no processo de aplicação dos resíduos é, sem dúvida alguma, a atividade microbiana. Sua análise e determinações, indicam a viabilidade ou não da aplicação dos resíduos. Assim procederam Asha \& Dutta (1990) que, estudaram diferentes tratamentos de destilaria, tratados e diluídos, e misturados na proporção de 1:1 com resíduos domésticos, para a avaliação da população de bactérias, fungos, actinomicetos e bactérias fixadoras de N. Os resultados obtidos demonstraram que: a) a água residual sem tratamento diminui a população de bactérias, fungos e actinomicetos; b) o crescimento das taxas de Rizobium e Azotobacter foi também reduzido após a aplicação da mesma água; c) o efeito tóxico deste tipo de resíduo foi minimizado quando misturado com água de tanque estabilizador na proporção de $1: 1$; d) houve aumento da população de todos os microorganismos e; e) a água proveniente da destilaria mostrou-se tóxica para os microrganismos pois ,quando colocada em plantas de soja, não houve nodulações.

Seaker (1991) aplicou lodo da cidade de Filadélfia na proporção de 138 a $145 \mathrm{Mg} \mathrm{ha}^{-1}$ como fertilizante, em solo situado na superfície de uma mina, por período de doze anos. Retirando amostras de 49 locais determinou os teores de $\mathrm{Zn}, \mathrm{Cu}, \mathrm{Pb}$ e $\mathrm{Ca}$, no solo, na água infiltrada, na água do lençol freático e na vegetação antes e posteriores a 
aplicação. Os resultados indicaram que os metais eram mais retidos nas camadas aradas onde o lodo foi incorporado, com evidências de pequeno acréscimo na concentração de metais na profundidade de 15 a $30 \mathrm{~cm}$. A água infiltrada e a qualidade do solo não foram afetadas pela aplicação e a concentração de metais nas folhas estavam dentro dos teores de tolerância para a cultura agronômica e dieta de animais domésticos. O autor concluiu que este tipo de deposição com lodo contendo concentrações de metais de baixa a média, não causa ameaça ao solo.

Uma concordância com este tipo de afirmação foi a pronunciada por Turtura \& Morselli (1991) que preconizam a utilização de lodo de esgoto na agricultura por apresentar as vantagens de que os nutrientes e os microorganismos incorporados ficam disponíveis às plantas e por ser mais compatível com a legislação ambiental existente. Contudo, afirmam eles, que a adequação do sistema depende da natureza do lodo, da água de esgoto original contida e do tratamento aplicado a esta. Assinalam que o perigo principal é o acúmulo de substâncias tóxicas e a presença de microorganismos patogênicos no solo, e que o risco será menor e mais reduzido com a implementação e aplicação de normas mais severas para obtenção da qualidade do esgoto das regiões envolvidas.

Em Yokayama, no Japão, Noguchi \& Ito (1992) desenvolveram meios para a secagem e granulação de lodo sintetizado, que tem sido produzido $\mathrm{e}$ comercializado como fertilizante, desde 1977. Paralelamente a esta atividade, pesquisas tem sido desenvolvidas sobre o uso continuo de fertilizantes de lodo, analisando-se o valor dos nutrientes e a influência dos metais pesados. Quatro tipos de fertilizantes e oito culturas foram utilizadas, e os resultados mostraram que o fertilizante de lodo tem o mesmo teor de nutrientes que o fertilizante orgânico, e que há uma mínima transferência dos metais pesados para a cultura, o que permite então, sua utilização continuamente, por um longo período.

A colocação de cinzas no solo na tentativa de se dispor de resíduos de caldeiras, é uma prática normal em indústrias que operam com a produção de energia via vapor. Este fato levou Klippel et al. (1983) a tentarem analisar desse resíduo, obtido em 
indústria de cromação, acrescido de outro gerado no mesmo local. Assim, experiências de laboratório e em condições de campo, mostraram a existência de dois mecanismos de prevenção da contaminação em profundidade (no lençol freático), por cromados tóxicos: adsorção de cromados lixiviados na interface cinza - solo, e redução do cromo hexavalente para trivalente por precipitação de ferro solúvel.

Hartz et al. (1984) estudaram um sistema de disposição de cinza vulcânica no solo, no intuito de minimizar a lixiviação de contaminantes produzidos por lixo industrial. Concluíram, que duas situações foram atingidas: a) a presença de cinza vulcânica ajuda na redução da lixiviação química, na demanda de oxigênio, e nas concentrações de $\mathrm{B}, \mathrm{Fe}, \mathrm{Cl}$ e $\mathrm{Zn}$, mas pode, entretanto, aumentar a lixiviação de selênio, cobre, cromo e arsênio; b) a separação de metais pesados com ferro hidratado e óxido de magnésio pode promover satisfatoriamente o pré-tratamento, enquanto diminui a produção de resíduos poluentes.

Procedendo a disposição de restos, provenientes da destilação e do extrato da polpa de beterraba, Drysdale (1985) mostrou, em resultados preliminares, que ocorrem ganhos e perdas na produção de pastagem, conforme a quantidade de nutrientes contidos no resíduo, no número de aplicações considerando-se ou não os teores requeridos pela planta. Afirma que, efetuando-se uma irrigação excessiva do resíduo, ocorre sérias reduções no crescimento da graminea. Trabalhando em pastagens na Nova Zelândia, o autor relata que a aplicação deste resíduo estimula a taxa de crescimento da pastagem, e que nenhum problema foi verificado quando esta disposição é feita considerando-se os teores exigidos pela planta, mas aconselha uma complementação potássica para atingir-se o equilibrio entre o $\mathrm{K}$ e N.

Beyer et al. (1992), utilizando borras secundárias em área de solo arado, os autores conduziram experimentos que revelaram: a) não foi constatada nenhuma degeneração no solo, mas também não se verificou nenhuma melhora no crescimento das plantas; b) não foi constatada acumulação de metais pesados no solo e na planta; c) não houve risco para o solo ou planta, porque os componentes halogênicos de compostos orgânicos estão presentes em níveis não comprometedores; d) o carbonato contido na 
borra dificultou o prognóstico do efeito do $\mathrm{pH}$ e; e) ocorreu fixação de $\mathrm{N}$ no solo durante a decomposição da borra; que é pobre no elemento. Concluiram que a aplicação de borra secundária no solo é perfeitamente possível no futuro desde que a indústria padronize o conteudo de carbonato no resíduo, de maneira que este teor exista para evitar a deficiência de micronutrientes.

\subsection{Metais pesados}

Os metais pesados, definidos por Passow et al. (1961), são aqueles metais que possuem densidade maior que 5, e incluem aproximadamente 40 elementos. Sua característica comum, em relação a vida biológica, é que em quantidade excessivas eles são tóxicos e podem causar a morte da maioria dos organismos vivos.

O termo metal pesado, que se encontra incorporado à bibliografia científica, é geralmente usado para os elementos: titânio, vanádio, cromo, ferro, níquel, zinco, arsênio, cobre, manganês, cobalto, bário, nióbio, prata, cádmio, estanho, mercúrio e chumbo (Jardim, 1983).

É dificil definir na agricultura que os metais pesados são prejudiciais a vida biológica. Qualquer elemento na natureza em concentração excessiva pode ser prejudicial a vida. Dentre os minerais definidos como metais pesados, alguns são nutrientes para as plantas e para os animais, e essenciais para o desenvolvimento da vida. Segundo Malavolta (1980) os elementos minerais poderiam ser convencionalmente definidos como essenciais, úteis e tóxicos, porém nem todo elemento tóxico é metal pesado, mas mesmo assim, em condições adequadas, baixas concentrações de um elemento considerado tóxico pode ser favoráveis ou estimulantes ao desenvolvimento dos seres vivos. Nesta convenção, os elementos considerados tóxicos as plantas e que não são essenciälmente todos metais pesados são: bromo, cádmio, chumbo, cromo, flúor, iodo, mercúrio, níquel, selênio e alumínio. Cobre, zinco, ferro e manganês são nutrientes enquadrados na lista dos metais pesados, porém sua biodisponibilidade no solo e concentração em plantas e alimentos é que limita a sua toxidez nas culturas agrícolas. 
A toxicidade dos metais pesados no solo podem ocorrer sob diversas circunstâncias. Dentre elas, tem-se a ocorrência natural como resultado de processos geológicos e da ação de intempéries na formação do solo, como também pela ação do homem, como acontece quando da operação de mineração, que resulta na disposição de escórias que constituem um substrato com alta concentração de metais (Epstein, 1975).

Paises do mundo todo vem procurando controlar os niveis de metais pesados no solo e nos resíduos, normas para utilização agrícola de lodos de tratamento biológico, compostos de lixo, resíduos e efluentes industriais vem sendo estabelecidas assim como niveis tolerados de metais no solo. A Tabela 1 mostra os valores de matais pesados tolerados no lodo e nos solos agricolas de dois paises europeus (Rogalla, 1998)

Tabela 1. Teor limite de metais pesados nos lodos e nos solos agrícolas de dois países europeus

\begin{tabular}{|c|c|c|c|c|}
\hline \multirow[b]{2}{*}{$\begin{array}{l}\text { Metais } \\
\text { Pesados }\end{array}$} & \multicolumn{2}{|c|}{ Holanda } & \multicolumn{2}{|c|}{ Noruega } \\
\hline & $\begin{array}{c}\text { lodos } \\
\text { mg kg } \\
\text { (base seca) }\end{array}$ & $\begin{array}{c}\text { solos } \\
\mathrm{mg} \mathrm{kg}^{-1} \text { seco }\end{array}$ & $\begin{array}{c}\text { lodos } \\
\mathrm{mg} \mathrm{kg}^{-1} \\
\text { (base seca) }\end{array}$ & $\begin{array}{c}\text { solos } \\
\mathrm{mg} \mathrm{kg} \mathrm{kg}^{-1} \text { seco }\end{array}$ \\
\hline As & - & - & 15,0 & 29,0 \\
\hline $\mathrm{Cd}$ & 5,0 & 0,8 & 1,3 & 0,8 \\
\hline $\mathrm{Cr}$ & 500,0 & 75,0 & 75,0 & 100,0 \\
\hline $\mathrm{Cu}$ & 600,0 & 50,0 & 75,0 & 36,0 \\
\hline $\mathrm{Pb}$ & 500,0 & 50,0 & 100,0 & 85,0 \\
\hline $\mathrm{Hg}$ & 5,0 & 0,8 & 0,8 & 0,3 \\
\hline $\mathrm{Ni}$ & 80,0 & 50,0 & 30,0 & 35,0 \\
\hline $\mathrm{Zn}$ & 2000,0 & 200,0 & 300,0 & 140,0 \\
\hline $\mathrm{Co}$ & 60,0 & 25,0 & - & - \\
\hline
\end{tabular}

Fonte: Rogala (1998)

Nos Estados Unidos, novas normas que regulamentam a concentração limite de dez metais pesados em resíduos destinados para uso agrícola, foram aprovadas pelo órgão de controle ambiental (EPA-Environmental Protection Agency). Essas novas quantidades permissiveis aparecem na Tabela 2, onde também aparecem as doses máximas de metais que podem ser adicionada anualmente e a quantidade máxima 
permissivel em solos agrícolas. Ressalte-se que, não foram mencionados os critérios para o estabelecimento destes parâmetros (Wallace \& Wallace, 1994).

A formação dos metais pesados no solo e as características dos microorganismos, podem influir na disponibilidade destes elementos. Estes processos envolvem reações de absorção/dessorção, complexação/oxi-redução, pH, força iônica, quantidade de adsorventes, etc. (Allaway, 1968; Lindsay, 1979; Kabata \& Pendias, 1984).

Tabela 2. Parâmetros para o uso de lodo de esgoto e outros residuos em termos de dez metais pesados denominados poluentes pela EPA.

\begin{tabular}{|c|c|c|c|c|}
\hline $\begin{array}{l}\text { Metais } \\
\text { Pesados }\end{array}$ & $\begin{array}{c}\text { Concentração } \\
\text { máxima permissivel } \\
\text { nos resíduos }{ }^{(1)} \\
\mathrm{mg} \mathrm{kg}^{-1} \text { (base seca) }\end{array}$ & $\begin{array}{c}\text { Concentração } \\
\text { maxima permissivel } \\
\text { em solos }{ }^{(2)} \\
\mathrm{Mg} \mathrm{dm}^{-3}\end{array}$ & $\begin{array}{c}\text { Residuo } \\
\text { considerado } \\
\text { "limpo"(3) } \\
\mathrm{mg} \mathrm{kg}^{-1}\end{array}$ & $\begin{array}{c}\text { Taxa anual máxima } \\
\text { de aplicação no } \\
\text { solo }^{(4)} \\
\mathrm{kg} \mathrm{ha}^{-1}\end{array}$ \\
\hline As & 75 & 21 & 41 & 2,0 \\
\hline $\mathrm{Cd}$ & 85 & 20 & 39 & 1,9 \\
\hline $\mathrm{Cr}$ & 3000 & 1500 & 1200 & 150,0 \\
\hline $\mathrm{Cu}$ & 4300 & 750 & 1500 & 75,0 \\
\hline $\mathrm{Pb}$ & 840 & 150 & 300 & 15,0 \\
\hline $\mathrm{Hg}$ & 57 & 9 & 17 & 0,9 \\
\hline Mo & 75 & 9 & 18 & 0,9 \\
\hline $\mathrm{Ni}$ & 420 & 210 & 420 & 21,0 \\
\hline $\mathrm{Se}$ & 100 & 50 & 36 & 5,0 \\
\hline $\mathrm{Zn}$ & 7500 & 1400 & 2800 & 140,0 \\
\hline
\end{tabular}

1) Considerando o uso agrícola.

2) Considerando uma única ou várias aplicações do residuo

3) Niveis de metais inferiores aos relacionados caracterizam o chamado residuo "limpo"

4) Utilizado quando a concentração dos vários metais presentes exceder o limite estabelecido no residuo classificado como "limpo".

Fonte: Wallace \& Wallace (1994).

Os metais pesados caracterizados por maior mobilidade no solo, estão nas formas trocáveis e carbonatos, e os de menor mobilidade estão ligados as frações de óxidos de Fe e de Mn e as frações orgânicas (Cañadas et al., 1986). A absorção dos metais pesados pelas plantas, depende da espécie e de sua concentração disponivel no solo (Bingham et al., 1975). Para Alloway (1990), Pb e Cu são os metais pesados mais fortemente adsorvidos e, $\mathrm{Ni}$ e $\mathrm{Cd}$ são os mais fracamente adsorvidos. 
É comum a afinidade de $\mathrm{Cd}$ com $\mathrm{Zn}$. Cd forma complexos com hidróxidos, carbonatos e cloretos. A atividade do $\mathrm{Cd}$ é afetada pelo aumento de $\mathrm{pH}$ e sua disponibilidade no solo geralmente excede $0,5 \mathrm{mg} \mathrm{dm}^{-3}$ (Kitashi \& Yamane, 1981).

O Cr é quantitativamente precipitado quando o $\mathrm{pH}$ do solo ultrapassa 5,5, é muito instável, mobilizando-se em solos ácidos sendo encontrado na solução do solo até $120 \mathrm{mg} \mathrm{dm}^{-3}$ (Bartlett \& Kimble, 1976). A concentração de $\mathrm{Cr}$ no solo, segundo Lyndsay (1979), é de até $200 \mathrm{mg} \mathrm{dm}^{-3}$, sendo sua média na superficie do solo $50 \mathrm{mg}$ $\mathrm{dm}^{-3}$. O Ti, segundo Hutton (1977), dificilmente causa problemas para o crescimento e desenvolvimento das plantas. O autor afirma que a concentração de Ti varia de 300 e $1400 \mathrm{mg} \mathrm{dm}^{-3}$ na superficie do solo.

Chaudry et al. (1977), em estudo com metais pesados absorvidos pelas plantas, afirmaram que o Ba pode ser facilmente mobilizado e adsorvido pelas argilas. Este metal também precipita-se como carbonato e sulfato na solução do solo, daí sua característica de não ser muito móvel. O Ba apresenta característica de moderada toxicidade e sua concentração na solução do solo chega até $220 \mathrm{mg} \mathrm{dm}^{-3}$.

Estudando a poluição dos solos agrícolas ingleses, Davies \& Roberts (1978) afirmam que o limite de chumbo trocável no solo em termos de ambiente é de 70 $\mathrm{mg} \mathrm{dm}{ }^{-3}$, e que a variação nestes solos é de 0,1 a $10 \mathrm{mg} \mathrm{dm}^{-3}$.

Muitos aspectos da química dos metais pesados no solo estão relacionados com a formação de complexos com a matéria orgânica. Enquanto, os metais monovalentes $\left(\mathrm{Na}^{+}, \mathrm{K}^{+}\right.$e outros) são retidos principalmente como simples cátions trocáveis, através da formação de sais com os grupos - $\mathrm{COOH}$; os cátions polivalentes $\left(\mathrm{Cu}^{2+}, \mathrm{Zn}^{2+}, \mathrm{Mn}^{2+}, \mathrm{Co}^{2+} \mathrm{e}\right.$ outros) têm o potencial de formar ligações coordenadas com moléculas orgânicas. A constante de estabilidade dos complexos ou quelados com íons metálicos é determinada por diversos fatores, incluindo o número de átomos que forma a ligação com o ion metálico, o número de anéis que são formados, a natureza e a concentração dos íons metálicos e o valor do $\mathrm{pH}$. A constante de estabilidade dos quelados obedece a seguinte ordem: $\mathrm{Cu}^{2+}>\mathrm{Ni}^{2+}>\mathrm{Co}^{2+}>\mathrm{Zn}^{2+}>\mathrm{Fe}^{2+}>\mathrm{Mn}^{2+}$ (Stevenson, 1982). A concentração de um íon metálico pode ser reduzida a um nível não 
tóxico através da complexação, isto ocorre, quando o complexo orgânico metálico tem baixa solubilidade, ou seja alta estabilidade, tal como complexos de ácido húmico e outros componentes da matéria orgânica de alto peso molecular, (Stevenson, 1982).

A possibilidade dos metais pesados virem a se movimentar no solo depende muito de suas solubilidades. A maioria dos pesquisadores reconhecem que esses metais são moderadamente solúveis, e ocorrem predominantemente no estado sorvido ou como parte de compostos orgânicos ou inorgânicos. Devido a sua baixa solubilidade, o movimento dos metais pesados no solo tem sido considerado mínimo (Dowdy \& Volk, 1984). Entretanto, Jardim (1983) ressaltou que a ocorrência de solos ácidos favorece a solubilizaçâo dos metais pesados, promovendo desta forma uma maior mobilidade.

Por sua vez, esta mobilidade, de acordo com Dowdy \& Volk, (1984), é fortemente afetada pelos teores de matéria orgânica e de hidróxidos, bem como os locais de adsorção iônica. Segundo eles, os metais pesados apresentam orbitais vazios, que são freqüentemente quelados ou complexados com materiais orgânicos do solo. Estes compostos quelados podem ser mais solúveis que os precipitados inorgànicos. Há, observações de que a adsorção de cádmio e de chumbo, ligados a matéria orgânica, aumenta com a elevação do pH (Gerritse \& Driel, 1984).

Ao estudar o movimento de elementos e sais nos locais de disposiçâo de xisto retortado, Stark \& Redente (1986) observaram que o molibdênio apresenta fraca redistribuição dentro dos perfis solo-xisto retortado, tendo sua lixiviação, aparentemente, pouco efeito na redução de sua concentração sob condição de campo. Enquanto que, elementos com cádmio, chumbo, cobre, ferro, manganês, niquel e zinco permaneceram na camada de xisto retortado.

A constatação dos íons metálicos do solo, que são disponiveis às plantas, $\mathrm{e}$ consequentemente sua quantificação está na dependência do método utilizado na extração dos mesmos (Porto, 1986)

As formas como ocorrem os metais no solo dificultam a quantificaçâo dos mesmos; mas apesar disto, segundo Antonovics et al. (1971) o teor total de metais no substrato parece refletir a quantidade disponivel às plantas, não havendo evidència de que 
os teores solúveis em água ou ácido são semelhantes. Entretanto, Porto (1986) obteve métodos de extraçâo mais efetivos para cádmio, chumbo, cobre e níquel com solução de $\mathrm{HNO}_{3}, 0,1 \mathrm{~N}$ e para o molibdênio com acetado de amônio. De acordo com Malavolta (1976), a determinação da disponibilidade do cobalto para as plantas pode ser realizada com solução de ácido acético $0,5 \mathrm{~N}$, ou com solução de acetato de amônio normal e neutro, sendo que a concentração normal encontrada para o ácido acético $0,5 \mathrm{~N}$ é de 0,1 a $1 \mathrm{mg} \mathrm{kg}^{-1}$; enquanto que com acetato de amônio obteve-se valores menores, já para o niquel a determinação pode ser realizada com acetato de amônio normal e neutro.

\subsection{Caracterização do xisto retortado}

O xisto trata-se de uma rocha essencialmente silto-argilosa, com conteúdo apreciável de matéria orgânica, que sob aquecimento, pode produzir óleo, gás e enxofie. As rochas características são, convenientemente, denominadas "folhelhos oleigenos". São duras, escuras (negras, negras-acastanhada ou castanhas), meteorizando-se em placas muito finas. São rochas constituidas por material orgânico $(14-28 \%)$ e fração clástica. A fração clástica é formada principalmente por quartzo de grãos muito finos e quantidades variáveis de sericita, moscovita, clorita, argilo-mineral (ilita dominante), plagioclásio. Um ou mais destes minerais pode faltar. Como constituinte varietal destaca-se a pirita ( $5 \%$ a $12 \%$ em volume); turmalina, em minúsculos grãos rolados, é um assessório comum (Grossi Sad et al., 1984). O xisto originou-se de restos de vegetais e animais acumulados no fundo de grandes corpos d'água estagnada, onde encontra-se misturado com argila e areia. Esta mistura no processo de formação foi comprimida numa marga sob temperatura e pressão insuficiente para convertê-lo em óleo (Davis, 1978)

Os maiores depósitos de óleo de xisto estão localizados nos Estados Unidos da América, sendo o da formação Green River no Colorado, Utah e Wyoming o mais conhecido (Davis, 1978). No entanto, somente no Brasil, na Estônia e na China (Manchúria) encontram-se em atividades unidades para o aproveitamento dos recursos de 
xisto, para a produção de óleo ou produção de energia através de termoeléctricas (Neiva. 1987).

O Brasil apresenta a segunda maior reserva de folhelhos oleigenos (xisto) do mundo, sendo que os depósitos da formação Iratí constituem-se na maior reserva brasileira de combustíveis e produtos sulfurosos (Prien, 1975; Bigarella, 1975).

No Paraná ocorre duas camadas distintas de folhelhos pirobetuminoso separadas por camadas de folhelhos não betuminosos de rochas calcárias. Tais folhelhos caracterizam-se por apresentarem, do norte para o sul, um aumento de espessura em detrimento das rochas calcárias. Em São Mateus do Sul, as camadas superiores e inferiores de folhelho pirobetuminoso possuem respectivamente 6,5 e 3,2 metros de espessura (Bigarella, 1975).

A Tabela 3 apresenta os resultados da análise química realizada em uma amostra de xisto retortado obtida na UPI/PETROBRÁS. A denominação de xisto retortado é dada ao xisto que, já passou pelo processo de extração do gás. óleo e enxofre. Estes resultados são apresentados em teor percentual do elemento e do óxido correspondente (forma usual de representação da composição química de rochas). Nessa tabela estão também relacionados os valores de análise química elementar e de óxidos equivalentes do xisto calcinado. Nesse material, foram eliminados, inteiramente, a água de composição das argilas, carbono (residual), carbonatos e enxofre como sulfeto (grande parte da pirita é ustulada, embora parte seja oxidada a sulfato anidro) (Fonseca, 1983; Fonseca et al., 1984a e 1984b).

Após estas considerações, observa-se que o principal problema, que limita o desenvolvimento da indústria do xisto, é a disposição do xisto retortado no ambiente, de modo a não afetá-lo ecologicamente (Gratt, 1985; Stark \& Redente, 1990). A alta alcalinidade deste residuo, valores de $\mathrm{pH}$ ao redor de 12 , é um dos fatores que impedem de maneira severa revegetação direta (Reddy \& Lindsay, 1986). 
Tabela 3. Composição química, elementar e de óxidos equivalentes, do xisto retortado, formação Irati, na UPI/PETROBRAS, e do respectivo xisto calcinado.

\begin{tabular}{|c|c|c|c|c|c|}
\hline \multirow[b]{2}{*}{ Elemento } & \multicolumn{2}{|c|}{ Composiçâo $\mathrm{g} \mathrm{kg}^{-1}$} & \multirow[b]{2}{*}{$\begin{array}{c}\text { Equivalente } \\
\text { em Óxido }\end{array}$} & \multicolumn{2}{|c|}{ Composição g $\mathrm{kg}^{-1}$} \\
\hline & $\begin{array}{c}\text { Xisto } \\
\text { retortado }\end{array}$ & $\begin{array}{c}\text { Xisto } \\
\text { Calcinado }\end{array}$ & & $\begin{array}{l}\text { Xisto } \\
\text { retortado }\end{array}$ & $\begin{array}{c}\text { Xisto } \\
\text { Calcinado }\end{array}$ \\
\hline $\mathrm{Si}$ & 270,0 & 310,0 & $\overline{\mathrm{SiO}_{2}}$ & 574,0 & 673,0 \\
\hline $\mathrm{Al}$ & 64,0 & 75,0 & $\mathrm{Al}_{2} \mathrm{O}_{3}$ & 121,0 & 142,0 \\
\hline $\mathrm{Fe}$ & 58,0 & 68,0 & $\mathrm{Fe}_{2} \mathrm{O}_{3}$ & 83,0 & 97,0 \\
\hline $\mathrm{Ti}$ & 3,6 & 04,2 & $\mathrm{TiO}_{2}$ & 6,0 & 7,0 \\
\hline $\mathrm{Mn}$ & 0,5 & 0,6 & $\mathrm{MnO}$ & 0,7 & 0,8 \\
\hline $\mathrm{Ca}$ & 11,0 & 13,0 & $\mathrm{CaO}$ & 15,0 & 18,0 \\
\hline $\mathrm{Mg}$ & 10,0 & 11,0 & $\mathrm{MgO}$ & 16,0 & 19,0 \\
\hline $\mathrm{Na}$ & 11,0 & 13,0 & $\mathrm{Na}_{2} \mathrm{O}$ & 15,0 & 18,0 \\
\hline K & 17,0 & 19,0 & $\mathrm{~K}_{2} \mathrm{O}$ & 20,0 & 23,0 \\
\hline$P$ & 1.8 & 2,2 & $\mathrm{P}_{2} \mathrm{O}_{5}$ & 4,3 & 5,0 \\
\hline S & 37,0 & n.d. & perda ao fogo & 147,0 & - \\
\hline \multirow[t]{2}{*}{$\mathrm{C}$} & 38,0 & - & & & \\
\hline & & Total & & 1002,0 & 1002,8 \\
\hline
\end{tabular}

Fonte: Fonseca (1983).

Outros problemas que podem ser encontrados com o reaproveitamento do xisto retortado estão geralmente associados aos teores de metais pesados e sais, que podem migrar para a superficie do solo e/ou concentrar-se na zona radicular, inibindo o restabelecimento das plantas (Fransway \& Wagenet, 1981; Stark \& Redente, 1986). Posteriormente, Patterson et al. (1988) viriam a reafirmar que a maior parte dos metais pesados permaneciam substancialmente, se não completamente, no xisto retortado.

Além dos metais pesados e os sais poderem mover-se para fora da camada de xisto, contaminando o abastecimento de água do solo e impedindo o crescimento e o estabelecimento de plantas, podendo provocar a ocorrência de plantas que apresentam altas concentrações deste elemento, tóxicos aos herbivoros. As plantas que crescem sobre locais de disposição, podem absorver estes metais, incorpora-los dentro da folhagem, e deposita-los na superficie do solo. Este processo de bombeamento biológico tem o potencial de aumentar substancialmente as concentrações de metais pesados na superficie do solo (Stark \& Redente, 1990). 
Apesar de toda esta preocupação com a presença de metais pesados e sais no xisto retortado, observa-se cue dependendo do elemento considerado e do método de utilização, pode haver ou não problemas de contaminação

Alguns trabalhos buscando o uso adequado do xisto são citados. Kilkelly \& Lindsay (1982) verificaram que as espécies de arbusto Atriplex canesces, que cresceram sobre o xisto retortado de USBM, continham teores médios de molibdènio (28 $\left.\mathrm{mg} \mathrm{kg}^{-1}\right)$ e teores baixos a moderado de cobre $(4,8-6,8 \mathrm{mg} \mathrm{kg})$, sendo que esta combinação fez com que esias espécies fossem inaceitáveis como forragem para os ruminantes. Também, constataram que Atriplex canesces acumulava maiores teores de molibdênio do que a gramínea Agropyron smithii, atribuindo tal fato ao enraizamento mais profundo do arbusto.

Ao estudarem a concentração de alguns metais pesados nas plantas, que cresciam sobre o xisto retortado coberto com solo, Schwab et al. (1983) verificaram que as concentrações de cobalto, cádmio e chumbo dessas plantas estavam abaixo do limite de deteç̧ão analítica, e que estes elementos não se acumulavam em níveis que fossem perigosos aos animais que pastoreiam. Com relação as concentrações de niquel, cobre e cromo nas plantas, estas concentrações oscilaram respectivamente em torno de 1,53-8,60 $\mathrm{mg} \mathrm{kg}$; $3,43-11,80 \mathrm{mg} \mathrm{kg}^{-1}$ e 0,43-4,80 $\mathrm{mg} \mathrm{kg}^{-1}$, não sendo significativamente diferentes das concentrações obtidas no tratamento controle. Concluiram também que as concentrações de níquel na planta foram muito baixas para serem consideradas uma preocupação ambiental. Quanto ao molibdênio, verificaram que todas as plantas, que se desenvolveram no substrato que apresentava $30 \mathrm{~cm}$ de solo sobre o xisto retortado, apresentaram concentrações de Mo maior que a concentração crítica $\left(2 \mathrm{mg} \mathrm{kg}^{-1}\right)$, assim os ruminantes que se nutrissem de tais plantas poderiam apresentar molibdenose.

Stark \& Redente (1990) estudaram a absorção das plantas e a ciclagem dos metais pesados sobre as pilhas dispostas de xisto retortado. Constataram que a alta concentração de molibdênio na forragem parece constituir o maior perigo ambiental, associado com a absorção de metais pesados pelas plantas. Porém, observaram que os tratamentos que apresentam 60 e $90 \mathrm{~cm}$ de solo sobre o xisto retortado, bem como o 
tratamento que apresentava uma barreira capilar rochosa de $30 \mathrm{~cm}$ eram eficazes em reduzir as concentrações destes elementos nas plantas.

\subsection{Caracterização da escória}

As escórias básicas săo subprodutos da produção de ferro gusa ou de aço. Minério de ferro, fundente e carvão são colocados no alto forno, onde a elevada temperatura promove a fusão destes materiais. A formação de uma escória básica de siderurgia depende da solubilização da cal, necessária para a neutralização da sílica e para combinar com o fósforo e o enxofre e, assim, manter o teor adequado de óxidos de ferro. Nas elevadas temperaturas dos altos fornos, o silício, o manganês e o fósforo sào oxidados no meio do metal líquido. Os óxidos de ferro, cal, magnésia e alumina também ajudam a formar a escória. A cal adicionada nos fornos varia de 80 a $150 \mathrm{~kg} \mathrm{t}^{-1} \mathrm{e}$, na decomposição do calcário o $\mathrm{CO}_{2}$ reage com o óxido de ferro formando o sesquióxido de ferro da escória. Na redução do ferro, o carbonato forma o óxido de cálcio que combina com a silica derretida, formando a escória (Firme, 1986).

Como a densidade da escória é menor do que a do ferro, há uma separação do material no interior do alto forno. Após a formação, a escória é retirada com facilidade, devido à sua viscosidade, ela flui por um canal de escoamento de onde é retirada e armazenada (Piau, 1995). A escória pode ser resfriada com injeção de ar, ou bruscamente com água, quando sai do alto forno ("quenching"), ou resfriada naturalmente nos pontos de armazenamento (Firme, 1986).

Geralmente o carvão vegetal é usado na obtenção do ferro gusa. Neste processo são obtidos $300 \mathrm{~kg}$ de escórias por tonelada de ferro gusa. Sessenta e seis por cento das escórias são obtidas dos altos fornos e o restante das aciárias. O revestimento dos altos fornos geralmente é feito de dolomita ou de magnésia. Estes refratários são de curta duração, enriquecendo a escória ao serem desgastados. A cal substitui os óxidos de ferro e de manganês nos silicatos, formando $\mathrm{CaO}, \mathrm{FeO}, \mathrm{SiO}_{2}$ e $\mathrm{CaFe}_{2} \mathrm{O}_{3}$. Nas 
siderúrgicas, definem a basicidade de uma escória pela relação de $\mathrm{CaO}: \mathrm{SiO}_{2}$ que oscila entre 2,3 a 3,0. Na prática, utiliza-se a coloração de uma escória como paràmetro de sua basicidade. As escórias básicas variam, do rosado ao chocolate, à medida em que aumenta o teor de ferro e manganês. Diversos elementos originários dos fundentes e das paredes do alto forno se combinam para formar a escória. A escória é essencialmente um silicato de cálcio. O material inerte do minério, dos fundentes e do coque, chegando às zonas mais quentes do alto forno $\left(1900^{\circ}\right)$, reagem entre si formando, principalmente, $\mathrm{CaSiO}_{3}, \mathrm{MgSiO}_{3}, \mathrm{Al}_{2} \mathrm{O}_{3} \cdot \mathrm{SiO}_{2}, \mathrm{MgCO}_{3} \mathrm{Al}_{2} \mathrm{O}_{3}$ e $\mathrm{CaCO}_{3} \cdot \mathrm{Al}_{2} \mathrm{O}_{3}$ (Wittaker ${ }^{1}$ (1955), citado por Piau, 1995).

O enxofre contido na escória, origina-se do carvão (coque), o $\mathrm{MnO}$ do minério de ferro e dos fundentes da escória e o $\mathrm{FeO}$ vem da redução incompleta do $\mathrm{Fe}_{2} \mathrm{O}_{3}$ do minério. As concentrą̧ões de $\mathrm{Zn}, \mathrm{Cu}, \mathrm{Ti}, \mathrm{Ba}, \mathrm{Mo}$, $\mathrm{Co}$ e outros metais, estào em proporções que dependem da afinidade química do elemento com o ferro, da temperatura do forno e de sua basicidade (Piau, 1991).

Além dos macronutrientes, são encontrados nas escórias básicas de siderurgia e nos calcários, micronutrientes e metais pesados (Piau, 1991). A importància dos micronutrientes para os vegetais, se eqüivale aos macronutrientes diferindo somente na quantidades (Malavolta, 1980).

O uso de escória de siderurgia em algumas culturas vem sendo relatadas por vários autores. White (1937) relata que desde 1916, já havia experimentos visando a comparaçầo de escórias de siderurgia com calcários e outros corretivos.

Em experimento com trevo vermelho, Naftel (1942), verificou altas produções no tratamento com escória de siderurgia, quando comparadas ao calcário calcítico e dolomítico. Este fato foi atribuído ao boro contido na escória.

Um importante fator na utilização das escórias de siderurgia, para o aumento de produção das culturas, é a maior disponibilidade de fósforo, pela adição dos

\footnotetext{
${ }^{1}$ WITTAKER. C. W. Blast furnace slag in agriculture pit and quarry. 1955. p. 139-50.
} 
silicatos. Taylor (1961); Obihara \& Russel (1972) e Smith \& Sanches (1980), citaram aumentos do teor de fósforo disponivel no solo pela adição de escórias de siderurgia.

A aplicação de escórias em solos com baixo $\mathrm{Si}$ disponivel (Fox et al., 1967; Elawad \& Green, 1979) diminuíram a toxidez de $\mathrm{Mn}$, aumentaram a resistência das plantas às doenças, o poder de oxidação das raizes do arroz e também, a disponibilidade de fósforo. Também é reportado por Fox et al. (1967) que a aplicação de escória em alguns oxisois, aumenta a solubilidade do fósforo, o valor de $\mathrm{pH}$, os teores de $\mathrm{Ca}$ e $\mathrm{Mg}$ trocáveis, e a adsorção de Si diminui a fixação de $\mathrm{P}$.

Anderson et al. (1987) aplicaram 0;2,5;5;10 e $20 \mathrm{Mg} \mathrm{ha}^{-1}$ de escória de siderurgia em solos da Florida, onde plantou-se arroz e, após a colheita, fez-se a rotação de cultura com cana-de-açúcar. A aplicação de $20 \mathrm{Mg} \mathrm{ha}^{-1}$ de escória aumentou en 39\% a produção de açúcar e em $50 \%$ a produção de cana durante três anos

Ross et al. (1974) obtiveram um aumento significativo, com a aplicação de $7,1 \mathrm{Mg} \mathrm{ha}^{-1}$ de silicato de cálcio, na produção de cana-de-açúcar em solos contendo baixos teores de $\mathrm{Si}$. Foram considerados baixos teores no solo, usando Mehlich como extrator, por volta de $77 \mathrm{mg} \mathrm{kg}^{-1}$ de Si. Em um experimento de 5 anos utilizando solos argilo-arenoso, Uhlen (1974) observou que a aplicação de $14 \mathrm{Mg} \mathrm{ha}^{-1}$ de silicato de cálcio foi responsável pelo aumento de produção de aveia nos três primeiros anos de produção, e que, o aumento foi maior do que quando aplicado somente o Ca na forma de hidróxido de cálcio. $\mathrm{O}$ teor de $\mathrm{Si}$ nas folhas foi consideravelmente aumentado com a aplicação do silicato. Não houve efeito significativo nos teores de $\mathrm{P}, \mathrm{K}, \mathrm{Ca}, \mathrm{Mg}$ e $\mathrm{B}$ nas folhas devido a aplicação de silicio.

Trabalhando com pastagens no norte da Espanha, Rodriguez et al. (1994) utilizaram uma escória de aciária com as dosagens $1,1,5,3,5$ e 7,5 $\mathrm{Mg} \mathrm{ha}^{-1}$ durante 3 anos. A Aplicação de escória aumentou linearmente o pH do solo, diminuindo a saturação de $\mathrm{Al}$. A aplicação de escórias de aciária aumentou a concentração de Ca, Mg e P no solo e nas pastagens, havendo uma diminuição na concentração de manganês. 


\subsection{Silício nos resíduos, no solo e nas plantas}

As escórias básicas de siderurgia são essencialmente silicatos de Ca e Mg. Porém, estes compostos silicatados trazem como impurezas vários micronutrientes como: $\mathrm{Fe}, \mathrm{Cu}, \mathrm{Zn}, \mathrm{Mo}, \mathrm{Co}, \mathrm{B}$ e Mn, contendo ainda um pequeno percentual de $\mathrm{P}, \mathrm{K}$ e S (Piau, 1991). O xisto retortado também contém apreciável quantidade de silicatos, além de carbono e outros elementos (Fonseca, 1983).

O silício geralmente não é considerado integrante do grupo de elementos essenciais ou funcionais para o crescimento das plantas. No entanto, o crescimento e a produtividade de muitas gramíneas (arroz, cana-de-açúcar, sorgo, milheto, aveia, trigo, milho, grama kikuyu, grama bermuda, etc.) e algumas espécies não gramíneas (alfafa, feijão, tomate, alface e repolho) têm mostrado aumentos de produtividade com o aumento da disponibilidade de Si para as plantas (Elawad \& Green, 1979).

Mesmo sabendo que o silício é um dos elementos mais abundantes na crosta terrestre, a quantidade de sílica nos solos varia amplamente, de acordo com a natureza do material de origem e de suas transformações, encontrado nas formas de minerais silicatados cristalinos, e minerais não cristalinos amorfos. A quantidade de sílica nos solos varia de menos de $10 \%$ a quase $100 \%$, porém, em algumas lateritas, é menor que 1\% (Sivarajasingham et al., 1962). Cultivos consecutivos, podem reduzir o nível deste elemento até que a adubação com silício, seja necessária para obtenção de máximas produções. Solos muito intemperizados e altamente lixiviados, ácidos, com baixos teores de silício trocável e baixa relação Silício/sesquióxidos, são apontados como sendo particularmente pobres em silício disponível para as plantas (Brady, 1990; International Rice Research Institute, 1978).

A sílica solúvel presente na solução do solo está principalmente na forma $\mathrm{H}_{4} \mathrm{SiO}_{4}$, indicada pelas constantes de ionização do ácido silicico, $\mathrm{pK}_{1}=9,8$ e $\mathrm{pK}_{2}=12$. No entanto, pode ocorrer também como sílica hidratada $\left(\mathrm{SiO}_{2} \cdot \mathrm{nH}_{2} \mathrm{O}\right)$, e como íon silicato $\left(\mathrm{H}_{3} \mathrm{SiO}_{4}\right)$ (Malavolta, 1976). Esta sílica dissolvida na solução do solo na forma de 
$\mathrm{H}_{4} \mathrm{SiO}_{4}$, ocorre em concentrações próximas ao equilibrio, podendo variar de 1-200 mg $\mathrm{dm}^{-\hat{*}}$ na solução (Hopps et al., 1977).

Os fatores de solo que influenciam a concentração de silica em solução são, de acordo com Raupach ${ }^{2}$, citado por McKeague \& Cline (1963), a textura, a composição mineralógica, o valor $\mathrm{pH}$ e a presença de determinados íons em solução.

O Si é disponível no solo no intervalo de $\mathrm{pH} 2$ a 9, quando sua concentração de $\mathrm{SiO}_{2}$ amorfa é de $2 \mathrm{mM}$ (Ponnamperuma, 1972). Sua disponibilidade às plantas decorre da sua dissolução no solo. A concentração de ácido silícico na solução do solo é essencialmente controlada pelo pH e depende da reação de adsorção dos sesquióxidos.

Elgawhary e Lindsay (1972) verificaram que a forma preferencial de silica em solução abaixo de $\mathrm{pH} 8$, é $\mathrm{H}_{4} \mathrm{SiO}_{4}$ e, que está em equilibrio com a sílica da fase sólida. A adição de compostos silicatados solúveis não eleva a concentração de $\mathrm{H}_{4} \mathrm{SiO}_{4}$ em solução, já que este passa rapidamente para a fase sólida; ao contrário as formas sólidas parcialmente solúveis promovem incrementos de $\mathrm{H}_{4} \mathrm{SiO}_{4}$ na solução. Os minerais silicatados do solo, que controlam a solubilidade da sílica são menos solúveis que a silica amorfa e mais solúveis que o quartzo.

Os minerais silicatados estão em equilibrio com o $\mathrm{H}_{4} \mathrm{SiO}_{4}$ em solução, e só se solubilizarão quando a concentração em solução se reduzir. No entanto, estando na forma molecular ou aniônica, a sílica apresenta tendência de lixiviação. Ficou caracterizado pelos resultados de Baker \& Scrivner (1985), que o processo de intemperismo é mais intenso na camada superficial dos solos, e que a concentração dos minerais mais intemperizados reduz-se com a profundidade e a dos menos intemperizados aumenta no mesmo sentido, com uma lixiviação mais intensa de Si que a de $\mathrm{Al}$. A concentração do $\mathrm{H}_{4} \mathrm{SiO}_{4}$ variou de $4 \mu \mathrm{g} \mathrm{m} \mathrm{dm}{ }^{-3}$ de Si no horizonte A para $18 \mu \mathrm{g} \mathrm{m} \mathrm{dm}$ de Si no horizonte $\mathrm{C}$ do solo estudado, provocada pelo deslocamento do equilibrio entre minerais menos intemperizados e a maior concentração de $\mathrm{H}_{4} \mathrm{SiO}_{4}$ em solução, lixiviada

\footnotetext{
${ }^{2}$ RAUPACH, M. C.S.I.R.O. (Australia) Soil Publ., 9, 1975. 35p.
} 
das camadas superiores. Pode-se, concluir por esses resultados, que a concentração de silica em solução será tanto maior, quanto for a quantidade de sílica da fase sólida. As reações de precipitação e dissolução do ácido silicico dissolvido na solução do solo dependem de sua concentração e da presença de óxidos de Fe e Al. Assim, o ácido silícico pode polimerizar-se, formando colóides silicatados quando a concentração de $\mathrm{SiO}_{2}$ for superior a $120 \mathrm{mg} \mathrm{kg}^{-1}$, à temperatura controlada e o $\mathrm{pH}$ da solução, próximo a neutralidade (McKeague \& Cline, 1963). Este mecanismo funciona como regulador da concentração de sílica em solução (Iler, 1979).

Outro processo responsável pelo controle da concentração de $\mathrm{H}_{4} \mathrm{SiO}_{4}$ é a adsorção. A adsorção específica de um ânion envolve a formação de um complexo de coordenação na superfĩcie dos óxidos de Fe e Al (Jones \& Handreck, 1967). McKeague $\&$ Cline (1963), verificaram que precipitados recentes dos hidróxidos de $\mathrm{Fe}, \mathrm{Al}, \mathrm{Ni}$ e Co são mais eficientes na remoção de sílica da solução, que a hematita e a gibsita. Os minerais silicatados dos solos, também adsorvem silicatos e fosfatos, porém em menor quantidade que os óxidos. A adsorção de sílica é uma reação dependente de $\mathrm{pH}$, sendo este o principal fator determinante da sua concentração em solução. Cotton e Wilkinson $(1962)^{3}$ citados por Hingston et al. (1972), afirmaram que os ácidos bórico e silícico, comportam-se como monobásicos, podendo competir pelos mesmos sítios de adsorção. Além do borato, outros ânions podem interagir com o silicato, Reifenberg \& Buckwold (1954) avaliaram o deslocamento de $\mathrm{H}_{4} \mathrm{SiO}_{4}$ para a solução pelo íon fosfato. $\mathrm{O}$ fosfato aumenta a concentração de sílica em solução pela competição direta pelos sítios de adsorção específica, já que a força de adsorção de fosfato é maior que a do $\mathrm{H}_{4} \mathrm{SiO}_{4}$. Obihara e Russel (1972) relataram que a presença de silicatos somente reduz a adsorção de fosfato em $\mathrm{pH}$ acima de 7 , quando a adsorção de silicato é aumentada e a de fosfato diminuída.

De acordo com Jones \& Handreck (1967) o silício é absorvido pelas plantas como ácido monosilícico, $\mathrm{H}_{4} \mathrm{SiO}_{4}$, e seu mecanismo de absorção parece ainda não

\footnotetext{
${ }^{3}$ COTTON, F. A.; WILKINSON, G. Advanced iniorganic chemistry. New York:John Wiley and Sons Inc., p. 185-6. 1962
} 
estar bem esclarecido, sendo provavelmente diferentes dependendo do tipo de planta. Os autores concluíram ser passiva a adsorsão do Si pelas plantas. Malavolta (1980), sem fazer referência a algum tipo especial de cultura, comenta que o processo de absorção, parece ser ativo, e é sensível a inibidores metabólicos e a temperatura. Como evidência do processo ativo, relata que na seiva bruta do arroz o teor de ácido monossilícico é centenas de vezes mais altu que na solução do solo.

Vorm (1980) trabalhando com $\mathrm{Si}$ em solução nutritiva, concluiu que a absorção passiva deste elemento pelas plantas, depende da espécie do vegetal e da concentração do ácido monosilíssico na superficie das plantas.

Segundo Wynn Parry \& Smithson (1964) o Si flui do xilema como ácido monosilíssico, e é depositado nas paredes celulares como silica amorfa ou como cristais, $\mathrm{e}$ que o Si pode estar associado com constituintes das paredes celulares ou ligados as pectinas.

$\mathrm{O}$ transporte e redistribuição do $\mathrm{Si}$ nas diferentes partes da plantas, depende da concentração e da transpiração. A solubilidade e a disponibilidade do Si normalmente aumenta o grau de finura da partícula do material silicatado. A adsorsão de Si diminui no pH 9,5. A principal forma na qual o Si é encontrado na planta é a sílica amorfa hidratada, $\mathrm{SiO}_{2} \mathrm{nH}_{2} \mathrm{O}$ e depois na forma de polímeros, formando complexos com polifenóis de grande estabilidade e baixa solubilidade. A maior parte do silício, depositase no apoplasto na forma sólida, onde se torna imóvel. Nas folhas de arroz, forma-se camada de sílica abaixo da cutícula, nas células epidérmicas das folhas, as quais segundo alguns autores (Malavolta, 1980; Marschner, 1986; Takahashi, 1996) teriam a função de limitar a perda de água e dificultar a penetração de hifas de fungos.

Segundo Souza \& Yasuda (1995) a sílica nas gramíneas reduz a transpiração e aumenta a resistência na penetração de fungos patogênicos e insetos. A barreira física das células epidérmicas silicatadas é que aumenta esta resistência, sendo que o Si diminui o dano às plantas causado pela concentração salina.

Depois de solidificado, abaixo da cutícula nas células epidérmicas, o $\mathrm{Si}$ torna-se imóvel na planta. A distribuição do Si depende muito da espécie, sendo uniforme 
nas plantas que acumulam pouco silício, sendo em outras em maior proporção nas raízes; e em plantas com muito Si, como o arroz por exemplo, cerca de $90 \%$ está na parte aérea (Malavolta, 1980).

Vários autores tem demonstrado que o Si pode acarretar um aumento na produção de cana-de-açúcar e de arroz em Histossois da Flórida, (Snyder et al., 1986 e Anderson et al., 1987).

O Si aumenta o poder de oxidação das raízes das gramíneas tornando baixa a toxidez de Fe e Mn, reduzindo temporariamente as doenças vindas pelos insetos, aumentando a resistência das plantas, a eficiência de água; e a utilização de P em solos cujos valores de pH são baixos (Plucnett, 1972; Elawad \& Green, 1979).

Tisdale \& Nelson (1985) afirmam que o Si contribui para a estrutura das paredes celulares, acumulando-se como polímeros hidratados ou sílica gel. $\mathrm{O} \mathrm{SiO}_{2}$ se transloca para a epiderme das paredes celulares, acumulando-se nos tecidos vasculares dando uma resistência aos tecidos vegetais, reduzindo com isso a perda de água e retardando a infecção por fungos. $\mathrm{O} \mathrm{SiO}_{2}$ pode acumular-se nos depósitos intracelulares até em formas de cristais. Segundo estes autores, uma das funções do Si no desenvolvimento da cana-de-açúcar é formar complexo de enzima-Si regulando a fotossintese e a atividade enzimática. Além disso, o Si pode diminuir a atividade da invertase, peroxidase, oxidase polifenólica e adenosinetrifosfatase em cana-de-açúcar. Estas supressões resultam numa grande produção de açúcar, essas atividades libertam uma alta energia otimizando o crescimento e a produção de cana-de-açúcar.

Segundo Weiss \& Herzog (1978) o ácido silicico dos vegetais reage com os orto-fenóis que são os precursores da biosintese da lignina para formar mono, di ou polímeros complexos de silício. De acordo com Werner \& Roth (1983) o Si retém água no solo, e é cumulativo nas gramíneas, hortaliças e nas pineaceaes que chegam a conter de 10 a $15 \%$ de $\mathrm{SiO}_{2}$ na matéria seca.

Os sintomas de deficiência de Si na cultura de arroz são necroses de folhas mais velhas, conforme Mitsui \& Takatoh (1963). Miyake \& Takahashi (1978) encontraram no tomateiro mal formação das folhas e frutos, atribuindo tais sintomas a 
deficiência de Si. Werner \& Roth (1983) demonstraram que na ausência de silicio em solução nutritiva, houve o aparecimento de deficiência em tomateiro, especialmente no estágio reprodutivo. O sintoma de deficiência caracterizou-se para formação anormal das folhas novas e uma falha de polinização com conseqüente não formação de frutos, em muitos casos, e com o passar do tempo o sintoma foi intensificado. As plantas deficientes, com teores de $200 \mu \mathrm{g} \mathrm{SiO}_{2} \mathrm{~g}^{-1}$ na matéria seca das raizes e das folhas tinham metade do peso daquelas que receberam silício, na solução nutritiva.

Werner \& Roth (1983) afirmaram que o sintoma típico de deficiência de silício em arroz é a necrose das folhas, que aparecem inicialmente nas partes mais baixas das plantas, o crescimento é menor e as folhas murcham e, segundo Malavolta (1980), a taxa de respiração é cerca de $30 \%$ mais alta nas plantas deficientes neste elemento do que em plantas normais.

O uso de silicatos em pepino e rosa, segundo Belanger et al. (1995) tem aumentado a produção destas culturas, diminuindo a infestação de fungos e doenças, atribuindo tal fato à absorção do silício. 


\section{MATERIAL E MÉTODOS}

Para atender a proposta deste trabalho, foram instalados dois experimentos em condições de campo sob plasticultura.

\subsection{Locais}

Áreas utilizadas e sua denominação:

Experimento 1 - instalado no dias 16 de abril de 1997 na Chácara Florença, localizada no Bairro de Nova Suíça no município de Piracicaba - SP e;

Experimento 2 - instalado no dia 27 de março de 1998 na Estância Santo Antônio, localizada na estrada Tabapuã-Novais, km 3,5, município de Tabapuã-SP. Os dois experimentos embora semelhantes, foram instalados em áreas e épocas diferentes e serão avaliados independentemente.

A variedade de tomate cultivada foi a Débora-Plus. O experimento 1 foi instalado em um solo Podzólico Vermelho-Amarelo abrupto, eutrófico, "A" moderado, textura arenosa/média. $O$ experimento 2 foi instalado também em um solo Podzólico Vermelho-Amarelo, eutrófico, $\mathrm{Tb}$, "A" moderado textura arenosa/média, cujas características químicas, obtidas a profundidade $0-20 \mathrm{~cm}$, estão apresentadas na tabela 4 .

Tabela 4. Análise química das amostras de solo coletadas antes da instalação dos experimentos.

\begin{tabular}{|c|c|c|c|c|c|c|c|c|c|c|}
\hline Experimento & $\begin{array}{c}\mathrm{pH} \\
\mathrm{CaCl}_{2}\end{array}$ & $\begin{array}{l}\text { M.O } \\
\text { g kg }^{-1}\end{array}$ & $\begin{array}{c}\mathrm{P} \\
\mathrm{mg} \mathrm{dm^{-3 }}\end{array}$ & $\mathrm{K}$ & $\mathrm{Ca}$ & $\begin{array}{r}\mathrm{Mg} \\
\mathrm{mmol}\end{array}$ & $\begin{array}{l}\mathrm{H}+\mathrm{Al} \\
\mathrm{dm}^{-3}-\cdots\end{array}$ & SB & $\mathrm{T}$ & $\begin{array}{l}\mathrm{V} \\
\% \\
\end{array}$ \\
\hline 1 & 5,2 & 15 & 111 & 1,7 & 29 & 14 & 20 & 45 & 65 & 69 \\
\hline 2 & 5,0 & 17 & 90 & 2,8 & 28 & 9 & 34 & 40 & 74 & 54 \\
\hline
\end{tabular}




\subsection{Material utilizado}

Os produtos utilizados neste trabalho, com exceção do termofosfato, são residuos minerais que passaram por processos industriais e são depositados em grande quantidade em áreas consideradas de sacrificio. Suas características químicas, são apresentadas nas Tabelas 5 e 6.

Tabela 5. Resultados da análise química determinada pelo espectrofotômetro de plasma em extração com ácido cloridrico ${ }^{(1)}$.

\begin{tabular}{|c|c|c|c|c|c|c|c|c|c|c|}
\hline Elementos & $\bar{P}$ & $\mathrm{Ca}$ & $\mathrm{Mg}$ & $\mathrm{Al}$ & $\mathrm{Fe}$ & $\mathrm{Ti}$ & $\mathrm{Cu}$ & $\mathrm{Zn}$ & $\mathrm{Mn}$ & $\overline{\mathrm{Cr}}$ \\
\hline Produtos & $\cdots$ & 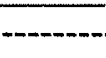 & $--\mathrm{g} \mathrm{kg}$ & & $\cdots$ & $\ldots$ & $\cdots$ & $\mathrm{mg} \mathrm{kg}$ & $\cdots$ & $\ldots$ \\
\hline Xisto & 1,1 & 14,5 & 9,6 & 24,8 & 46,1 & 457 & 60 & 229 & 434 & 55 \\
\hline Escória (Mannesman) & 1,3 & 141,3 & 53,7 & 32,3 & 94,8 & 883 & 398 & 224 & 12260 & 700 \\
\hline Escória (Dedini) & 3,2 & 193,3 & 61,1 & 29,1 & 302,7 & 2212 & 203 & 724 & 25640 & 4396 \\
\hline Termofosfato & 79,5 & 204,1 & 105,4 & 29,7 & 69,9 & 3219 & 435 & 4879 & 2213 & 910 \\
\hline \multirow[t]{2}{*}{ Elementos } & Mo & $\overline{\mathrm{Co}}$ & $\overline{\mathrm{Ni}}$ & $\mathrm{Pb}$ & $\overline{\mathrm{Ba}}$ & $\overline{\mathrm{Sr}}$ & $\mathrm{Cd}$ & $\bar{B}$ & $\overline{\mathrm{V}}$ & $\overline{\text { M.O. }^{(2)}}$ \\
\hline & & & & -- & ng kg & & & $\cdots$ & $\cdots$ & $\mathrm{g} \mathrm{kg}^{-1}$ \\
\hline Xisto & 79 & 25 & 57 & 109 & 204 & 101 & 4 & 51 & 152 & 150 \\
\hline Escória (Mannesman) & 182 & 61 & 398 & 326 & 234 & 579 & 10 & 67 & 334 & - \\
\hline Escória (Dedini) & 340 & 61 & 175 & 354 & 919 & 684 & 24 & 254 & 904 & - \\
\hline Termofosfato & 237 & 82 & 418 & 235 & 30440 & 5400 & 11 & 1190 & 369 & - \\
\hline
\end{tabular}

1) Matéria orgânica determinada por ditionito

2) M.O. = Matéria orgânica

Tabela 6. Resultados da análise química do $\mathrm{S}$ total, $\mathrm{SiO}_{2}$ extraído por ácido fluorídrico e de $\mathrm{SiO}_{2}, \mathrm{AlO}_{3}, \mathrm{Fe}_{2} \mathrm{O}_{3}, \mathrm{TiO}_{2}$ e $\mathrm{MnO}$ determinados através de extração com ácido sulfúrico.

$$
\text { Ac. }
$$$$
\text { Ac. sulfúrico }
$$

$S$ total fluoridrico

\begin{tabular}{|c|c|c|c|c|c|c|c|}
\hline \multicolumn{2}{|l|}{ Elementos } & $\mathrm{SiO}_{2}$ & $\mathrm{SiO}_{2}$ & $\overline{\mathrm{Al}_{2} \mathrm{O}_{3}}$ & $\mathrm{Fe}_{2} \mathrm{O}_{3}$ & $\mathrm{TiO}_{2}$ & $\mathrm{MnO}$ \\
\hline Produtos & $-\ldots$ & - & $\ldots$ & $\mathrm{kg}^{-1}-\cdots$ & & & \\
\hline Xisto & 31,8 & 530,0 & 133,8 & 54,0 & 61,1 & 13,1 & 0,5 \\
\hline Escória (Mannesman) & 1,0 & 350,0 & 50,0 & 15,3 & 142,6 & 11,4 & 16,4 \\
\hline Escória (Dedini) & 1,9 & 273,0 & 65,6 & 20,6 & 387,7 & 27,6 & 35,4 \\
\hline Termofosfato & 0,7 & 185,0 & 127,0 & 7,6 & 74,2 & 17,1 & 2,3 \\
\hline
\end{tabular}




\subsection{Delineamento experimental e análise dos resultados}

O delineamento adotado foi o de blocos completos ao acaso com oito tratamentos e quatro repetições, totalizando trinta e duas parcelas.

A análise dos resultados foi realizada com a obtenção do teste $F$ para tratamentos, e a comparação entre todos com o teste Tukey. Em alguns casos, achou-se conveniente, realizar a regressão polinomial para os tratamentos de xisto com o objetivo de analisar o efeito isolado das doses de xisto em relação a testemunha.

\subsection{Instalação e condução dos experimentos.}

Os experimentos foram instalados sob plasticultura, em estufas de estrutura metálica na forma de arco com $7 \mathrm{~m}$ de largura por 60 metros de comprimento, a altura do vão central tinha $4,5 \mathrm{~m}$. Eram cobertas com plástico transparente de $150 \mu \mathrm{m}$ e com as laterais fechadas com tela de sombrite preto $30 \%$. A irrigação utilizada foi do tipo gotejamento com injetor de fertilizante tipo venturi para se proceder a fertirrigação com $\mathrm{N}$ e K.

Os tratamentos constaram de uma testemunha (só adubação NPK), quatro doses de xisto e três tipos de escórias (a escória é uma das principais matériaprima para a obtenção do termofosfato, por isso o consideraremos com tal), conforme apresentados na Tabela 7 .

Como ainda não há critérios para doses de xisto a serem utilizadas, optou-se por doses crescentes até $12 \mathrm{Mg} \mathrm{ha}^{-1}$. Esta dose foi determinada visando a viabilidade econômica do produto, bem como, evitar doses elevadas que pudessem vir a causar danos ao ambiente, pois não se sabe ainda quais os efeitos deste produto no solo e para a cultura.

Após o preparo do solo a área foi demarcada e estaqueada para a aplicação dos resíduos (tratamentos). 
Tabela 7. Tratamentos utilizados nos experimentos.

\begin{tabular}{cccc}
\hline $\begin{array}{c}\text { TRATA- } \\
\text { MENTOS }\end{array}$ & IDENTIFICAÇÃO & PRODUTOS & $\begin{array}{c}\text { DOSES } \\
\left(\mathrm{Mg} \mathrm{ha}^{-1}\right)\end{array}$ \\
\hline 1 & Testemunha & TESTEMUNHA & - \\
2 & xisto $\left(3 \mathrm{Mg} \mathrm{ha}^{-1}\right)$ & XISTO RETORTADO & 3 \\
3 & xisto $\left(6 \mathrm{Mg} \mathrm{ha}^{-1}\right)$ & XISTO RETORTADO & 6 \\
4 & xisto $\left(9 \mathrm{Mg} \mathrm{ha}^{-1}\right)$ & XISTO RETORTADO & 9 \\
5 & xisto $\left(12 \mathrm{Mg} \mathrm{ha}^{-1}\right)$ & XISTO RETORTADO & 12 \\
6 & Escória (M) & ESCÓRIA DA MANNESMAM & 6 \\
7 & Escória (D) & ESCÓRIA DA DEDINI & 6 \\
8 & Termofosfato & TERMOFOSFATO (Pó) & 2,5 \\
\hline
\end{tabular}

A obtenção das mudas de tomate foi feita através do plantio em bandeja de isopor com 128 células, usando-se como substrato o Plantimax da Eucatex. Vinte e cinco dias após a germinação das plantas foi realizado o transplante do tomate em linhas duplas no espaçamento de $0,5 \times 0,5 \times 1,25(0,5$ metro entre plantas, 0,5 metro na linha dupla e 1,25 metros entre as linhas duplas de plantio). As parcelas constaram de uma linha dupla de 6 metros de comprimento, perfazendo uma área de $10,5 \mathrm{~m}^{2}$ por parcela. A adubação básica de plantio foi feita em área total, antes do plantio e após a aplicação dos resíduos, incorporados com enxada rotativa, sendo aplicado $450 \mathrm{~kg} \mathrm{ha}^{-1}$ de $\mathrm{P}_{2} \mathrm{O}_{5}$ na forma de superfosfato triplo com exceção do tratamento 8 no qual adotou-se o termofosfato. A adubação NK, foi aplicada via fertirrigação nas doses de $350 \mathrm{~kg} \mathrm{ha}^{-1}$ de $\mathrm{N}$ e $500 \mathrm{~kg} \mathrm{ha}^{-1}$ de $\mathrm{K}_{2} \mathrm{O}$, seguindo as recomendações de Trani et al. (1996) para a cultura do tomateiro.

Além da adubação NPK, foram feitas, semanalmente após o início da frutificação, adubações foliares com $\mathrm{Ca}\left(\mathrm{CaCl}_{2}\right.$ a $\left.0,15 \%\right), \mathrm{Mg}$ (quelatizado orgânico com $85 \mathrm{~g} \mathrm{~kg}^{-1}$ de $\mathrm{Mg}$ a $0,05 \%$ ), B (Ácido bórico a 0,07\%), e Mn (quelatizado orgânico com $140 \mathrm{~g} \mathrm{~kg}^{-1}$ de $\mathrm{Mn}$ a $0,05 \%$ ). No experimento 1 as aplicações de $\mathrm{Mg}$ e $\mathrm{Mn}$ ocorreram, após o início da colheita quando verificou-se sintomas de deficiência destes elementos, já no experimento 2 estas aplicações ocorreram desde o início das pulverizações. 
Junto com as pulverizações semanais, foi também realizada o controle de pragas e doenças. Para o controle de pragas usou-se alternadamente até o início da frutificação Imidacloprid (Confidor $700 \mathrm{GrDA}$ ) associado com deltamethine (Decis 25 CE) e Esfenvalerate (Sumidam 25 CE) associado com Fenitrothion (Sumithion $500 \mathrm{CE}$ ) com o objetivo de controlar principalemnte mosca branca, traça e liromisa; após o início da frutificação, além destas pragas deve se controlar também as brocas do fruto, passando então a ser usado alternadamente Carbamoitio (Cartap BR 500 PS) associado com deltamethine (Decis $25 \mathrm{CE}$ ) e Esfenvalerate (Sumidam $25 \mathrm{CE}$ ) ou Triflumuron (Alsistim 250 PM) associado com Trichlorfon (Dipterex 500 SC). Para o controle de doenças foi aplicado alternadamente Benomyl (Benlate 500 PM) associado com Clhorotalonil $\left(250 \mathrm{~g} \mathrm{~kg}^{-1}\right)+$ oxicloreto de cobre $\left(300 \mathrm{~g} \mathrm{~kg}^{-1}\right)$ (Dacobre PM) e Carbendazin (Derosal $500 \mathrm{SC}$ ) associado com Metalaxyl $\left(80 \mathrm{~g} \mathrm{~kg}^{-1}\right)+$ Mancozeb $\left(640 \mathrm{~g} \mathrm{~kg}^{-1}\right)$ (Ridomil mancozeb PM), buscando controlar as principais doenças como fuzariose, talo oco, septoriose, requeima e pinta preta.

\subsection{Avaliações.}

\subsubsection{Análises de plantas}

No periodo de aparecimento dos primeiros frutos maduros foram realizadas amostragens de folhas, coletando-se as mesmas logo abaixo e opostas ao segundo cacho floral (Malavolta et al., 1997). Para a determinação de nutrientes foram separados folíolos e pecíolos em amostras distintas, cujos teores dos macronutrientes $(\mathrm{N}$, $\mathrm{P}, \mathrm{K}, \mathrm{Ca}, \mathrm{Mg}$ e $\mathrm{S}$ ) e de micronutrientes ( $\mathrm{B}, \mathrm{Cu}, \mathrm{Fe}, \mathrm{Mn}$ e $\mathrm{Zn}$ ) foram determinadas usando metodologia de Malavolta et al. (1997).

O silício foi determinado por dois métodos: 1) Método azul - conforme Furlani et al. (1978) e/ou Bataglia et al. (1983) que consiste basicamente na extração do Si no material vegetal por fusão da amostra em cadinho de níquel e solubilização com hidróxido de sódio; a quantificação foi através da formação do complexo BETA- 
molibdosilicato reduzido pelo ácido ascórbico ou "azul-de-molibdênio" e leitura em colorímetro a $810 \mathrm{~nm}$ (Kilmer, 1965). 2) Método amarelo - conforme Malavolta et al. (1997), consiste na extração do $\mathrm{Si}$ com digestão do material vegetal com $\mathrm{H}_{2} \mathrm{O}_{2} 50 \%+$ $\mathrm{NaOH}$ em autoclave; e a quantificação através da formação do complexo BETAmolibdosilicato de coloração amarela estabilizada pelo ácido oxálico e leitura em colorímetro a $410 \mathrm{~nm}$.

Também foram determinados os metais pesados nos tecidos vegetais: Mo, $\mathrm{Ni}, \mathrm{Cd}, \mathrm{Cr}, \mathrm{Pb}, \mathrm{Co}, \mathrm{Ti}, \mathrm{Ba}, \mathrm{V}, \mathrm{Cu}, \mathrm{Fe}, \mathrm{Mn}$ e $\mathrm{Zn}$. A quantificação foi feita em espectrometro de emissão atômica com plasma de argônio, em extrato obtido com digestão nítro-perclórica de $1 \mathrm{~g}$ do material vegetal e diluindo-se o extrato em $25 \mathrm{ml}$ (Malavolta et al., 1997).

\subsubsection{Análises químicas dos solos}

Logo após a colheita, procedeu-se uma amostragem de solo nas profundidades $0-10$ e $10-20 \mathrm{~cm}$, retirando-se amostras nas linhas de plantio com amostrador de solo do tipo "sonda". As amostras foram analisadas quimicamente conforme Raij \& Quaggio (1983), para os seguintes parâmetros: $\mathrm{pH}_{\mathrm{CaCl} 2}, \mathrm{P}, \mathrm{K}^{+}, \mathrm{Ca}^{2+}$, $\mathrm{Mg}^{2+}, \mathrm{H}+\mathrm{Al} ;{\mathrm{S}-\mathrm{SO}_{4}}^{-2}$ conforme Vitti (1989); e os micronutrientes: B pelo método da água quente (Berger \& Truog, 1939), Cu, Fe, Mn e Zn, pelo método DTPA (Lindsay \& Morvell, 1978). A partir da obtenção desses atributos químicos do solo, calcularam-se a soma de bases (SB), a capacidade de troca catiônica $(\mathrm{T})$ e os valores de saturação por bases $(\mathrm{V} \%)$.

A análise de silício efetuada extraindo-se o elemento com oxalato de amônio $0,2 \mathrm{M}$ a pH 3,0, conforme Smith (1984). A quantificação foi feita através da formação do complexo BETA-molibdosilicato reduzido pelo ácido ascórbico ou "azulde-molibdênio" e leitura em colorímetro a 810nm (Kilmer, 1965).

Realizou-se também as análises dos metais pesados no solo: $\mathrm{Mo}, \mathrm{Ni}, \mathrm{Cd}$, $\mathrm{Cr}, \mathrm{Pb}, \mathrm{Co}, \mathrm{Ti}, \mathrm{Ba}, \mathrm{V}, \mathrm{Cu}, \mathrm{Fe}, \mathrm{Mn}$ e $\mathrm{Zn}$, para verificar se as doses utilizadas poderiam 
causar alterações nas quantidades destes metais. A análise foi realizada através da espectrometria de emissão atómica com plasma de argônio e o extrator Mehlich III (Mehlich, 1984).

\subsubsection{Análises microbiológicas dos solos}

As análises microbiológicas realizadas: a) determinação do número de fungos e bactérias em amostras de solo das parcelas ao final da colheita fazendo-se sua contagem pelo método de plaqueamento por gotas (Jahnel, 1997); b) determinação da degradabilidade do xisto no solo através da respirometria, ou liberação do $\mathrm{CO}_{2}, \operatorname{logo}$ após aplicação dos tratamentos; c) avaliação das condições microbiológicas do solo em função dos tratamentos também através da respirometria. $\mathrm{O} \mathrm{CO}_{2}$ liberado constitui-se uma das vias mais importante de retorno de $\mathrm{C}$ para a atmosfera e é uma das formas de se medir a atividade microbiana no solo, usando-se o método da fixação do $\mathrm{CO}_{2}$ liberado pelo $\mathrm{NaOH}$, e posterior titulação com ácido sulfúrico (Stozky, 1965).

Devido a baixa atividade biológica obtida no experimento 1, optou-se em fazer além das avaliações com o solo normal, avaliações do solo ativado com açúcar, no experimento 2. O objetivo foi aumentar a atividade dos microorganismos, colocando-se uma fonte de energia prontamente disponível, e assim aumentando a respiração. Desta forma, se em algum tratamento o produto aplicado estiver causando algum dano aos microorganismos, impedindo-o de alguma forma seu desenvolvimento, facilmente será observado quando comparado aos demais tratamentos.

\subsubsection{Análise da produção}

As colheitas de tomate foram realizadas semanalmente ou até duas vezes por semanas, procurando avaliar a produção de frutos através de pesagens, contagens e posteriormente determinação do peso médio por fruto. 


\section{RESUlTADOS E DISCUSSÃo}

\subsection{Avaliações químicas dos solos}

Os resultados analiticos das amostras de solo estão apresentados nas tabelas 8 e 9 para profundidade $0-10 \mathrm{~cm}$ dos experimentos 1 e 2 respectivamente, e nas tabelas 10 e 11 para profundidade $10-20 \mathrm{~cm}$. Através destes resultados pode-se observar o efeito dos tratamentos em atributos químicos do solo.

Avaliando-se os resultados observa-se que os tratamentos com xisto não influenciaram no valor $\mathrm{pH}$ do solo, mesmo nas doses mais elevadas, nas profundidades 0-10 e 10-20cm; enquanto as escórias e o termofosfato causaram uma elevação nesse valor, apresentando diferenças significativas no experimento 2 na profundidade $10-20 \mathrm{~cm}$, quando comparado com a testemunha. Verifica-se que as escórias proporcionaram um aumento nos teores de $\mathrm{Ca}$ e $\mathrm{Mg}$ e redução no $\mathrm{H}+\mathrm{Al}$, o que reflete nos valores de soma de bases e na saturação por bases. O aumento nos teores de Ca causado pelas escórias diferiram significativamente da testemunha na profundidade de $0-10 \mathrm{~cm}$, em ambos experimentos, e apenas a escória da Dedini diferiu significativamente na profundidade 10-20cm. Resultados semelhantes foram observados por Fox et al. (1967); Smith \& Sanches (1980); Firme (1986) e Rodriguez et al. (1994), que constataram aumento do valor $\mathrm{pH}$, e dos teores de $\mathrm{Ca}$ e $\mathrm{Mg}$ trocáveis com o incremento de doses de escória.

Embora não significativo no experimento 1 , os teores de fósforo apresentaram elevação no solo em função dos tratamentos, esta elevação foi significativa na dose $12 \mathrm{Mg} \mathrm{ha}^{-1}$ de xisto, e para a escória da Dedini na profundidade $0-10 \mathrm{~cm}$, no experimento 2. Esta variação pode ter ocorrido devido a ação dos silicatos na reação do solo e na competição da sílica pelos mesmos sítios de adsorção do fósforo (Reifenberg \& 


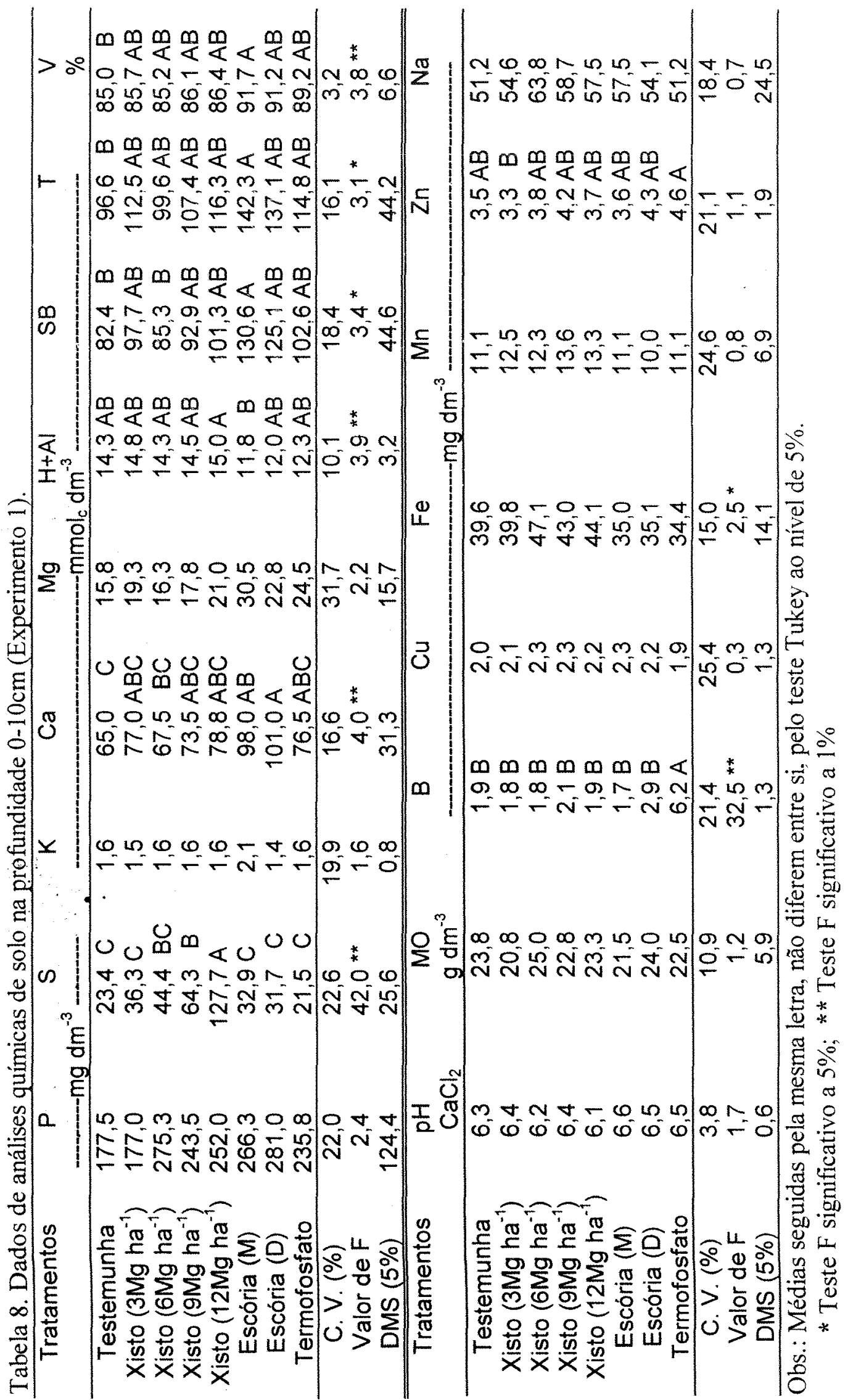




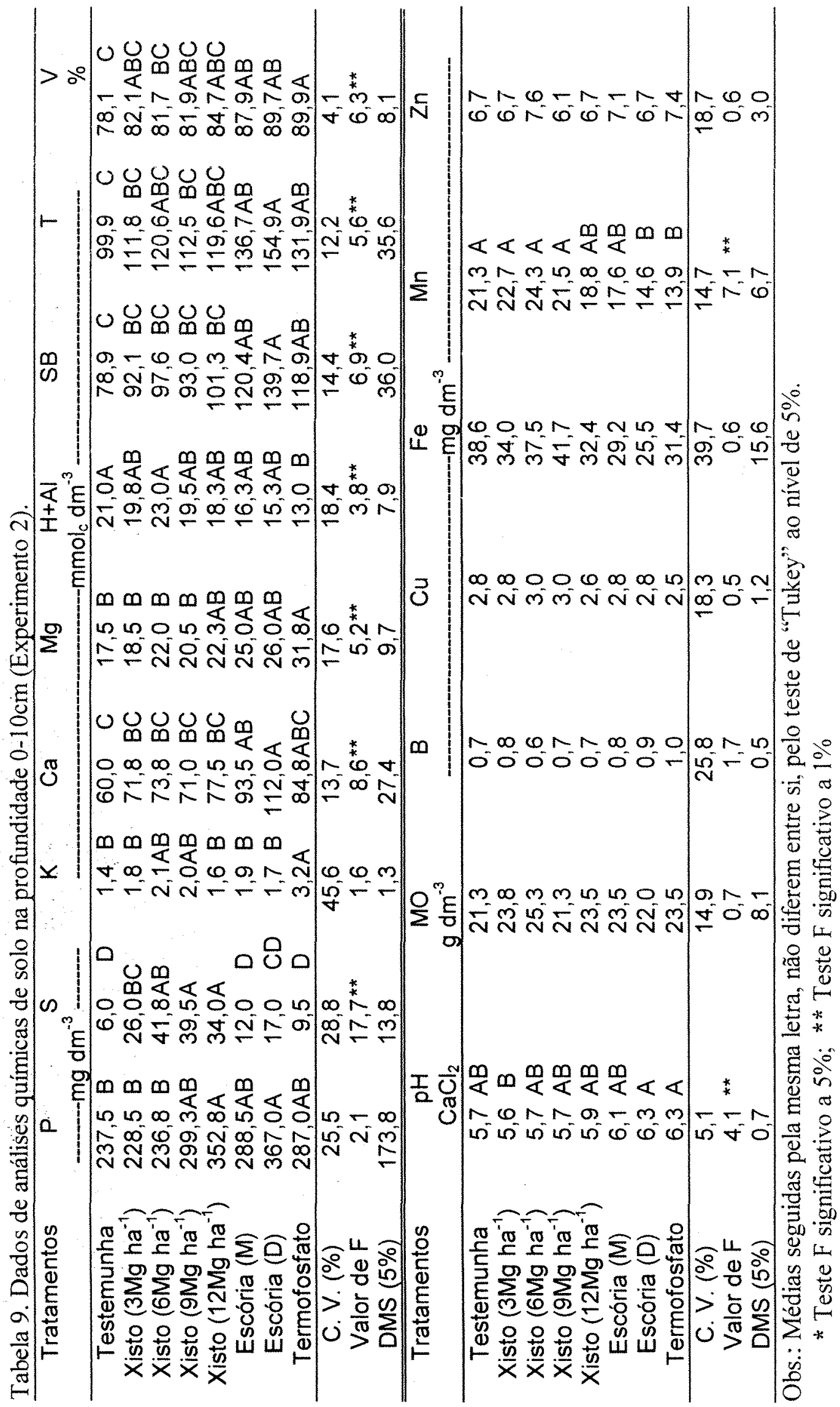




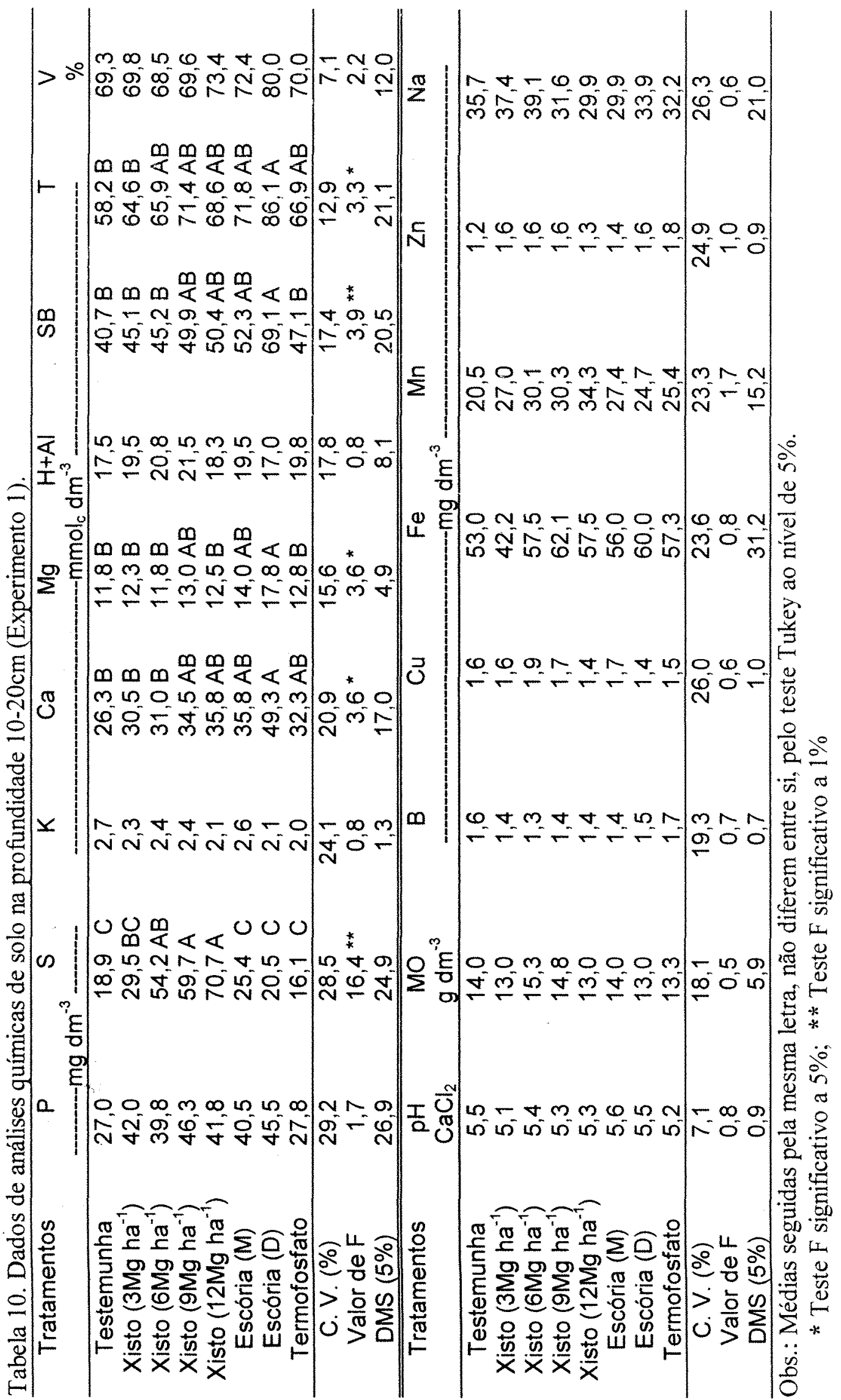




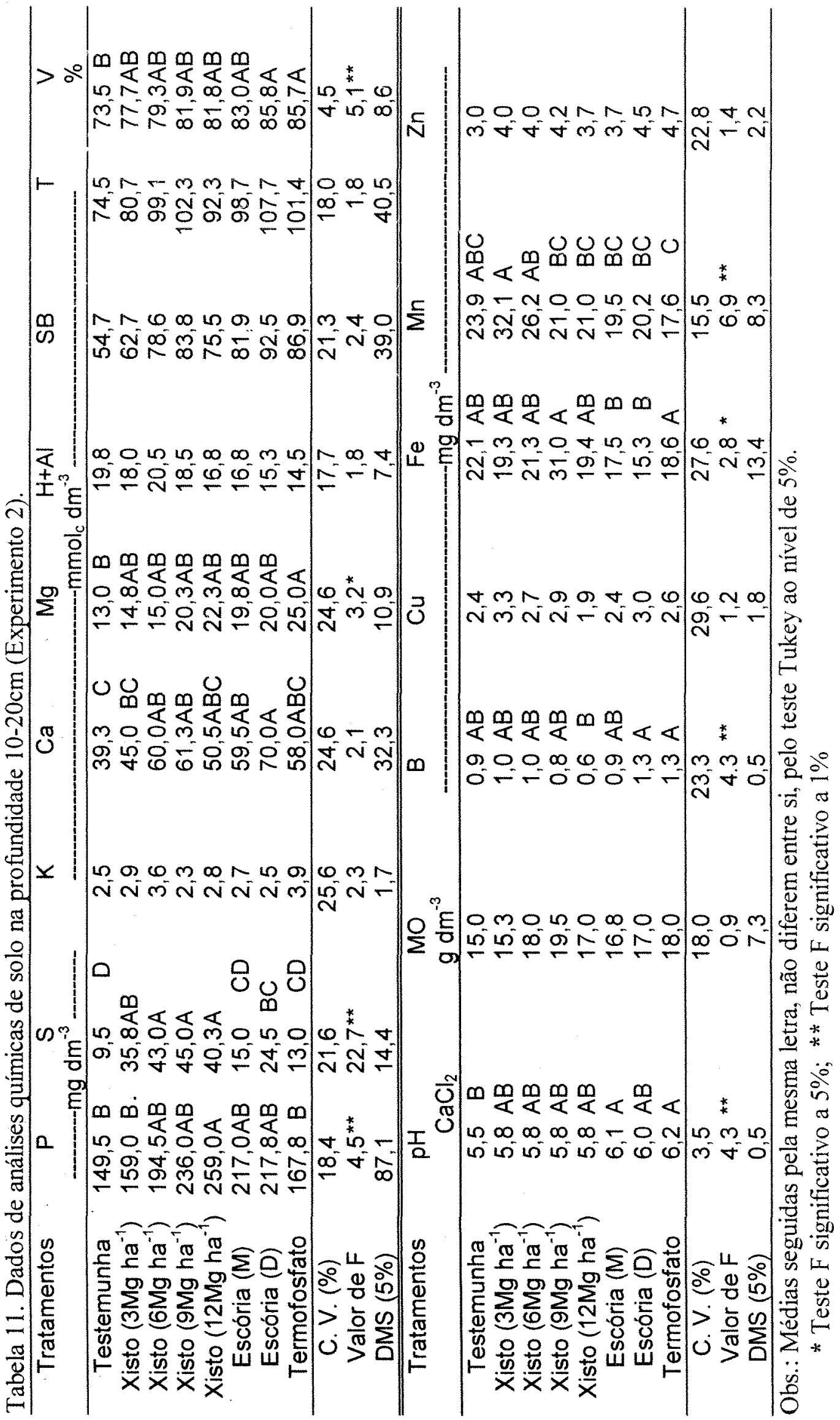


Buckwold, 1954). Outros autores, como Taylor (1961); Obihara \& Russel (1972) e Smith \& Sanches (1980) comentam que a disponibilidade de fósforo pode ser aumentada pela adição de silicatos e resultados semelhantes obtiveram com a adição de escória de siderurgia.

Os tratamentos com xisto promoveram aumentos significativos nos teores de enxofre no solo. A elevação na concentração de enxofre no solo em função das doses de xisto, é justificada pela sua concentração e disponibilidade elevada no resíduo, na forma de pirita (Grossi Sad et al., 1984). Não verificou-se alterações significativas na matéria orgânica do solo, embora o xisto contenha em sua composição química quantidades expressivas da mesma.

Quanto aos micronutrientes, verificou-se que os tratamentos com escórias promoveram redução nos teores de ferro e principalmente manganês, com diferenças significativas no experimento 2 para o $\mathrm{Mn}$, e o Fe apenas na camada $10-20 \mathrm{~cm}$. Isto, pode ter ocorrido devido a elevação no valor $\mathrm{pH}$ provocada por estes produtos. Diminuição do Mn em função da aplicação de escórias, também foram observados por Fox et al. (1967) e Elawad \& Green (1979). Os tratamentos não apresentaram diferenças significativas com relação aos demais micronutrientes, com exceção do $\mathrm{B}$ e $\mathrm{Zn}$ nos tratamentos com termofosfato, onde apresentaram teores mais elevados, chegando a significancia no experimento 2 na camada $10-20 \mathrm{~cm}$. Isto se deve a maior concentração destes elementos neste fertilizante.

\subsubsection{Avaliação do silício nos solos}

Os resultados analíticos de silício obtidos em amostras de solo estão apresentados na tabela 12 .

O método usado tem por objetivo extrair as formas mais solúveis de Si no solo. Isto explica a baixa concentração de silício nos resultados, pois conforme apresentado por Hopps et al. (1977), a sílica dissolvida em solução na forma de $\mathrm{H}_{4} \mathrm{SiO}_{4}$, ocorre em concentrações próximas ao equilíbrio, podendo variar de 1 a $200 \mathrm{mg} \mathrm{dm}^{-3}$ no 
Tabela 12. Teor de silício no solo dos experimentos extraído com oxalato de amônio.

\begin{tabular}{|c|c|c|c|c|}
\hline \multirow[b]{2}{*}{ Tratamentos } & \multicolumn{2}{|c|}{ Experimento 1} & \multicolumn{2}{|c|}{ Experimento 2} \\
\hline & $0-10 \mathrm{~cm}$ & $10-20 \mathrm{~cm}$ & $0-10 \mathrm{~cm}$ & $10-20 \mathrm{~cm}$ \\
\hline & & $n$ & & \\
\hline Testemunha & $53,35 \quad B$ & 36,39 & $83,68 \quad B$ & 70,51 \\
\hline Xisto $\left(3 \mathrm{Mg} \mathrm{ha}^{-1}\right)$ & 57,74 B & 37,19 & $97,05 \quad \mathrm{~B}$ & $87,07 \quad \mathrm{BC}$ \\
\hline Xisto $\left(6 \mathrm{Mg} \mathrm{ha}^{-1}\right)$ & $62,53 \quad \mathrm{~B}$ & 39,19 & $100,44 B$ & $90,06 \quad \mathrm{BC}$ \\
\hline Xisto (9Mg ha $\left.{ }^{-1}\right)$ & $64,53 \mathrm{AB}$ & 42,38 & $100,64 \mathrm{~B}$ & $97.45 \mathrm{ABC}$ \\
\hline Xisto (12Mg ha $\left.{ }^{-1}\right)$ & $69,11 \mathrm{AB}$ & 47,96 & $108,62 \quad \mathrm{~B}$ & $106,42 \mathrm{ABC}$ \\
\hline Escória (M) & $114,80 \mathrm{~A}$ & 36,79 & $207,38 \mathrm{~A}$ & $133,96 \mathrm{~A}$ \\
\hline Escória (D) & $96,45 \mathrm{AB}$ & 56,74 & $114,60 \mathrm{~B}$ & $90,26 \mathrm{BC}$ \\
\hline Termofosfato & $71,91 \mathrm{AB}$ & 44,17 & $170,07 \mathrm{~A}$ & $113,41 \mathrm{AB}$ \\
\hline C. V. $(\%)$ & 28,95 & 22,44 & 13,19 & 16,22 \\
\hline Valor de $\mathrm{F}$ & 3,89 ** & 2,15 & $27,97^{* *}$ & $5,80^{* *}$ \\
\hline DMS $(5 \%)$ & 50,6 & 22,7 & 38,4 & 37,9 \\
\hline
\end{tabular}

Obs.: Médias seguidas pela mesma letra, não diferem entre si, pelo teste Tukey ao nível de $5 \%$.

* Teste F significativo a 5\%; ** Teste F significativo a $1 \%$.

solo. Devido a este equilíbrio, a adição de compostos solúveis de silício não eleva muito a concentração de $\mathrm{H}_{4} \mathrm{SiO}_{4}$ em solução, já que esta passa rapidamente para a fase sólida (Elgawhary \& Lindsay, 1972). Os minerais silicatados estão em equilibrio com o $\mathrm{H}_{4} \mathrm{SiO}_{4}$ em solução e só se solubilizarão quando a concentração na solução do solo se reduzir (Baker \& Scrivner, 1985). Desta forma a concentração de sílica em solução, será tanto maior quanto for a quantidade de sílica que pode ser solubilizada da fase sólida. Assim, observa-se através dos resultados que os tratamentos aumentaram os teores de silício solúvel no solo extraídos com oxalato de amônio. A escória da Mannesman foi a que proporcionou maior teor de silício no solo, com exceção na profundidade $10-20 \mathrm{~cm}$, no experimento 1, com diferença significativa na comparação com a testemunha. Verifica-se que o termofosfato, também apresentou diferença significativa em relação a testemunha, no experimento 2 .

O xisto retortado apresenta elevação dos teores de silicio com o aumento nas doses, como observado na Figura 1. Embora apresente valores sempre maiores, não são significativos, quando comparados a testemunha. 


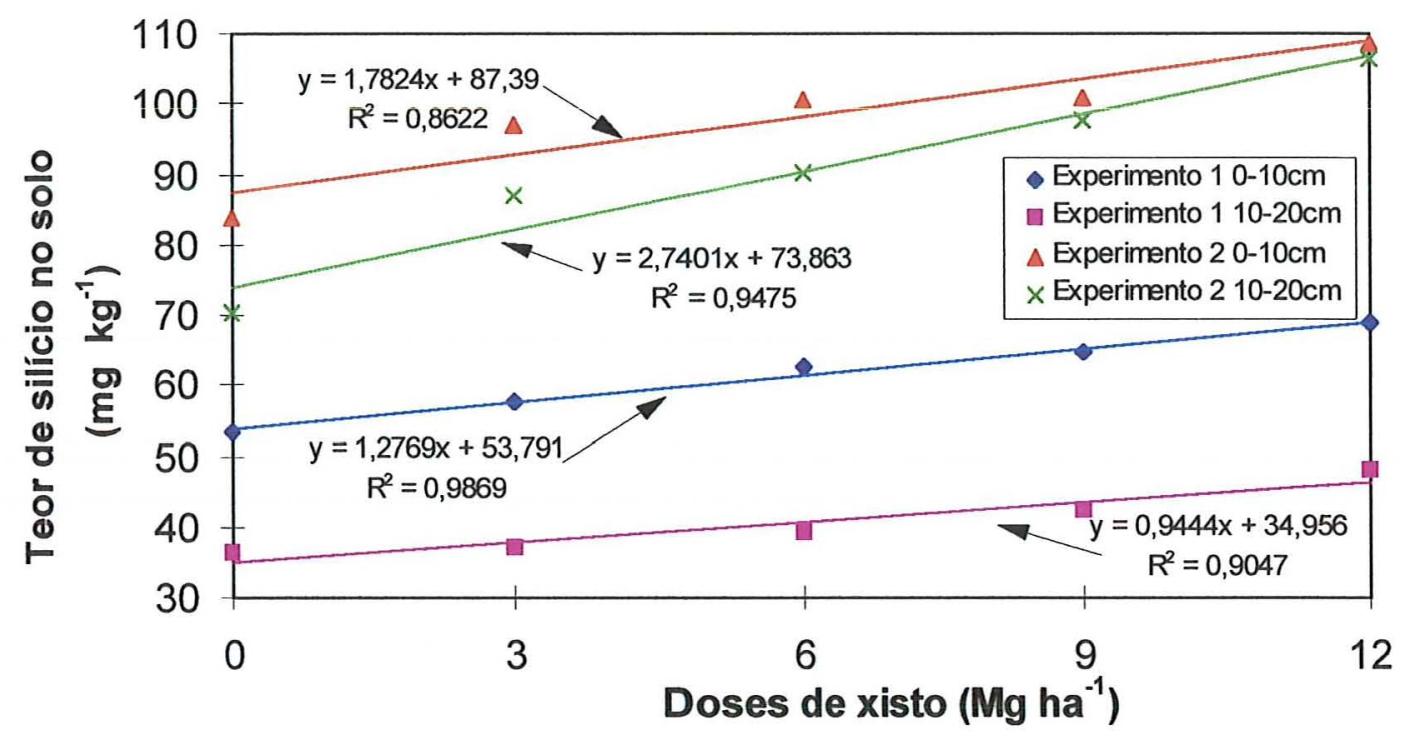

Figura 1. Regressão linear do silício no solo em função de doses de xisto.

\subsubsection{Avaliação de metais pesados nos solos}

Nas Tabelas 13 e 14 são apresentados os resultados das análises de metais pesados nos experimentos 1 e 2 no solo na profundidade de 0 a $20 \mathrm{~cm}$, respectivamente.

Verifica-se, através dos resultados que o termofosfato foi o tratamento que apresentou as maiores alterações dos teores de metais no solo, aumentando significativamente o $\mathrm{Ti}$ e o $\mathrm{Ba}$ no experimento 1, e Ni, Ti, V e Zn no experimento 2. Outro tratamento que apresentou diferenças significativas foi a escória da Dedini, onde no experimento 2 aumentou significativamente os teores de $\mathrm{Cr}$, Ti e V, estes aumentos ocorreram provavelmente devido as concentrações mais elevadas destes elementos na composição destes produtos. $\mathrm{O} \mathrm{Cr}$ que manifestava-se com teor elevado na escória da Dedini, não apresentou um aumento elevado no solo, sendo observado diferenças apenas no experimento 2, segundo Bartlett \& James (1976), isto ocorre devido a precipitação deste elemento quando o valor $\mathrm{pH}$ do solo ultrapassa 5,5.

Apesar de aumentos significativos nos teores de metais no solo, principalmente por parte da escória da Dedini e do termofosfato, verifica-se que os teores dos mesmos estão abaixo dos limites estabelecidos pelo Environmental Protection 


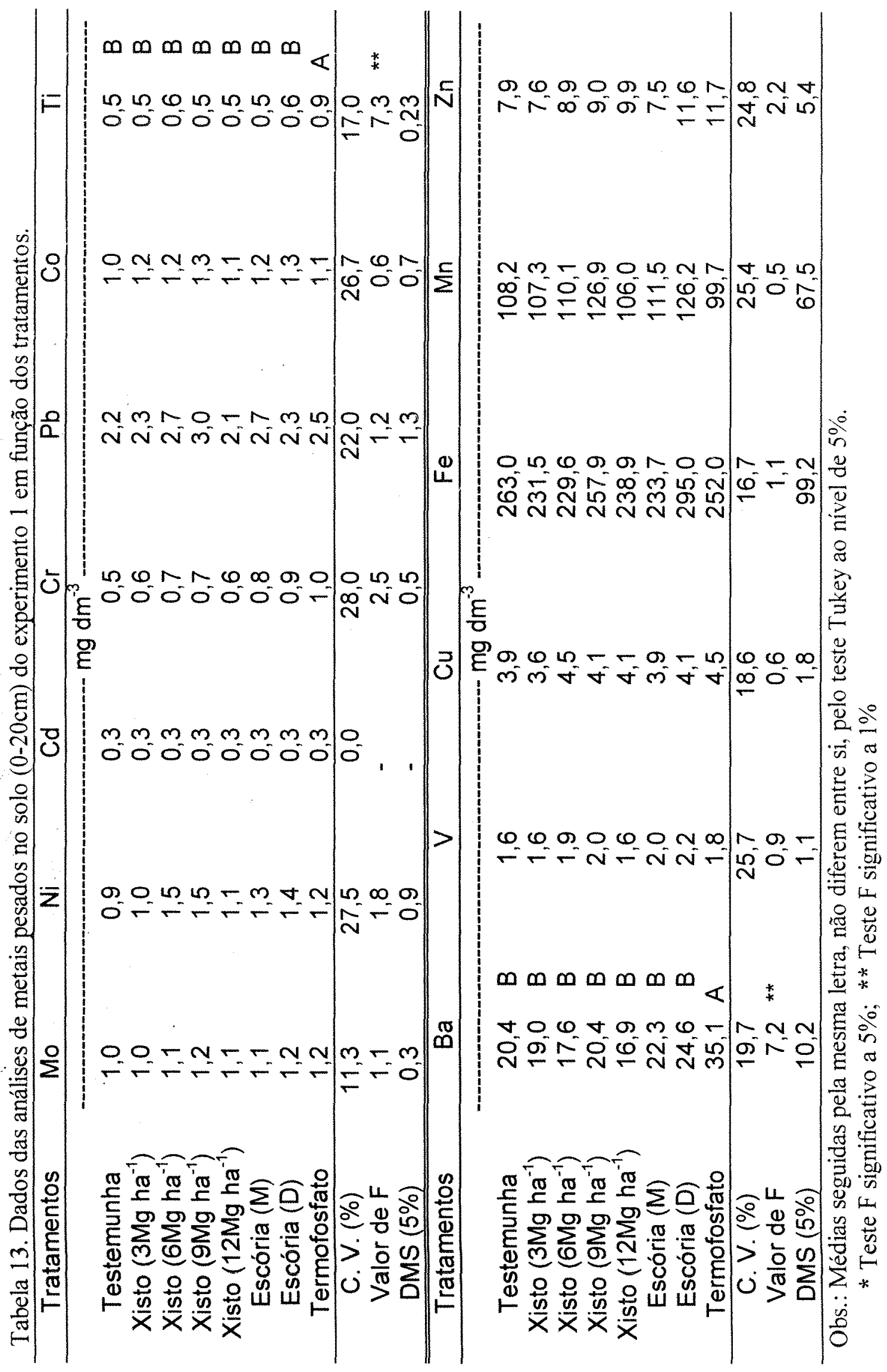




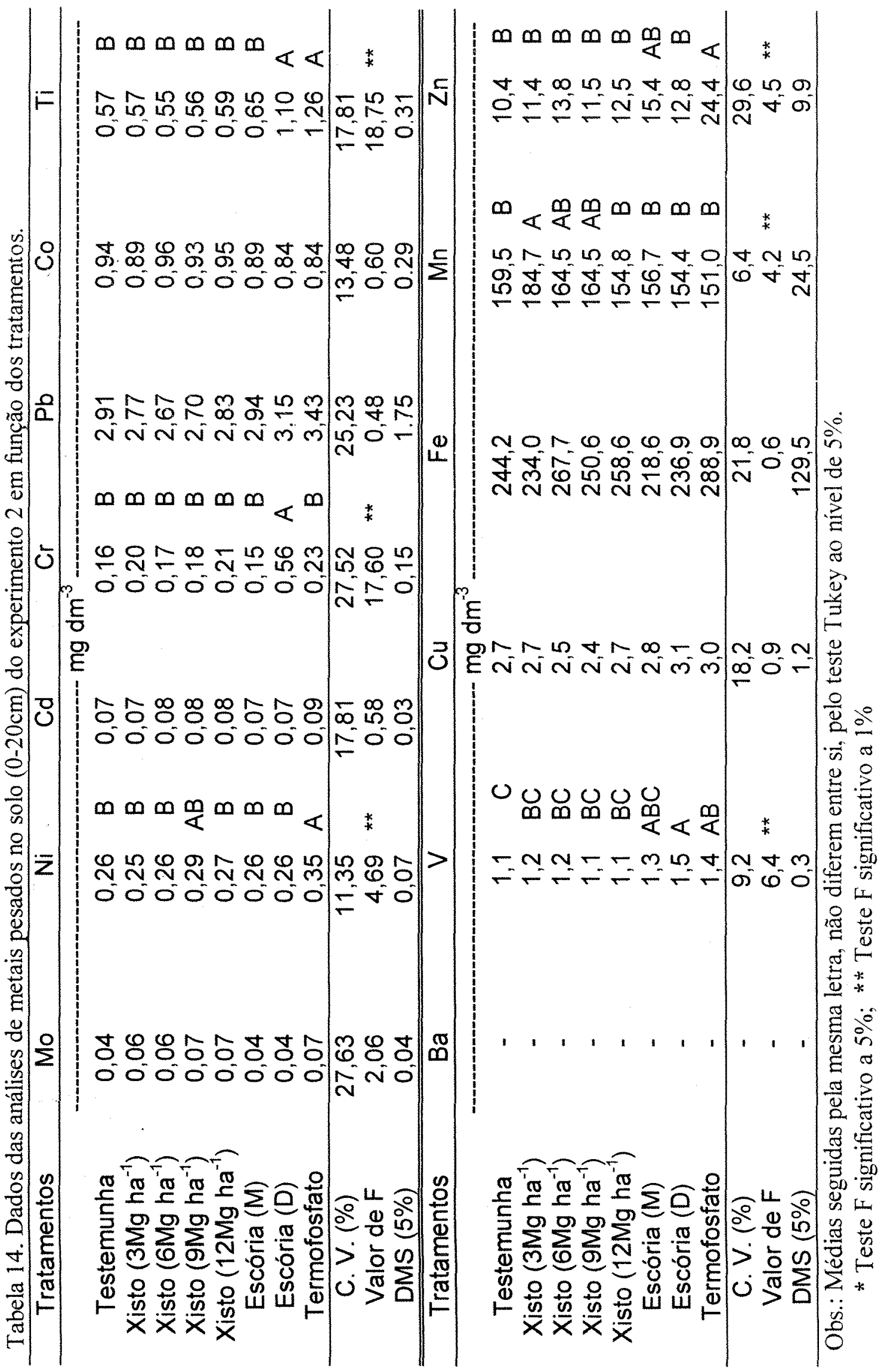


Agency (EPA). Comparando-se os dados apresentados por Wallce Wallace (1994) (Tabela 2), com a composição dos produtos (Tabela 5), verifica-se que, com exceção do Cr na escória da Dedini, os demais elementos da Tabela 5 apresentam-se abaixo da concentração máxima permissível nos resíduos segundo as normas da EPA, e mesmo com o Cr na escória da Dedini apresentando concentração mais elevada, na dose em que foi aplicada ao solo não atingiu a taxa anual máxima de aplicação no solo estabelecida pela EPA (Tabela 2).

Embora para a EPA a concentração de alguns metais apresentem-se abaixo do limite estabelecido, outros países apresentam norma mais severas como a apresentada por Rogalla (1998) de países europeus. Mas estas normas são estabelecidas basicamente em função ao uso dos lodos de esgoto, e estes são aplicados em quantidades mais elevadas no solo. As doses dos produtos usadas nestes experimentos, dificilmente atingiriam a taxa máxima anual de aplicação no solo, demonstrando então que estas doses não causariam prejuízos ao solo, não verificando-se assim, nenhuma contaminação por parte destes elementos. A concentração destes metais no solo conforme resultados das Tabelas 13 e 14, estão abaixo dos limites determinados pelas normas, tanto americana como de paises europeus, demonstrando que os mesmos podem ser usados sem danos ao solo e a natureza. Mais trabalhos com doses crescentes devem ser conduzidos com o objetivo de verificar-se até que ponto estes produtos podem ser utilizados, principalmente com relação ao xisto onde pouco se conhece sobre este produto, as escórias devido a seus efeitos corretivos, as doses usadas geralmente são calculadas em função da necessidade de calagem.

\subsection{Análises químicas do material vegetal}

\subsubsection{Avaliação nutricional do tomateiro}

Nas tabelas 15 e 16 são apresentados os teores de macronutrientes no limbo foliar respectivamente dos experimentos 1 e 2, e nas tabelas 17 e 18 os de micronutrientes. 
Através dos resultados das tabelas 15 e 16, observa-se que não houve alterações significativas nos teores foliares de fósforo, potássio, cálcio e magnésio em função da aplicação dos tratamentos, quando comparados com a testemunha. $O$ nitrogênio apresentou reduções nos teores foliares em função dos tratamentos, assim com $9 \mathrm{Mg} \mathrm{ha}^{-1}$ de xisto, ocorreu significância em relação a testemunha, no experimento 2 .

Tabela 15. Teores de macronutrientes no limbo foliar do tomateiro em função dos tratamentos (Experimento 1).

\begin{tabular}{|c|c|c|c|c|c|c|}
\hline Tratamentos & $\mathrm{N}$ & $\mathrm{P}$ & $\mathrm{K}$ & $\mathrm{Ca}$ & $\mathrm{Mg}$ & $\mathrm{S}$ \\
\hline & \multicolumn{6}{|c|}{ - $\mathrm{g} \mathrm{kg}^{-1}$} \\
\hline Testemunha & 34,6 & 6,5 & 47,9 & 41,5 & 7,8 & $6,8 \mathrm{BCD}$ \\
\hline Xisto $\left(3 \mathrm{Mg} \mathrm{ha}^{-1}\right)$ & 34,7 & 5,9 & 44,3 & 39,8 & 8,0 & 7,3 $\mathrm{ABCD}$ \\
\hline Xisto $\left(6 \mathrm{Mg} \mathrm{ha}{ }^{-1}\right)$ & 32,0 & 5,0 & 40,0 & 38,5 & 7,4 & $7,8 \mathrm{ABC}$ \\
\hline Xisto $\left(9 \mathrm{Mg} \mathrm{ha}{ }^{-1}\right)$ & 33,3 & 5,3 & 46,9 & 42,6 & 7,8 & $8,1 \mathrm{AB}$ \\
\hline Xisto $\left(12 \mathrm{Mg} \mathrm{ha}^{-1}\right)$ & 33,6 & 5,3 & 46,9 & 39,8 & 7,6 & $8,3 \mathrm{~A}$ \\
\hline Escória (M) & 31,5 & 4,8 & 43,7 & 37,2 & 8,1 & $\mathrm{CD}$ \\
\hline Escória (D) & 33,7 & 5,2 & 44,7 & 40,6 & 8,1 & 7,0 ABCD \\
\hline Termofosfato & 32,4 & 4,3 & 43,9 & 38,8 & 7,8 & 6,3 \\
\hline C. V. $(\%)$ & 4,4 & 22,8 & 13,1 & 11,5 & 8,6 & 8,6 \\
\hline Valor de F & $2,5 *$ & 1,2 & 0,7 & 0,6 & 0,5 & $5,7 * *$ \\
\hline DMS $(5 \%)$ & 3,5 & 2,9 & 13,9 & 10,9 & 1,6 & 1,4 \\
\hline
\end{tabular}

Obs.: Médias seguidas pela mesma letra, não diferem entre si, pelo teste Tukey ao nivel de $5 \%$;

* Teste F significativo a 5\%; ** Teste F significativo a $1 \%$

Ocorreu aumentos nos teores foliares de enxofre em função das doses de xisto, sendo que a maior dose apresentou-se significativamente diferente em relação à testemunha nos dois experimentos. A elevação nos teores nas folhas é reflexo de sua maior disponibilidade no solo. Por outro lado, o termofosfato apresentou reduções nos teores desse nutriente nas folhas, mostrando significância em relação aos tratamentos com as doses mais elevadas de xisto, mas não apresentou diferença significativa quando comparado à testemunha. As escórias (Mannesman e Dedini) não apresentaram diferenças significativas para esse nutriente quando comparadas à testemunha.

Com relação aos micronutrientes (Tabelas 17 e 18), não houve alterações significativas. Autores, como Fox et al. (1967), Plucnett (1972) e Elawad \& Green (1979), citam que o Si aumenta o poder de oxidação das raizes tornando menor a toxidez 
de Fe e Mn. Portanto, esperava-se maior redução nos teores foliares de Mn com a aplicação do xisto, principalmente no experimento 1, onde não foi aplicado este elemento via foliar. As escória também não apresentaram reduções no teor de Mn nas folhas com a elevação do valor $\mathrm{pH}$ do solo, isso ocorreu devido a elevada concentração deste elemento em suas composições.

Tabela 16. Teores de macronutrientes no limbo foliar do tomateiro em função dos tratamentos (Experimento 2).

\begin{tabular}{|c|c|c|c|c|c|c|}
\hline Tratamentos & $\mathrm{N}$ & $\mathrm{P}$ & $\mathrm{K}$ & $\mathrm{Ca}$ & $\mathrm{Mg}$ & $\mathrm{S}$ \\
\hline & \multicolumn{6}{|c|}{$\mathrm{g} \mathrm{kg}^{-1}$} \\
\hline Testemunha & $40,8 \mathrm{~A}$ & 4,3 & 29,0 & 36,1 & 4,4 & $6,1 \mathrm{BC}$ \\
\hline Xisto $\left(3 \mathrm{Mg} \mathrm{ha}^{-1}\right)$ & $36,7 \mathrm{AB}$ & 4,6 & 28,3 & 40,0 & 4,5 & $6,9 \mathrm{ABC}$ \\
\hline Xisto $\left(6 \mathrm{Mg} \mathrm{ha}^{-1}\right)$ & $38,3 \mathrm{AB}$ & 4,7 & 31,5 & 42,6 & 4,6 & $7,6 \mathrm{AB}$ \\
\hline Xisto $\left(9 \mathrm{Mg} \mathrm{ha}{ }^{-1}\right)$ & $35,5 \quad \mathrm{~B}$ & 4,4 & 31,1 & 38,0 & 4,3 & $7,6 \mathrm{AB}$ \\
\hline Xisto $\left(12 \mathrm{Mg} \mathrm{ha}^{-1}\right)$ & $39,6 \mathrm{AB}$ & 4,5 & 30,5 & 39,6 & 4,7 & $8,0 \mathrm{~A}$ \\
\hline Escória (M) & $37,2 \mathrm{AB}$ & 4,4 & 28,7 & 40,7 & 4,5 & $6,9 \mathrm{ABC}$ \\
\hline Escória (D) & $39,3 \mathrm{AB}$ & 4,2 & 27,4 & 38,8 & 4,6 & $6,3 \mathrm{BC}$ \\
\hline Termofosfato & $37,7 \mathrm{AB}$ & 4,1 & 30,4 & 39,3 & 4,5 & 5,5 \\
\hline C. V. $(\%)$ & 5,4 & 8,8 & 13,9 & 11,2 & 9,4 & 10,1 \\
\hline Valor de F & $2,8 *$ & 1,0 & 0,5 & 0,8 & 0,4 & $6,1 * *$ \\
\hline DMS $(5 \%)$ & 4,9 & 0,9 & 9,7 & 10,4 & 1,0 & 1,6 \\
\hline
\end{tabular}

Obs.: Médias seguidas pela mesma letra, não diferem entre si, pelo teste Tukey ao nível de $5 \%$;

* Teste F significativo a $5 \% ; \quad * *$ Teste $\mathrm{F}$ significativo a $1 \%$

Tabela 17. Teores de micronutrientes no limbo foliar do tomateiro em função dos tratamentos (Experimento 1).

\begin{tabular}{|c|c|c|c|c|c|}
\hline Tratamentos & $\mathrm{B}$ & $\mathrm{Cu}$ & $\mathrm{Fe}$ & $\mathrm{Mn}$ & $\mathrm{Zn}$ \\
\hline & $-\cdots$ & & $\mathrm{mg} \mathrm{kg}$ & & \\
\hline Testemunha & 91,0 & 541,3 & 161,5 & 105,0 & 16,3 \\
\hline Xisto (3Mg ha $\left.\mathrm{M}^{-1}\right)$ & 86,5 & 548,5 & 160,0 & 83,3 & 17,8 \\
\hline Xisto $\left(6 \mathrm{Mg} \mathrm{ha}^{-1}\right)$ & 81,5 & 600,0 & 158,8 & 102,8 & 16,3 \\
\hline Xisto (9Mg ha $\left.{ }^{-1}\right)$ & 80,5 & 534,8 & 168,8 & 100,3 & 15,8 \\
\hline Xisto (12 $\left.\mathrm{Mg} \mathrm{ha}^{-1}\right)$ & 86,5 & 639,0 & 179,8 & 95,0 & 14,5 \\
\hline Escória (M) & 69,8 & 563,3 & 201,8 & 90,5 & 15,5 \\
\hline Escória (D) & 79,0 & 553,0 & 187,3 & 74,5 & 15,0 \\
\hline Termofosfato & 89,8 & 487,5 & 190,3 & 95,0 & 17,0 \\
\hline C. V. $(\%)$ & 11,1 & 22,4 & 29,2 & 19,3 & 16,0 \\
\hline Valor de F & 2,2 & 0,5 & 0,4 & 1,3 & 0,7 \\
\hline DMS $(5 \%)$ & 21,8 & 296,8 & 122,1 & 42,7 & 6,1 \\
\hline
\end{tabular}

Obs.: Médias seguidas pela mesma letra, não diferem entre si, pelo teste Tukey ao nível de $5 \%$.

* Teste F significativo a 5\%; ** Teste F significativo a $1 \%$ 
Tabela 18. Teores de micronutrientes no limbo foliar do tomateiro em função dos tratamentos (Experimento 2).

\begin{tabular}{|c|c|c|c|c|c|}
\hline Tratamentos & $\mathrm{B}$ & $\mathrm{Cu}$ & $\mathrm{Fe}$ & $\mathrm{Mn}$ & $\mathrm{Zn}$ \\
\hline & $\ldots$ & $-4-\infty$ & $\mathrm{ng} \mathrm{kg}^{-1}$ & & \\
\hline Testemunha & 429,0 & 1014,8 & 406,0 & 802,5 & 75,8 \\
\hline Xisto $\left(3 \mathrm{Mg} \mathrm{ha}^{-1}\right)$ & 432,0 & 1064,5 & 431,0 & 875,3 & 83,4 \\
\hline Xisto (6Mg ha $\left.{ }^{-1}\right)$ & 488,5 & 1105,8 & 418,8 & 929,8 & 90,3 \\
\hline Xisto (9Mg ha $\left.{ }^{-1}\right)$ & 401,8 & 1054,8 & 379,5 & 876,0 & 82,8 \\
\hline Xisto $\left(12 \mathrm{Mg} \mathrm{ha}^{-1}\right)$ & 394,0 & 1021,3 & 482,0 & 836,8 & 73,0 \\
\hline Escória (M) & 453,5 & 1007,0 & 350,0 & 854,5 & 77,0 \\
\hline Escória (D) & 358,3 & 904,5 & 350,8 & 832,5 & 72,2 \\
\hline Termofosfato & 412,5 & 1121,5 & 367,5 & 851,0 & 82,2 \\
\hline C. V. $(\%)$ & 15,81 & 14,97 & 24,20 & 15,41 & 22,23 \\
\hline Valor de F & 1,41 & 0,76 & 0,89 & 0,33 & 0,48 \\
\hline DMS (5\%) & 157,9 & 368,2 & 228,6 & 313,3 & 419,8 \\
\hline
\end{tabular}

Obs.: Médias seguidas pela mesma letra, não diferem entre si, pelo teste Tukey ao nível de $5 \%$.

* Teste F significativo a 5\%; ** Teste F significativo a $1 \%$

Nas tabelas 19 e 20 são apresentados os teores de macronutrientes nos peciolos do tomateiro respectivamente dos experimentos 1 e 2 , e nas tabelas 21 e 22 os de micronutrientes.

Tabela 19. Teores de macronutrientes nos pecíolos do tomateiro em função dos tratamentos (Experimento 1).

\begin{tabular}{|c|c|c|c|c|c|c|}
\hline Tratamentos & $\mathrm{N}$ & $\mathrm{P}$ & $\mathrm{K}$ & $\mathrm{Ca}$ & $\mathrm{Mg}$ & $S$ \\
\hline & $-\cdots$ & $-\cdots$ & $-\cdots$ & & & $-\cdots$ \\
\hline Testemunha & 13,5 & $3,8 \mathrm{~A}$ & 35,1 & 27,0 & 6,2 & $2,8 \quad \mathrm{BC}$ \\
\hline Xisto $\left(3 \mathrm{Mg} \mathrm{ha}^{-1}\right)$ & 13,5 & $3,3 \mathrm{AB}$ & 27,2 & 26,2 & 5,6 & $3,1 \quad \mathrm{BC}$ \\
\hline Xisto $\left(6 \mathrm{Mg} \mathrm{ha} \mathrm{a}^{-1}\right)$ & 13,9 & $3,2 \mathrm{AB}$ & 22,5 & 25,3 & 5,2 & $3,5 \mathrm{ABC}$ \\
\hline Xisto $\left(9 \mathrm{Mg} h \mathrm{a}^{-1}\right)$ & 14,7 & $3,0 \mathrm{AB}$ & 30,9 & 27,1 & 6,1 & $4,1 \mathrm{AB}$ \\
\hline Xisto $\left(12 \mathrm{Mg} \mathrm{ha}^{-1}\right)$ & 14,4 & $2,9 \mathrm{AB}$ & 30,6 & 26,2 & 5,8 & $4,5 \mathrm{~A}$ \\
\hline Escória (M) & 13,7 & $2,2 \mathrm{~B}$ & 23,3 & 23,9 & 5,2 & $2,3 \quad \mathrm{C}$ \\
\hline Escória (D) & 14,6 & $2,8 \mathrm{AB}$ & 32,0 & 26,9 & 6,7 & $3,5 \mathrm{ABC}$ \\
\hline Termofosfato & 14,1 & 2,3 B & 32,6 & 25,1 & 6,3 & $2,8 \quad \mathrm{BC}$ \\
\hline C. V. $(\%)$ & 8,0 & 17,6 & 28,8 & 9,0 & 18,0 & 17,5 \\
\hline Valor de F & 0,7 & $3,8 * *$ & 1,1 & 0,9 & 1,0 & $6,3 * *$ \\
\hline DMS $(5 \%)$ & 2,7 & 1,2 & 19,9 & 5,5 & 2,5 & 1,3 \\
\hline
\end{tabular}

Obs.: Médias seguidas pela mesma letra, não diferem entre si, pelo teste Tukey ao nível de $5 \%$.

* Teste F significativo a $5 \%$; ** Teste F significativo a $1 \%$ 
Tabela 20. Teores de macronutrientes nos pecíolos do tomateiro em função dos tratamentos (Experimento 2).

\begin{tabular}{|c|c|c|c|c|c|c|}
\hline Tratamentos & $\mathrm{N}$ & $\mathrm{P}$ & $\mathrm{K}$ & $\mathrm{Ca}$ & $\mathrm{Mg}$ & $S$ \\
\hline & & & $---\mathrm{g} \mathrm{kg}$ & & & \\
\hline Testemunha & 14,0 & $4,3 \mathrm{AB}$ & $57,2 \mathrm{AB}$ & 32,4 & 5,6 & $2,3 \mathrm{ABC}$ \\
\hline Xisto $\left(3 \mathrm{Mg} h \mathrm{ha}^{-1}\right)$ & 13,6 & $4,7 \mathrm{AB}$ & $56,7 \mathrm{AB}$ & 32,7 & 5,3 & $2,2 \mathrm{ABC}$ \\
\hline Xisto $\left(6 \mathrm{Mg} \mathrm{ha} a^{-1}\right)$ & 14,2 & $5,4 \mathrm{~A}$ & $59,6 \mathrm{~A}$ & 33,0 & 5,2 & $2,6 \mathrm{AB}$ \\
\hline Xisto $\left(9 \mathrm{Mg} \mathrm{ha}{ }^{-1}\right)$ & 13,9 & $5,0 \mathrm{~A}$ & $58,4 \mathrm{~A}$ & 32,6 & 5,3 & $2,8 \mathrm{~A}$ \\
\hline Xisto $\left(12 \mathrm{Mg} \mathrm{ha}^{-1}\right)$ & 13,5 & $4,7 \mathrm{AB}$ & $55,4 \mathrm{AB}$ & 30,7 & 5,2 & $2,8 \mathrm{~A}$ \\
\hline Escória (M) & 13,7 & $4,4 \mathrm{AB}$ & $48,0 \quad \mathrm{~B}$ & 31,8 & 5,1 & $2,2 \quad \mathrm{BC}$ \\
\hline Escória (D) & 13,6 & $4,5 \mathrm{AB}$ & $55,8 \mathrm{AB}$ & 31,8 & 5,4 & $2,2 \mathrm{ABC}$ \\
\hline Termofosfato & 13,8 & $3,7 \quad \mathrm{~B}$ & $58,8 \mathrm{AB}$ & 33,6 & 5,8 & 1,8 \\
\hline C. V. $(\%)$ & 4,93 & 12,80 & 7,74 & 7,74 & 11,21 & 11,53 \\
\hline Valor de F & 0,54 & $2,95 *$ & $3,02 *$ & 0,49 & 0,61 & $5,74 * *$ \\
\hline DMS $(5 \%)$ & 1,6 & 1,3 & 9,9 & 5,9 & 1,4 & 0,6 \\
\hline
\end{tabular}

Obs.: Médias seguidas pela mesma letra, não diferem entre si, pelo teste Tukey ao nível de $5 \%$.

* Teste F significativo a $5 \%$; ** Teste $\mathrm{F}$ significativo a $1 \%$

Nos pecíolos as alterações dos macronutrientes (Tabelas 19 e 20) apresentaram o mesmo comportamento em relação aos observados no limbo foliar, mostrando que a principal alteração foi o aumento nos teores de enxofre em função da aplicação do xisto retortado.

O nitrogênio não apresentou diferenças significativas, mas observa-se redução com a aplicação dos tratamentos no experimento 2, mas não significativa. Assim, como no limbo foliar, o fósforo apresentou menores teores no tratamento com termofosfato, sendo significativo quando comparado à testemunha no experimento 1 . Prochnow (1996), demonstrou que as fontes menos solúveis de fósforo, apresentam uma menor disponibilidade deste elemento, as plantas com ciclo de vida rápido, pois não haveria tempo suficiente para seu total aproveitamento.

Os teores de fósforo nos pecíolos também apresentaram diferenças significativas do tratamento com termofosfato, com relação as maiores doses de xisto no experimento 2, pois o tratamento com xisto apresentou pequeno aumento nos teores foliares deste elemento. Este aumento não é significativo, quando comparado à testemunha, e também não foi verificado no experimento 1 , mas reforça a idéia da maior 
disponibilidade deste elemento em função da aplicação de silicatos Taylor (1961); Obihara \& Russel (1972) e Smith \& Sanches (1980).

Tabela 21. Teores de micronutrientes nos pecíolos do tomateiro em função dos tratamentos (Experimento 1).

\begin{tabular}{|c|c|c|c|c|c|c|}
\hline Tratamentos & $\mathrm{B}$ & $\mathrm{Cu}$ & $\mathrm{Fe}$ & $\mathrm{Mn}$ & & $\mathrm{Zn}$ \\
\hline & $\cdots$ & & $\mathrm{g} \mathrm{kg}^{-1}$ & & & \\
\hline Testemunha & 49,3 & 111,0 & 59,0 & 67,8 & $A B$ & 40,3 \\
\hline Xisto $\left(3 \mathrm{Mg} \mathrm{ha}^{-1}\right)$ & 43,5 & 109,8 & 55,0 & 54,0 & $\mathrm{AB}$ & 34,0 \\
\hline Xisto $\left(6 \mathrm{Mg}\right.$ ha $\left.{ }^{-1}\right)$ & 49,3 & 109,3 & 57,8 & 55,0 & $\mathrm{AB}$ & 30,0 \\
\hline Xisto $\left(9 \mathrm{Mg} \mathrm{ha} \mathrm{h}^{-1}\right)$ & 50,5 & 114,0 & 61,5 & 70,0 & $\mathrm{AB}$ & 36,3 \\
\hline Xisto $\left(12 \mathrm{Mg} \mathrm{ha}{ }^{-1}\right)$ & 52,5 & 113,5 & 61,0 & 80,0 & $\mathrm{~A}$ & 31,5 \\
\hline Escória (M) & 43,8 & 91,0 & 58,8 & 46,8 & $\mathrm{AB}$ & 28,0 \\
\hline Escória (D) & 50,3 & 114,8 & 60,8 & 60,5 & B & 30,5 \\
\hline Termofosfato & 48,0 & 87,3 & 54,0 & 57,5 & $\mathrm{AB}$ & 34,5 \\
\hline C. V. $(\%)$ & 12,4 & 26,1 & 20,0 & 20,4 & & 23,4 \\
\hline Valor de $\mathrm{F}$ & 1,1 & 0,6 & 0,2 & 2,9 & $*$ & 1,0 \\
\hline DMS (5\%) & 14,2 & 65,7 & 27,7 & 29,8 & & 18,4 \\
\hline
\end{tabular}

Obs.: Médias seguidas pela mesma letra, não diferem entre si, pelo teste Tukey ao nível de $5 \%$.

* Teste $\mathrm{F}$ significativo a $5 \%$; ** Teste $\mathrm{F}$ significativo a $1 \%$

Tabela 22. Teores de micronutrientes nos pecíolos do tomateiro em função dos tratamentos (Experimento 2).

\begin{tabular}{crrrrr}
\hline Tratamentos & $\mathrm{B}$ & $\mathrm{Cu}$ & $\mathrm{Fe}$ & $\mathrm{Mn}$ & $\mathrm{Zn}$ \\
\hline & 59,3 & 138,8 & 111,8 & 131,5 & 186,8 \\
Testemunha & 61,0 & 134,8 & 94,8 & 126,8 & 172,5 \\
${\text { Xisto }\left(3 \mathrm{Mg} \mathrm{ha}^{-1}\right)}^{-1}$ & 61,8 & 70,8 & 116,0 & 180,8 \\
${\text { Xisto }\left(6 \mathrm{Mg} \mathrm{ha}^{-1}\right)}^{-1}$ & 57,0 & 133,5 & 75,8 & 114,5 & 172,0 \\
Xisto $\left(9 \mathrm{Mg} \mathrm{ha}^{-1}\right)$ & 59,5 & 124,8 & 67,8 & 109,8 & 152,5 \\
Xisto $\left(12 \mathrm{Mg} \mathrm{ha}^{-1}\right)$ & 56,5 & 106,5 & 74,3 & 110,8 & 151,3 \\
Escória (M) & 58,5 & 112,8 & 73,8 & 116,3 & 162,3 \\
Escória (D) & 66,3 & 117,5 & 104,8 & 121,0 & 180,0 \\
Termofosfato & 62,8 & 148,5 & 37,59 & 12,66 & 18,44 \\
\hline C. V. (\%) & 14,91 & 20,91 & 1,15 & 1,04 & 0,71 \\
Valor de F & 0,51 & 1,15 & 32,5 & 35,5 & 74,2 \\
DMS (5\%) & 21,2 & 63,1 & $\mathrm{mg} \mathrm{h}^{-1}$ &
\end{tabular}

Obs.: Médias seguidas pela mesma letra, não diferem entre si, pelo teste Tukey ao nivel de $5 \%$.

* Teste F significativo a 5\%; ** Teste F significativo a $1 \%$ 
Quanto aos teores de micronutrientes nos pecíolos (Tabelas 21 e 22), a única diferença estatística verificada foi o manganês no experimento 1. Observa-se, que a maior dose de xisto difere da escória da Dedini, isto deveria ao fato da escoria ter apresentado uma elevação no valor $\mathrm{pH}$ do solo, enquanto que o xisto causou uma pequena redução, refletindo portanto, na disponibilidade deste elemento e consequentemente no seu teor no pecíolo. Assim como no limbo foliar (Fox et al., 1967; Plucnett, 1972; e Elawad \& Green, 1979), não foi observado o Si aumentando o poder de oxidação das raizes tornando menor a toxidez de Fe e Mn, o que verifica-se é que a disponibilidade do $\mathrm{Mn}$ é mais influenciada pelo valor $\mathrm{pH}$. No experimento 2 , isto não foi verificado provavelmente devido as constantes aplicações deste elemento em pulverizações.

Os demais micronutrientes não apresentaram alterações significativas nos resultados.

\subsubsection{Silício no tomateiro}

Os resultados analíticos de silício nas amostras foliares (limbo e pecíolo) estão apresentados nas tabelas 23 e 24.

Tabela 23. Análises de silício, no limbo foliar e pecíolos do Experimento 1.

\begin{tabular}{|c|c|c|c|c|c|c|c|c|}
\hline \multirow[b]{2}{*}{ Tratamentos } & \multicolumn{4}{|c|}{ Método azul } & \multicolumn{4}{|c|}{ Método amarelo } \\
\hline & \multicolumn{2}{|c|}{ Limbo } & \multicolumn{2}{|c|}{ Pecíolo } & \multicolumn{2}{|c|}{ Limbo } & \multicolumn{2}{|c|}{ Pecíolo } \\
\hline & -- & & & $-\mathrm{g}$ & & - & 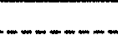 & $\cdots$ \\
\hline Testemunha & 1,27 & B & 0,29 & B & 0,18 & $\mathrm{C}$ & 0,16 & $\mathrm{BC}$ \\
\hline Xisto $\left(3 \mathrm{Mg} \mathrm{ha}^{-1}\right)$ & 1,33 & B & 0,28 & B & 0,78 & $\mathrm{BC}$ & 0,38 & $\mathrm{AB}$ \\
\hline Xisto $\left(6 \mathrm{Mg} \mathrm{ha}^{-1}\right)$ & 1,60 & $\mathrm{AB}$ & 0,38 & $\mathrm{AB}$ & 1,04 & $A B$ & 0,28 & $\mathrm{BC}$ \\
\hline Xisto $\left(9 \mathrm{Mg} \mathrm{ha}^{-1}\right)$ & 1,60 & $\mathrm{AB}$ & 0,55 & A & 1,19 & $\mathrm{AB}$ & 0,35 & $\mathrm{ABC}$ \\
\hline Xisto $\left(12 \mathrm{Mg} \mathrm{ha}^{-1}\right)$ & 1,65 & $\mathrm{AB}$ & 0,56 & A & 0,92 & $\mathrm{AB}$ & 0,36 & $\mathrm{AB}$ \\
\hline Escória (M) & 1,80 & A & 0,38 & $\mathrm{AB}$ & 1,51 & A & 0,53 & A \\
\hline Escória (D) & 1,64 & $\mathrm{AB}$ & 0,29 & B & 1,16 & $\mathrm{AB}$ & 0,39 & $\mathrm{AB}$ \\
\hline Termofosfato & 1,37 & $\mathrm{~B}$ & 0,25 & $\mathrm{~B}$ & 1,08 & $\mathrm{AB}$ & 0,11 & $\mathrm{C}$ \\
\hline C. V. $(\%)$ & 11,23 & & 22,41 & & 29,08 & & 32,44 & \\
\hline Valor de F & 4,73 & ** & 8,46 & ** & 7,34 & $* *$ & 6,79 & ** \\
\hline DMS $(5 \%)$ & 0,41 & & 0,20 & & 0,68 & & 0,25 & \\
\hline
\end{tabular}

Obs.: Médias seguidas pela mesma letra, não diferem entre si, pelo teste Tukey ao nível de $5 \%$.

* Teste F significativo a $5 \%$; $* *$ Teste $\mathrm{F}$ significativo a $1 \%$ 
Tabela 24. Análises de silício, no limbo foliar e pecíolos do Experimento 2.

\begin{tabular}{|c|c|c|c|c|c|c|c|}
\hline \multirow[b]{2}{*}{ Tratamentos } & \multicolumn{4}{|c|}{ Método azul } & \multicolumn{3}{|c|}{ Método amarelo } \\
\hline & \multicolumn{2}{|c|}{ Limbo } & \multicolumn{2}{|c|}{ Pecíolo } & Limbo & \multicolumn{2}{|c|}{ Pecíolo } \\
\hline & -- & $\cdots-\cdots$ & & $-\mathrm{gk}$ & & & \\
\hline Testemunha & 1,84 & $\mathrm{C}$ & 0,49 & $\mathrm{C}$ & 2,27 & 0,42 & B \\
\hline Xisto $\left(3 \mathrm{Mg} \mathrm{ha} \mathrm{a}^{-1}\right)$ & 2,29 & $\mathrm{BC}$ & 0,54 & $\mathrm{C}$ & 3,13 & 0,76 & $\mathrm{AB}$ \\
\hline Xisto $\left(6 \mathrm{Mg} \mathrm{ha}{ }^{-1}\right)$ & 2,67 & $\mathrm{ABC}$ & 0,53 & $\mathrm{C}$ & 3,47 & 0,69 & $\mathrm{AB}$ \\
\hline Xisto $\left(9 \mathrm{Mg} \mathrm{ha}^{-1}\right)$ & 2,89 & $\mathrm{AB}$ & 0,98 & $\mathrm{AB}$ & 3,81 & 0,71 & $\mathrm{AB}$ \\
\hline Xisto (12Mg ha' $\left.{ }^{-1}\right)$ & 3,39 & A & 1,06 & A & 3,97 & 1,06 & A \\
\hline Escória (M) & 2,60 & $\mathrm{ABC}$ & 0,53 & $\mathrm{C}$ & 3,72 & 0,97 & A \\
\hline Escória (D) & 2,22 & $\mathrm{BC}$ & 0,57 & $B C$ & 3,21 & 0,91 & A \\
\hline Termofosfato & 2,50 & $\mathrm{BC}$ & 0,56 & $\mathrm{BC}$ & 3,05 & 0,82 & A \\
\hline C. V. $(\%)$ & 13,92 & & 26,98 & & 29,75 & 20,42 & \\
\hline Valor de F & 6,93 & ** & 6,50 & ** & 1,20 & 6,01 & ** \\
\hline DMS $(5 \%)$ & 0,84 & & 0,42 & & 2,35 & 0,38 & \\
\hline
\end{tabular}

Obs.: Médias seguidas pela mesma letra, não diferem entre si, pelo teste Tukey ao nível de $5 \%$.

* Teste $\mathrm{F}$ significativo a $5 \% ; * *$ Teste $\mathrm{F}$ significativo a $1 \%$

De uma maneira geral os tratamentos aumentaram os teores de silício nas folhas. No experimento 1, os maiores teores no limbo foliar ocorreram no tratamento com escória da Mannesman, diferindo da testemunha, no pecíolo apenas nos resultados pelo método amarelo este tratamento apresentou o teor maior, diferindo também da testemunha. Pelo método azul os tratamentos que apresentaram os maiores teores de silício nos pecíolos foram nas doses de 9 e $12 \mathrm{Mg} \mathrm{ha}^{-1}$ de xisto, diferindo da testemunha.

No experimento 2 as doses mais elevadas de xisto foram as que refletiram nos maiores teores do limbo foliar e pecíolo, diferindo significativamente da testemunha com exceção do teor de silício no limbo foliar determinado pelo método amarelo Os resultados se mostraram bem coerentes com os resultados de silício no solo, demonstrando maior fornecimento em função dos tratamentos. Segundo Ponnamperuma (1972), a disponibilidade de Si para as plantas decorre da sua dissolução no solo, e a concentração de ácido silícico na solução é essencialmente controlada pelo $\mathrm{pH}$ e dependente da reação de adsorção dos sesquióxidos. Portanto, como as escórias promoveram um aumento de $\mathrm{pH}$, é provável que nestas condições houve uma maior força de adsorção dos silicatos diminuindo sua disponibilidade como é observado principalmente no experimento 2. Nas figuras 2 e 3 são apresentadas as regressões 
polinomiais dos teores de silício nas plantas (limbo e pecíolo) em função das doses de xisto.

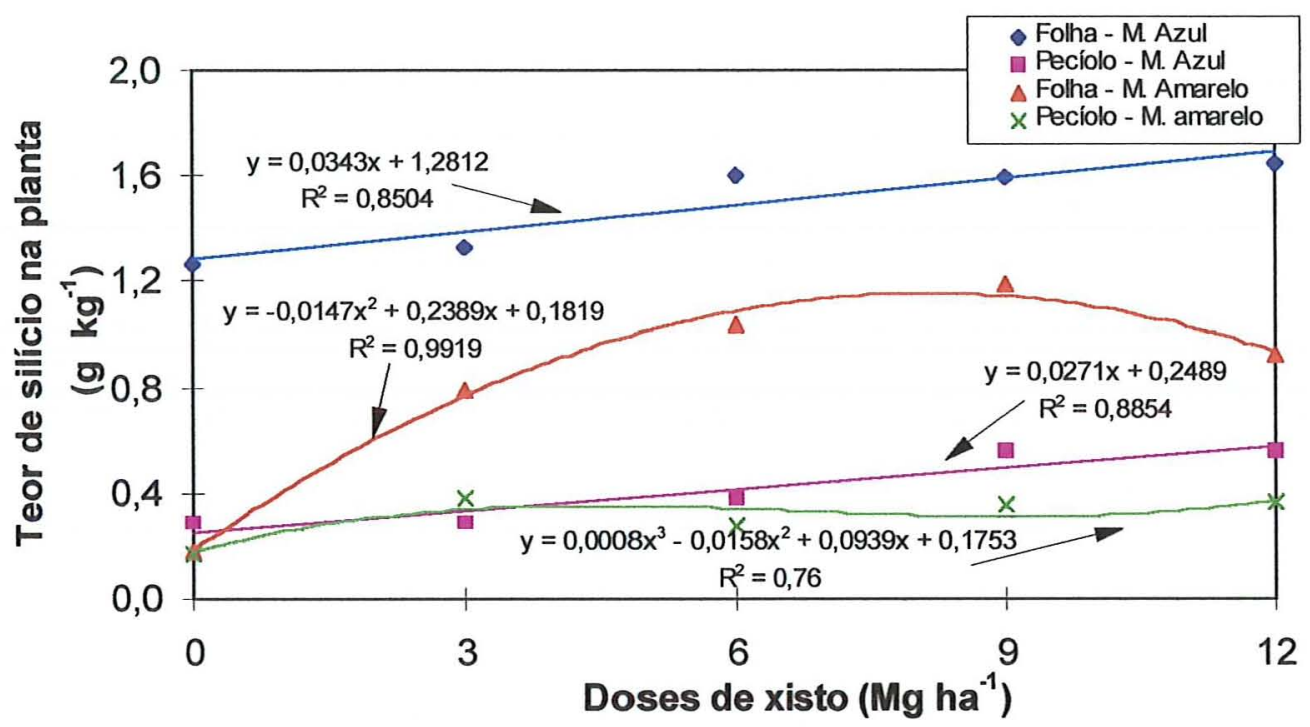

Figura 2. Regressão polinomial do silício na planta (limbo e pecíolo) em função das doses de xisto (Experimento 1).

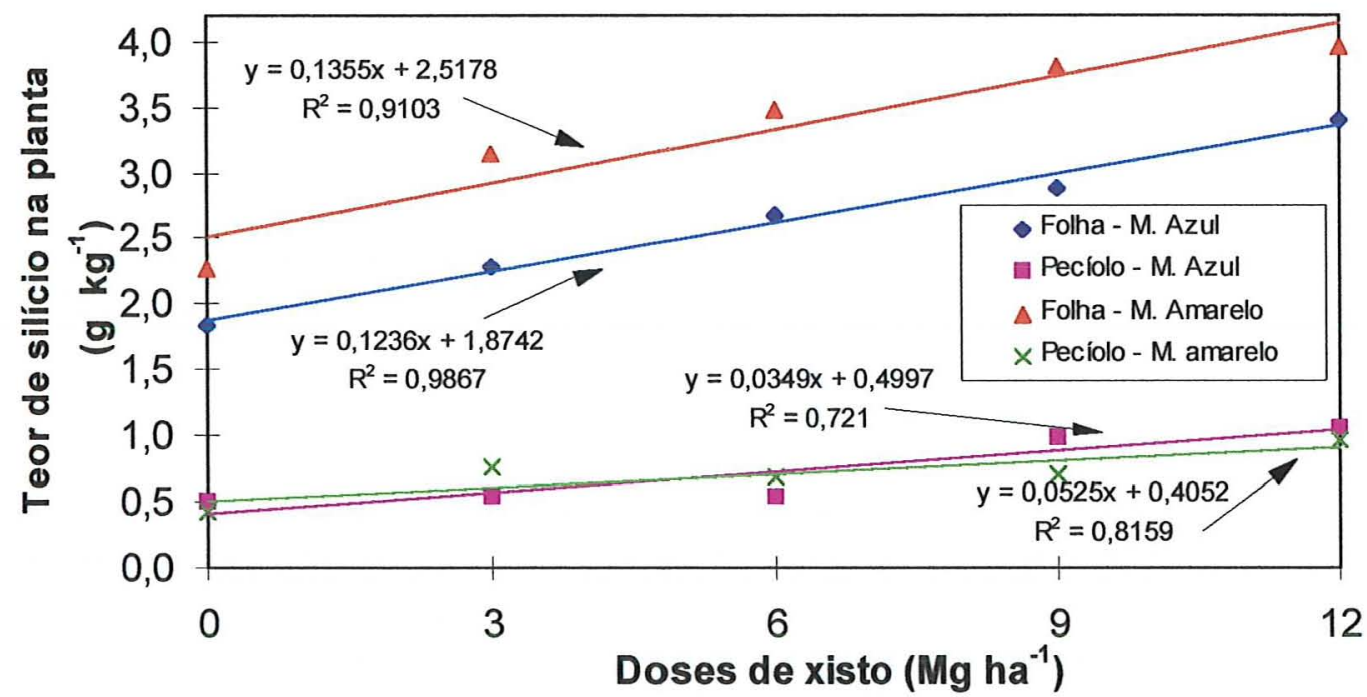

Figura 3. Regressão polinomial do silício na planta (limbo e pecíolo) em função das doses de xisto (Experimento 2).

Os métodos de análises se mostraram bem coerentes, mas o método amarelo apresentou-se bastante problemático, sendo necessário extremo cuidado analítico, procedendo-se várias repetições nas determinações, pois qualquer problema na 
amostra os resultados alteravam. A cor amarela é bastante influenciada pela cor residual do extrato, principalmente pela coloração verde da clorofila quando se verifica que a digestão não ocorreu completamente. $O$ método azul se mostrou mais simples e com resultados mais confiáveis.

\subsubsection{Metais pesados no tomateiro}

Nas tabelas 24 e 25 estão apresentados os resultados analíticos dos teores de metais pesados no limbo foliar das plantas do tomateiro respectivamente dos experimentos 1 e 2 e nas tabelas 26 e 27 os dos pecíolos.

As principais alterações verificadas nos teores de metais do limbo foliar foram devido ao aumentando no teor de molibdênio pelas escórias, apresentando diferenças significativas no experimento 2, e o titânio sofreu um aumento com a aplicação do xisto onde a dose de $3 \mathrm{Mg} \mathrm{ha}^{-1}$ diferiu da dose de $12 \mathrm{Mg} \mathrm{ha}^{-1}$ no experimento 1 .

O molibdênio foi o único elemento que apresentou diferenças significativas nos pecíolos no experimento 2, aumentando com a aplicação dos tratamentos. Alguns autores (Kilkelly \& Lindsay, 1982; Schwab et al., 1983; Stark \& Redente, 1990) citam que o Mo é um dos principais problemas nas plantas que creciam sobre o xisto retortado, constatando que sua concentração em forrageiras perecia ser o maior perigo ambiental, mas nas doses usadas neste experimento este elemento não verificou-se isto, o xisto em função da dose usada no experimento não apresentou alterações significativas no teor Mo nos tecidos da planta, sendo a concentração do Mo no xisto bem abaixo a concentração nas escórias que apresentaram valores mais elevados nos tecidos. O cádmio apresentou reduções em função da aplicação da escória da Mannesman e termofosfato, e aumentou com a aplicação do xisto no experimento 2 , fazendo com que estas escórias, embora com maior teor de Cd em sua composição, diferissem das maiores doses de xisto. De acordo com Kitashi \& Yamane (1987) o Cd forma complexos com hidróxidos, carbonatos e cloreto e sua disponibilidade é afetada pelo aumento do valor $\mathrm{pH}$. O bário 


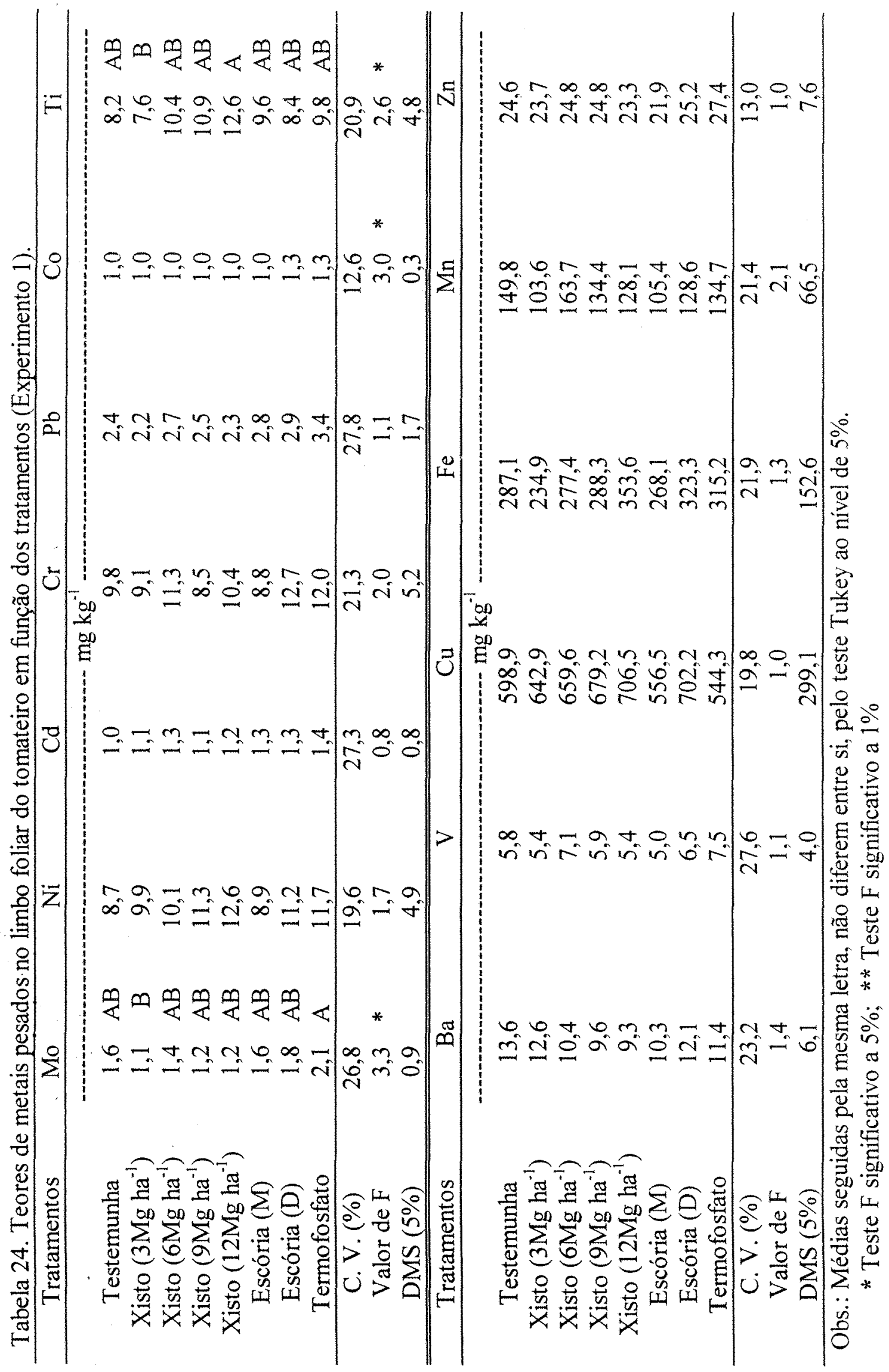




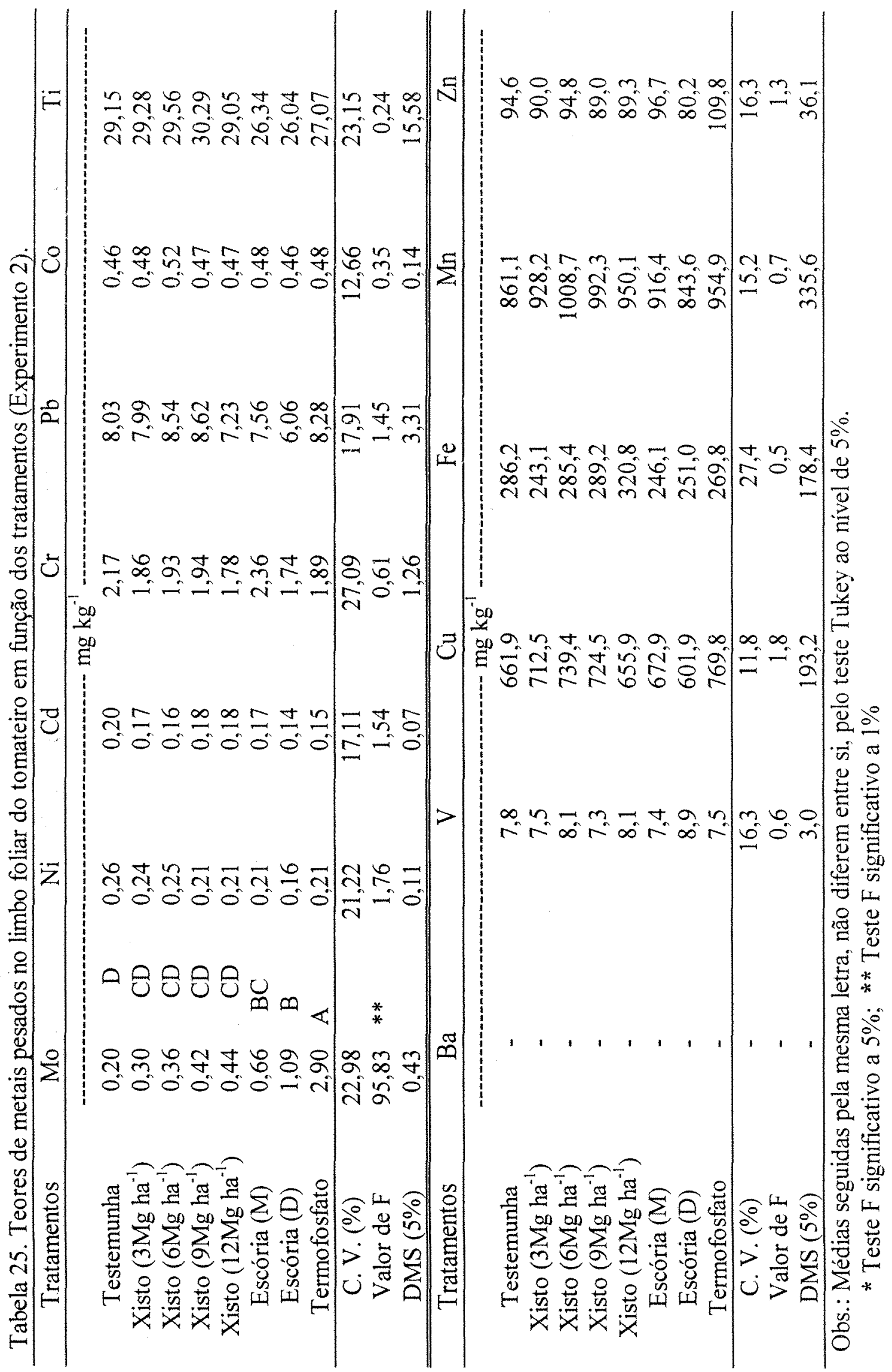




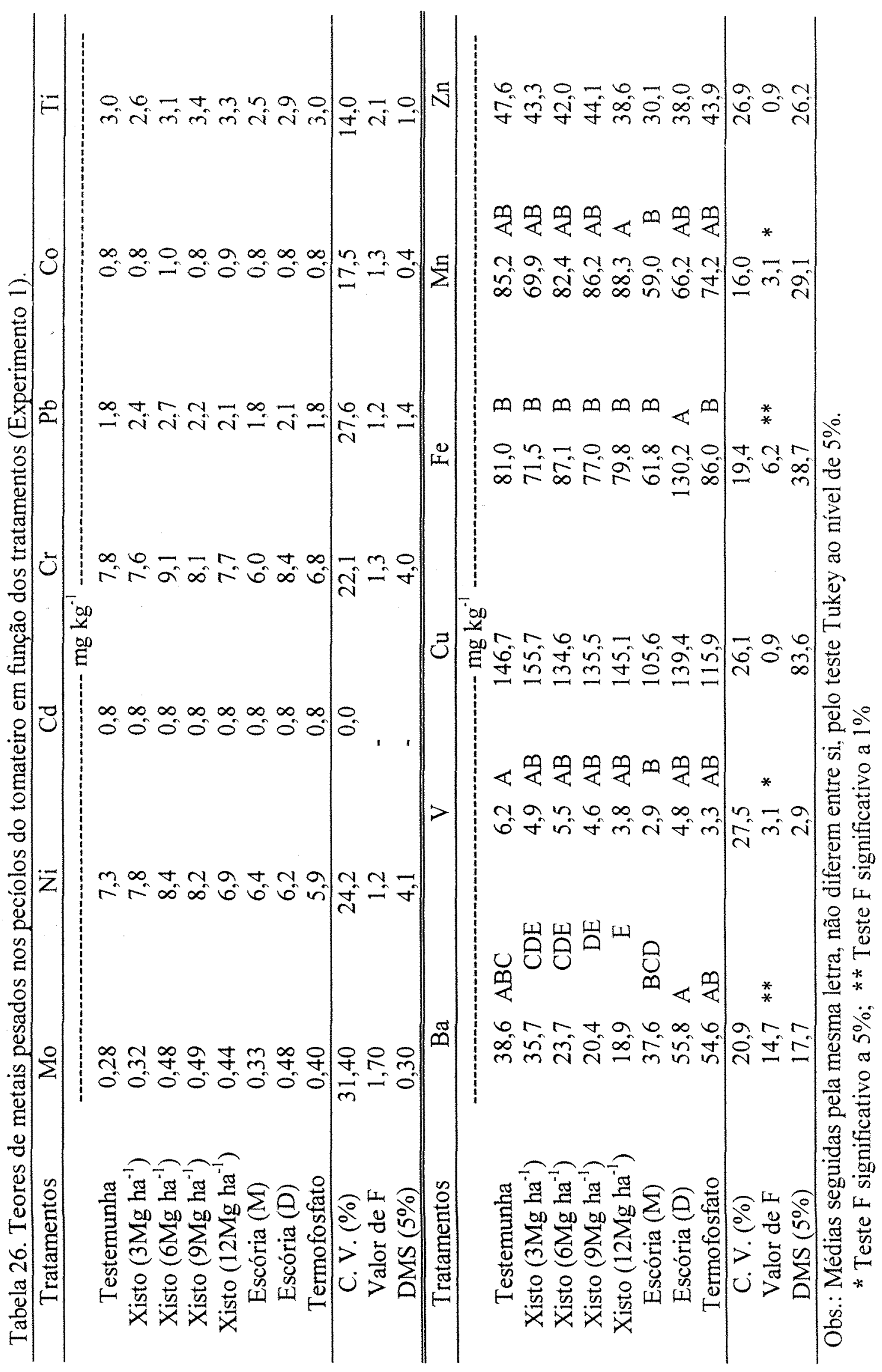




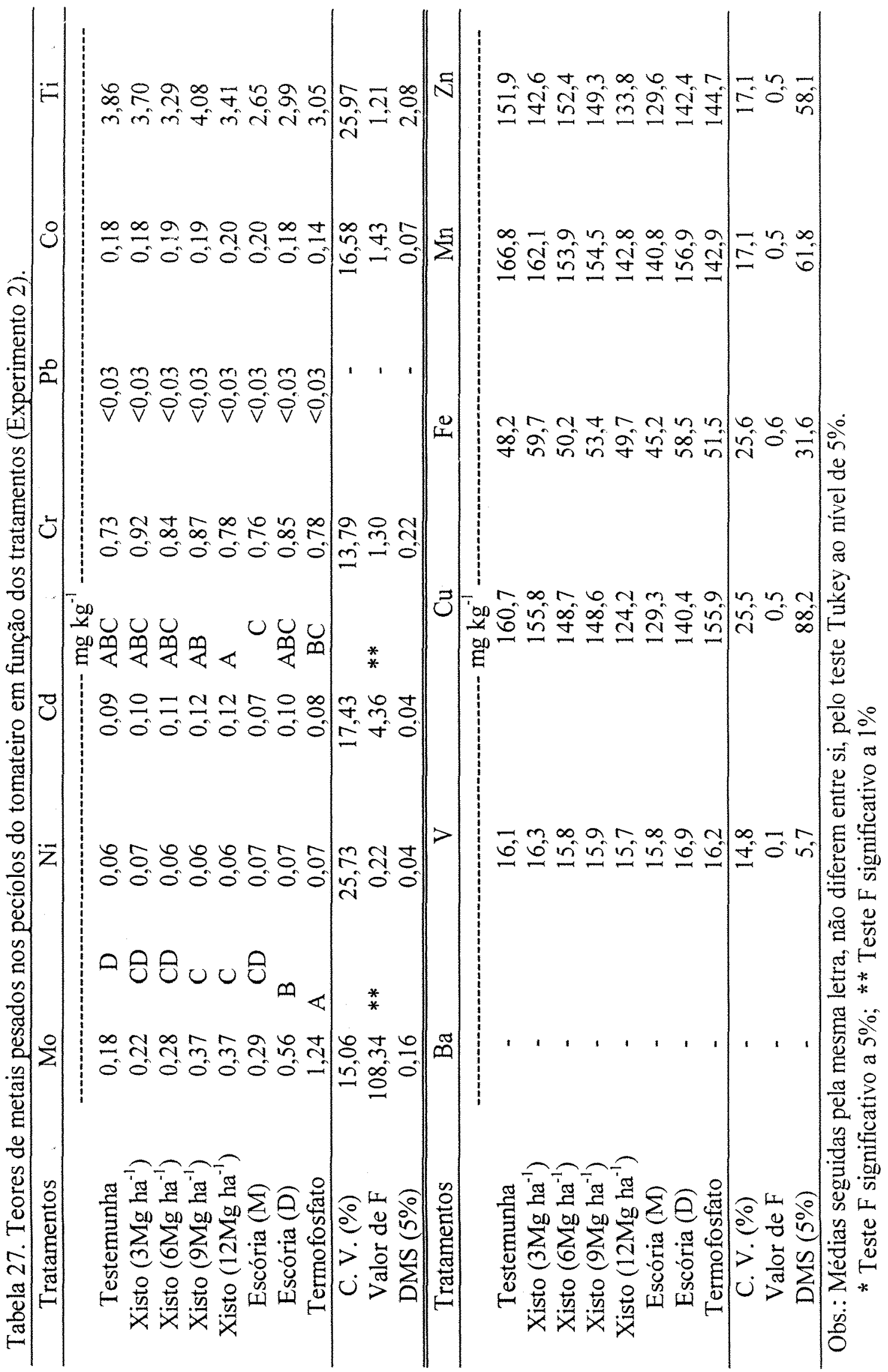


no experimento 1, teve elevação do seu teor em função dos tratamentos com a escória da Dedini e o termofosfato e o xisto reduziu, fazendo com que estes tratamentos diferissem significativamente. A redução do $\mathrm{Ba}$ em função da aplicação de xisto ocorreu devido a complexação deste metal pelo sulfato conforme comentado por Chaudry et al. (1977). O $\mathrm{Fe}$ apresentou teores mais elevados no tratamento com escória da Dedini, sendo significativo com relação aos demais tratamentos, provavelmente devido ao elevado teor deste elemento neste produto.

O Mn apresentou redução com a aplicação das escórias e aumentos com relação as doses de xisto sendo que a escória da Mannesman apresentou diferença significativa com a dose de $3 \mathrm{Mg} \mathrm{ha}^{-1}$ de xisto, no experimento 1 .

As escórias que apresentavam em suas composições concentrações maiores de titânio não provocaram alterações na concentração deste elemento nas folhas. O Cr embora também tenha uma concentração elevada nas escórias, principalmente a escória da Dedini, também não apresentou elevações significativas de seu teor nas folhas do tomateiro, pois este metal é precipitado a um valor $\mathrm{pH}$ acima de 5,5 deixando-o indisponível (Bartlett \& James, 1976).

\subsection{Análises microbiológicas}

Na Tabela 28 estão apresentados os resultados médios da quantidade de $\mathrm{CO}_{2}$ liberada pela análise de respirometria dos dois experimentos.

No experimento 1, não verificaram-se alterações significativas na liberação de $\mathrm{CO}_{2}$ entre os tratamentos. Através da figura 4 pode-se observar a evolução da liberação de $\mathrm{CO}_{2}$ no tempo do experimento 1 , e na figura 5 , são apresentados os resultados acumulados da liberação de $\mathrm{CO}_{2}$. 
Tabela 28. Resultados da liberação de $\mathrm{CO}_{2}$ em amostras de solos dos experimentos.

\begin{tabular}{|c|c|c|c|}
\hline \multirow[t]{2}{*}{ Tratamentos } & \multirow{2}{*}{$\begin{array}{c}\text { Experimento } 1 \\
\text { não ativado }\end{array}$} & \multicolumn{2}{|c|}{ Experimento 2} \\
\hline & & não ativado & ativado \\
\hline & & $\mathrm{CO}_{2} \mathrm{~g}^{-1}$ de solo & - \\
\hline Testemunha & 9,97 & 1,91 & $19,71 \mathrm{~A}$ \\
\hline Xisto $\left(3 \mathrm{Mg} \mathrm{ha}{ }^{-1}\right)$ & 10,36 & 2,02 & $18,65 \mathrm{AB}$ \\
\hline Xisto $\left(6 \mathrm{Mg} \mathrm{ha}^{-1}\right)$ & 9,52 & $2.36 \mathrm{ABC}$ & $19,74 \mathrm{~A}$ \\
\hline Xisto $\left(9 \mathrm{Mg} \mathrm{ha}^{-1}\right)$ & 10,46 & $2,34 \mathrm{ABC}$ & $18,45 \mathrm{AB}$ \\
\hline Xisto $\left(12 \mathrm{Mg} \mathrm{ha}^{-1}\right)$ & 9,42 & $2,67 \mathrm{AB}$ & $18,69 \mathrm{AB}$ \\
\hline Escória (M) & 9,20 & $2,81 \mathrm{~A}$ & $18,53 \mathrm{AB}$ \\
\hline Escória (D) & 9,66 & $2,16 \quad \mathrm{BC}$ & $17,57 \quad \mathrm{~B}$ \\
\hline Termofosfato & 10,53 & $2,48 \mathrm{ABC}$ & $18,30 \mathrm{AB}$ \\
\hline C. V. (\%) & 18,56 & 11,17 & 4,71 \\
\hline Valor de F & 0,31 & $5,62 * *$ & $2,67 *$ \\
\hline DMS (5\%) & 4,35 & 0,62 & 2,09 \\
\hline
\end{tabular}

Obs.: Médias seguidas pela mesma letra, não diferem entre si, pelo teste Tukey ao nível de $5 \%$.

* Teste F significativo a 5\%; ** Teste F significativo a 1\%

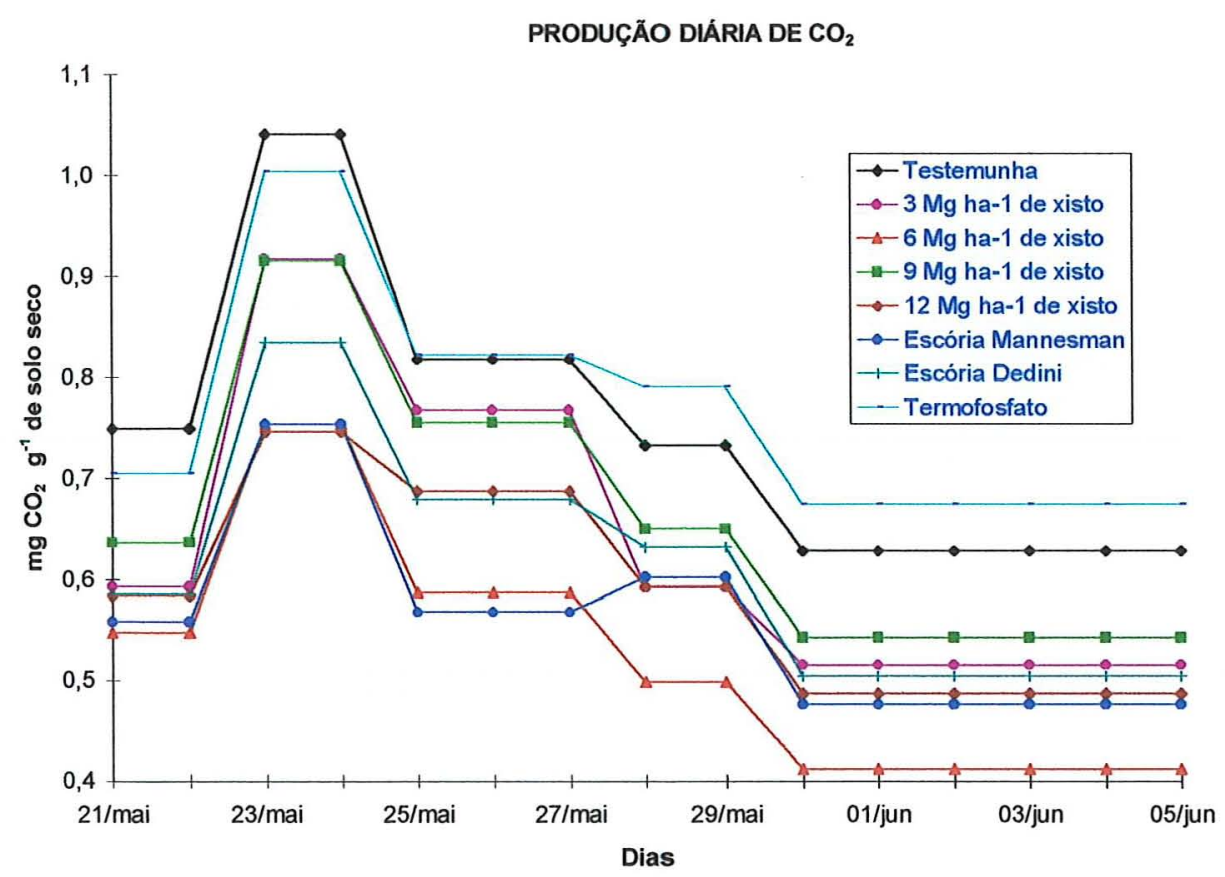

Figura 4. Produção diária de $\mathrm{CO}_{2}$ em amostras de solo não ativado do experimento 1.

No experimento 2, algumas alterações foram verificadas. O tratamento com escória da Mannesman, foi o que apresentou maior liberação de $\mathrm{CO}_{2}$ no solo não ativado, diferindo estatisticamente da testemunha, da menor dose de xisto e da escória da 
Dedini. O tratamento com a maior dose de xisto também diferiu da testemunha e da menor dose de xisto com aumento na liberação de $\mathrm{CO}_{2}$. No solo ativado com açúcar do experimento 2 , os tratamento se apresentam com resultados diferentes, onde a escória da Dedini apresentou a menor liberação de $\mathrm{CO}_{2}$, diferindo estatisticamente da testemunha.

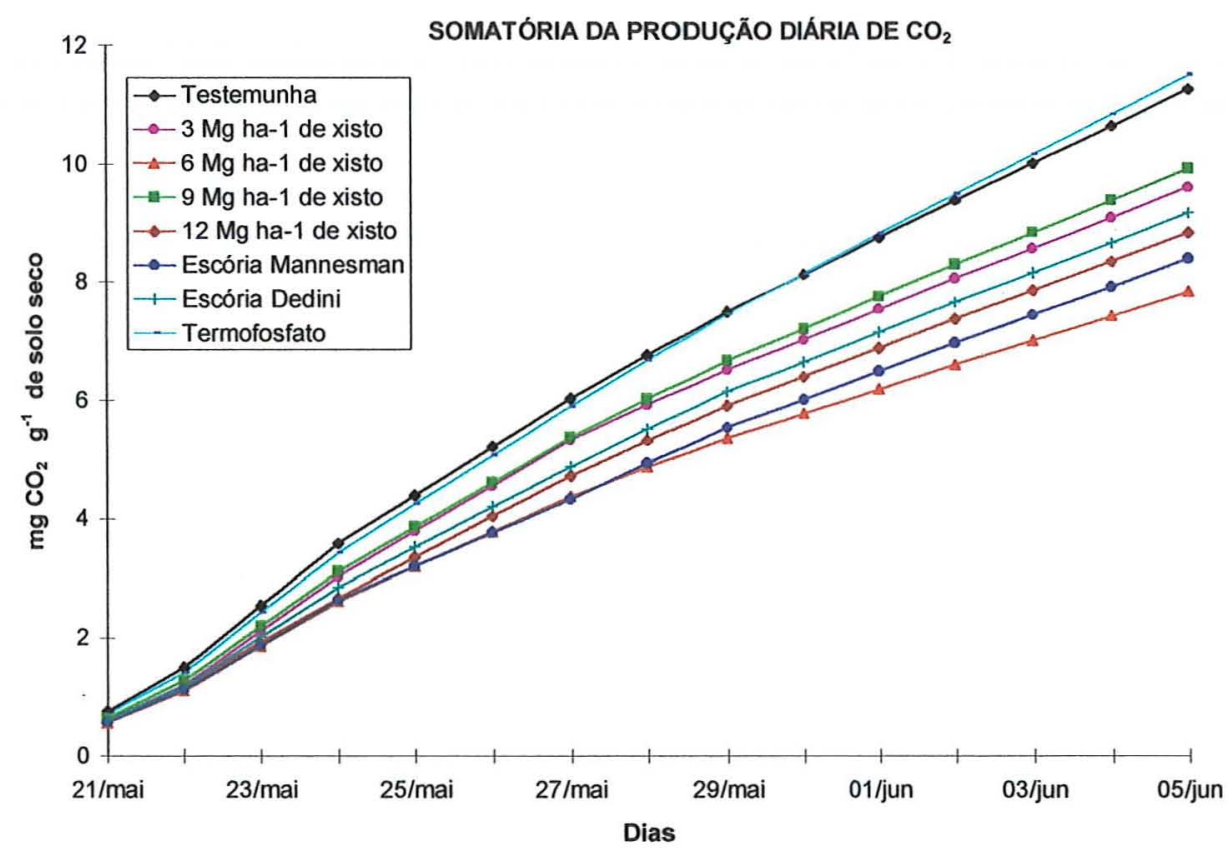

Figura 5. Produção diária acumulada de $\mathrm{CO}_{2}$ em amostras de solo não ativado do experimento 1 .

Através das figuras 4 e 5 verifica-se que os tratamentos se comportaram de maneira semelhantes, com elevação da respiração em todos os tratamentos até o terceiro dia e posterior redução, até estabilizar, a partir do décimo dia. O comportamento semelhante das curvas demonstra que não houve influência dos tratamentos na atividade microbiológica.

Nas figuras 6 e 7 são apresentados os resultados da liberação de $\mathrm{CO}_{2}$ do experimento 2, e nas figuras 8 e 9 são apresentados os resultados acumulados da liberação de $\mathrm{CO}_{2}$. 


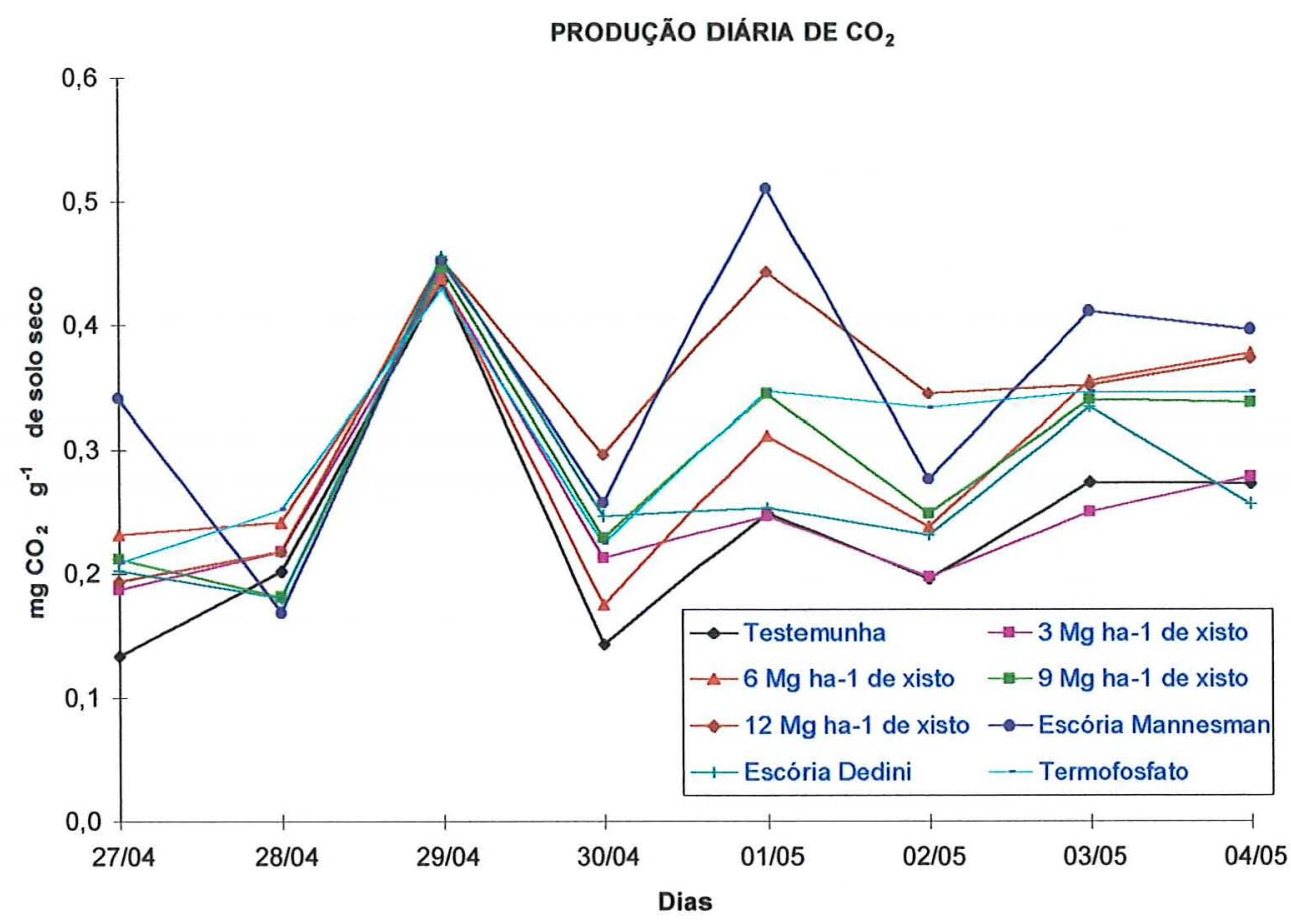

Figura 6. Produção diária de $\mathrm{CO}_{2}$ em amostras de solo não ativado do experimento 2 .

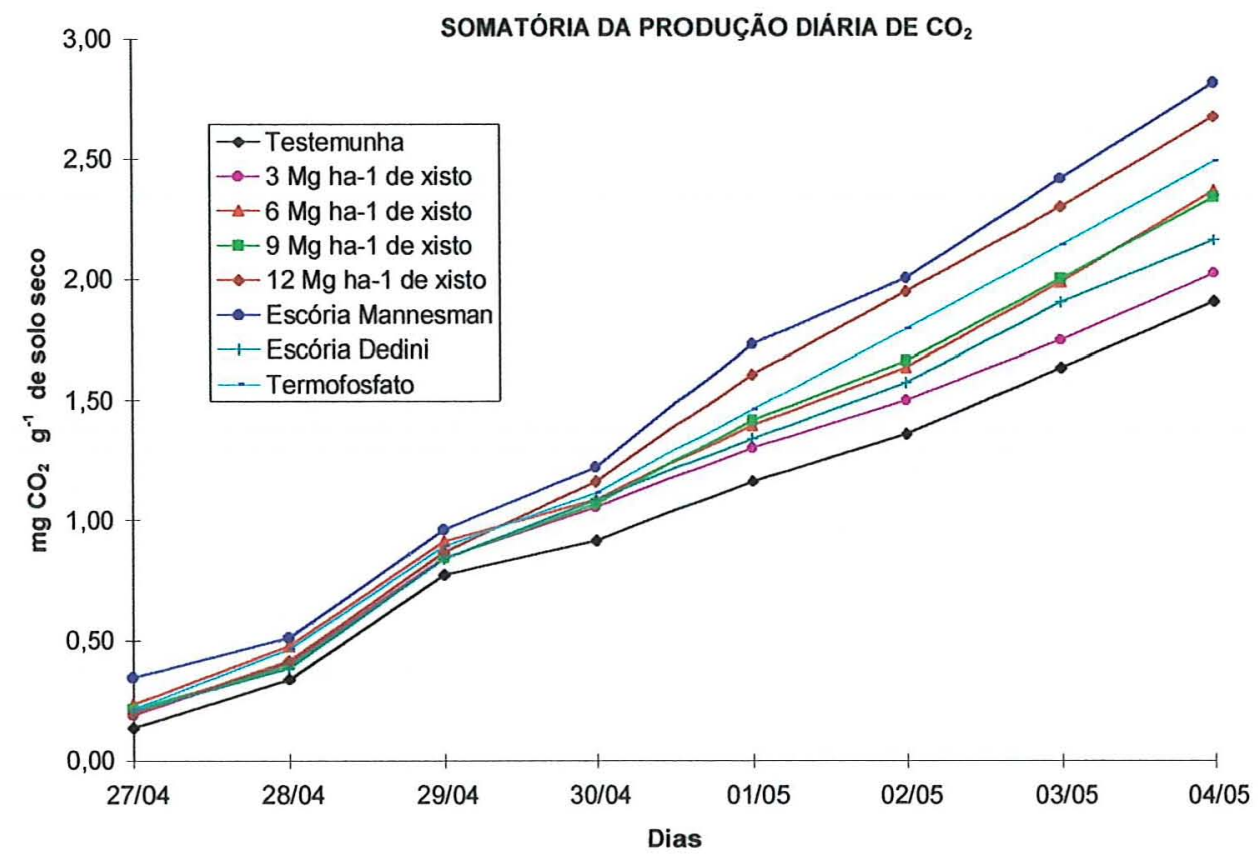

Figura 7. Produção diária acumulada de $\mathrm{CO}_{2}$ em amostras de solo não ativado do experimento 2 . 


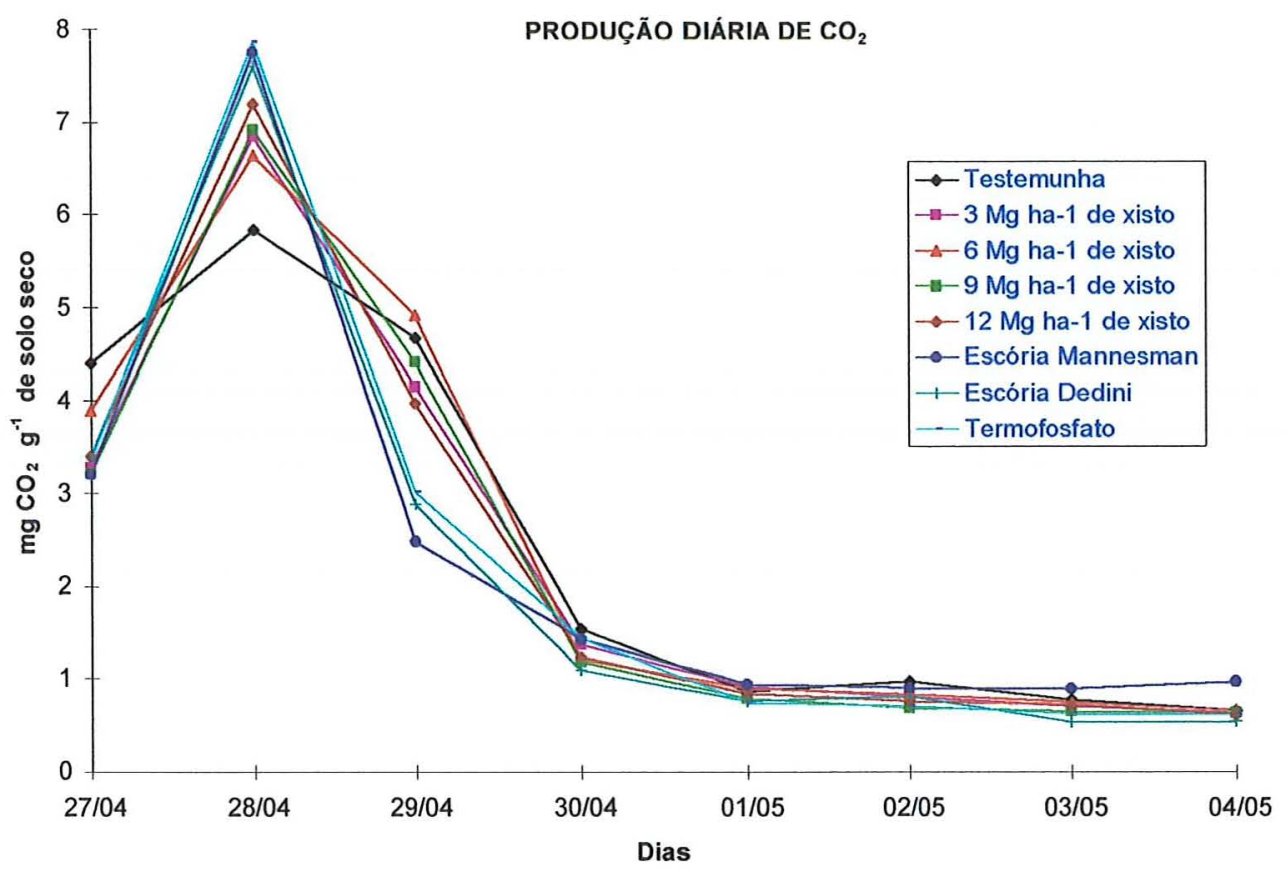

Figura 8. Produção diária de $\mathrm{CO}_{2}$ em amostras de solo ativado do experimento 2.

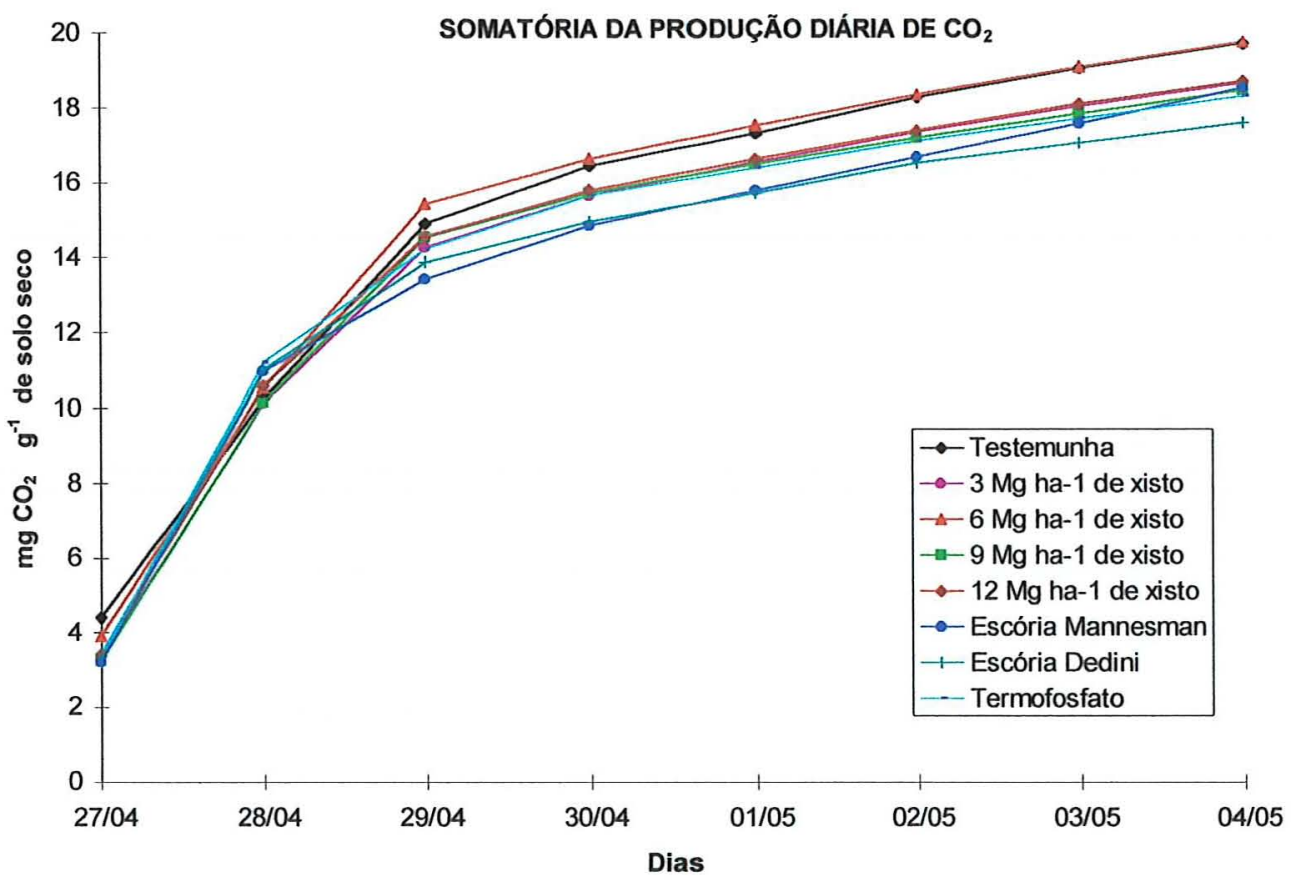

Figura 9. Produção diária acumulada de $\mathrm{CO}_{2}$ em amostras de solo ativado do experimento 2 . 
A evolução do $\mathrm{CO}_{2}$ no solo não ativado do experimento 2 (Figura 6) apresentou-se de forma oscilatória, entre dias com maior e dias com menor liberação de $\mathrm{CO}_{2}$. Não verificou-se tendência das curvas em aumentar ou diminuir a respiração dos microorganismos. Este tipo de curva, demonstra a presença de elementos de baixa decomposição ou matéria orgânica estável no solo. Embora as curvas apresentem comportamento semelhante fica evidente na Figura 6, que os tratamentos testemunha e 3 $\mathrm{Mg} \mathrm{ha}^{-1}$ de xisto, apresentaram as menores atividades a partir do quarto dia, sendo que os demais tratamentos apresentaram maior atividade. Observa-se também que os tratamentos com escória da Mannesman e xisto $12 \mathrm{Mg} \mathrm{ha}^{-1}$, apresentaram as maiores atividades. Estes resultados não se repetiram no experimento 1, onde estes tratamentos apresentaram as menores atividades.

Com a ativação do solo, verifica-se aumento na liberação de $\mathrm{CO}_{2}$ com relação ao solo normal (não ativado). No solo ativado, o açúcar promove um rápido aumento na atividade microbiana, mas como é um produto rapidamente consumido pelos microorganismos, na velocidade que aumenta, também diminui. Pode-se observar, pela figura 8, que a ativação provocou maior aumento inicial na respiração do solo em todos os tratamento, enquanto que a testemunha apresentou uma elevação menor, indicando um favorecimento dos produtos no desenvolvimento inicial dos microorganismos, mas o tratamento testemunha se recuperou em seguida. $O$ formato das curvas por apresentarem semelhanças demonstram que os tratamentos não influenciaram de forma expressiva a atividade microbiana.

Nas tabelas 29 e 30 estão apresentados os resultados de contagens de fungos e bactérias em amostras de solo coletado após a colheita do tomateiro dos experimentos 1 e 2 .

Através dos resultados da tabela 29 , verifica-se que os tratamentos com xisto e escória da Dedini apresentaram redução no número de bactérias, quando comparados à testemunha, no experimento 1, mas não foram estatisticamente diferentes. Devido a pequeno aumento no número de bactérias no tratamento com escória da 
Mannesman, este diferiu dos com xisto $\left(3,6\right.$ e $\left.12 \mathrm{Mg} \mathrm{ha}^{-1}\right)$ e da escória da Dedini, não diferindo da testemunha.

Tabela 29. Contagem de fungos e bactérias do solo à 0-20 $\mathrm{cm}$ (Experimento 1).

\begin{tabular}{ccc}
\hline Tratamentos & Bactérias & $\begin{array}{c}\text { Fungos } \\
\end{array}$ \\
& $\times 10^{5} \mathrm{~g}^{-1}$ de solo & $4,7 \mathrm{BC}$ \\
\hline Testemunha & $14,4 \mathrm{AB}$ & $6,3 \mathrm{ABC}$ \\
Xisto $\left(3 \mathrm{Mg} \mathrm{ha}^{-1}\right)$ & $7,8 \mathrm{~B}$ & $6,6 \mathrm{ABC}$ \\
Xisto $\left(6 \mathrm{Mg} \mathrm{ha}^{-1}\right)$ & $8,5 \mathrm{~B}$ & $9,3 \mathrm{AB}$ \\
Xisto $\left(9 \mathrm{Mg} \mathrm{ha}^{-1}\right)$ & $9,7 \mathrm{AB}$ & $10,3 \mathrm{~A}$ \\
Xisto $\left(12 \mathrm{Mg} \mathrm{ha}^{-1}\right)$ & $7,6 \mathrm{~B}$ & $8,8 \mathrm{ABC}$ \\
Escória (M) & $16,4 \mathrm{~A}$ & $4,2 \mathrm{C}$ \\
Escória (D) & $7,6 \mathrm{~B}$ & $7,8 \mathrm{ABC}$ \\
Termofosfato & $13,1 \mathrm{AB}$ & 27,2 \\
C. V. $(\%)$ & 28,1 & $4,9 * *$ \\
Valor de F & $5,4 * *$ & 4,7 \\
DMS (5\%) & 7,1 &
\end{tabular}

Obs.: Médias seguidas pela mesma letra, não diferem entre si, pelo teste Tukey ao nível de $5 \%$.

* Teste F significativo a $5 \% ; * *$ Teste F significativo a $1 \%$

Tabela 30. Contagem de fungos e bactérias do solo (Experimento 2).

\begin{tabular}{clrccccc}
\hline & \multicolumn{3}{c}{ Bactérias $\times 10^{5} \mathrm{~g}^{-1}$ de solo } & \multicolumn{3}{c}{ Fungos $\times 10^{2} \mathrm{~g}^{-1}$ de solo } \\
Tratamentos & $0-10 \mathrm{~cm}$ & \multicolumn{2}{c}{$10-20 \mathrm{~cm}$} & $0-10 \mathrm{~cm}$ & \multicolumn{2}{c}{$10-20 \mathrm{~cm}$} \\
\hline Testemunha & 12,0 & 12,3 & $\mathrm{BC}$ & 33,0 & 19,8 & $\mathrm{D}$ \\
Xisto $\left(3 \mathrm{Mg} \mathrm{ha} \mathrm{h}^{-1}\right)$ & 12,0 & 13,2 & $\mathrm{BC}$ & 27,9 & 58,5 & $\mathrm{ABC}$ \\
Xisto $\left(6 \mathrm{Mg} \mathrm{ha}^{-1}\right)$ & 12,4 & 17,1 & $\mathrm{AB}$ & 28,9 & 52,3 & $\mathrm{ABCD}$ \\
Xisto $\left(9 \mathrm{Mg} \mathrm{ha}^{-1}\right)$ & 14,2 & 9,3 & $\mathrm{C}$ & 47,3 & 64,6 & $\mathrm{AB}$ \\
Xisto $\left(12 \mathrm{Mg} \mathrm{ha}^{-1}\right)$ & 11,0 & 8,7 & $\mathrm{C}$ & 40,9 & 76,3 & $\mathrm{~A}$ \\
Escória (M) & 11,2 & 22,9 & $\mathrm{~A}$ & 29,0 & 33,6 & $\mathrm{BCD}$ \\
Escória (D) & 11,6 & 10,6 & $\mathrm{BC}$ & 31,9 & 30,6 & $\mathrm{CD}$ \\
Termofosfato & 11,1 & 15,1 & $\mathrm{BC}$ & 32,0 & 63,6 & $\mathrm{AB}$ \\
\hline C. V. (\%) & 19,0 & 21,4 & & 27,3 & 27,4 & \\
Valor de F & 0,82 & 10,3 & $* *$ & 2,16 & 8,3 & $*$ \\
DMS (5\%) & 5,4 & 6,9 & & 21,9 & 32,4 & \\
\hline
\end{tabular}

Obs.: Médias seguidas pela mesma letra, não diferem entre si, pelo teste Tukey ao nível de $5 \%$.

* Teste F significativo a $5 \% ; * *$ Teste $\mathrm{F}$ significativo a $1 \%$

Quanto à contagem de fungos, ao contrário do que ocorreu com as bactérias, os tratamentos de maneira geral aumentaram a quantidade de fungos em relação à testemunha (com exceção da escória da Dedini) sendo que a dose de $12 \mathrm{Mg}$ ha ${ }^{-1}$ 
de xisto foi significativamente diferente quando comparada à testemunha e a escória da Dedini.

No experimento 2 não foram verificados variações significativas tanto de fungos, quanto de bactérias na camada superficial do solo $(0-10 \mathrm{~cm})$. Na camada $10-$ $20 \mathrm{~cm}$, observa-se aumento dos fungos em função do aumento nas doses de xisto, sendo que as doses 3,9 e $12 \mathrm{Mg}^{-1}$ foram significativamente diferentes à testemunha. Observa-se também que as escórias (Dedini e Mannesman) também aumentaram a quantidade de fungos, mas não significativos em relação à testemunha, enquanto, que o termofosfato também apresentou aumento significativo, quando comparado à testemunha.

Nas amostras $10-20 \mathrm{~cm}$ do experimento 2 , verificou-se variação na contagem de bactérias. O tratamento com escória da Mannesman apresentou aumento significativo no número de bactérias, diferindo da testemunha, esta escória também diferiu significativamente das doses de xisto; com exceção do tratamento com $6 \mathrm{Mg}^{\mathrm{h}}{ }^{-1}$ de xisto. A diferença mais significativa ocorreu com os tratamentos com xisto, nas doses 9 e $12 \mathrm{Mg} \mathrm{ha}^{-1}$, que apresentaram redução no número de bactérias, mas não diferindo da testemunha.

$\mathrm{Na}$ análise de contagem de bactérias, o xisto apresentou sempre aumento com a elevação das doses, ocorrendo queda nas maiores doses, isto é detectado nos resultados analíticos a $10-20 \mathrm{~cm}$ no experimento 2 , onde a dose $6 \mathrm{Mg}^{-1}$ diferiu estatisticamente das de 9 e $12 \mathrm{Mg} \mathrm{ha}^{-1}$.

Não se verificou relação clara entre o número de fungos e bactérias e a liberação de $\mathrm{CO}_{2}$ no solo. Pode-se, observar que os produtos podem modificar o número de determinadas populações de indivíduos devido as alterações que estes causam ao solo, como valor $\mathrm{pH}$, disponibilidade de nutrientes e compostos orgânicos. No experimento 2 , os tratamentos que apresentaram as maiores atividades microbianas no solo não ativado foram os tratamentos com escória da Mannesman e o xisto na dose de $12 \mathrm{Mg} \mathrm{ha}^{-1}$, os quais apresentaram maior número de bactérias e de fungos na camada $10-20 \mathrm{~cm}$ de solo. Enquanto que no experimento 1, estes mesmos tratamentos, também apresentaram maior 
número de bactérias e de fungos, mas as menores liberações de $\mathrm{CO}_{2}$. A testemunha no experimento 2, apresentou o menor número de fungos a $10-20 \mathrm{~cm}$ de solo, e neste experimento também apresentou a menor liberação de $\mathrm{CO}_{2}$ no solo não ativado, enquanto que, no experimento 1, este mesmo tratamento apresentou o menor número de fungos e não apresentou a menor liberação de $\mathrm{CO}_{2}$. Mas, um fato, deve ser verificado, o solo do experimento 1 apresentou população bem menor de microorganismos que o solo do experimento 2 , isto pode ter influenciado a falta de significância no experimento 1 .

\subsection{Avaliação da produção de tomate}

No experimento 1 a colheita do tomate foi iniciada no dia 21 de agosto de 1997, e se estendeu até o dia 17 de outubro de 1997, ocorrendo em média uma colheita a cada 5 dias, totalizando 11 colheitas, conforme Figuras 10 e 11. Na Tabela 31 são apresentados os resultados médios da produção final $\left(\mathrm{kg} \mathrm{parcela}^{-1}\right)$, número e peso médio de frutos.

Tabela 31. Produção final média de tomate, número e peso médio de frutos (Experimento 1).

\begin{tabular}{|c|c|c|c|}
\hline Tratamentos & $\begin{array}{c}\text { Produção } \\
\left(\text { kg parcela }^{-1}\right)\end{array}$ & $\begin{array}{l}\text { Número de frutos } \\
\text { (frutos parcela }{ }^{-1} \text { ) }\end{array}$ & $\begin{array}{l}\text { peso médio de } \\
\text { frutos parcela }\end{array}$ \\
\hline Testemunha & 72,25 & 782,53 & 88,83 \\
\hline Xisto $3 \mathrm{Mg} \mathrm{ha}{ }^{-1}$ & 96,46 & 981,95 & 102,23 \\
\hline Xisto $6 \mathrm{Mg} \mathrm{ha}^{-1}$ & 92,79 & 1034,99 & 91,92 \\
\hline Xisto $9 \mathrm{Mg} \mathrm{ha}{ }^{-1}$ & 78,59 & 843,01 & 92,88 \\
\hline Xisto $12 \mathrm{Mg} \mathrm{ha}^{-1}$ & 86,80 & 894,92 & 98,60 \\
\hline Escória (M) & 76,63 & 778,75 & 101,45 \\
\hline Escória (D) & 83,23 & 906,09 & 92,80 \\
\hline Termofosfato & 84,12 & 877,89 & 96,72 \\
\hline C.V. $(\%)$ & 12,20 & 15,12 & 7,83 \\
\hline Valor F (trat.) & 2,47 & 1,77 & 1,66 \\
\hline DMS (5\%) & 24,26 & 318,26 & 17,77 \\
\hline
\end{tabular}

Obs.: parcela $=10,5 \mathrm{~m}^{2}$

Médias seguidas pela mesma letra, não diferem entre si, pelo teste Tukey ao nivel de $5 \%$.

* Teste F significativo a 5\%; ** Teste F significativo a 1\% 


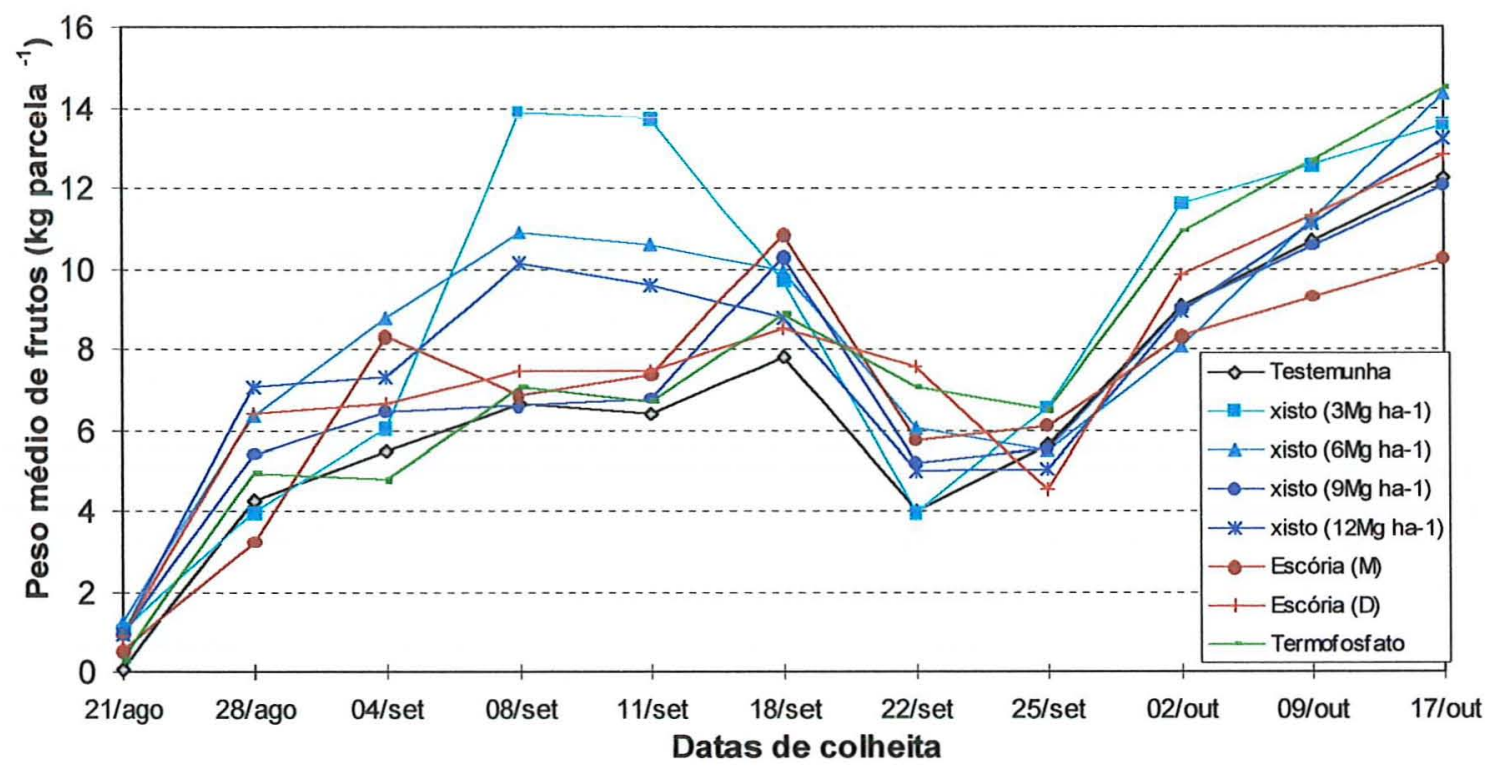

Figura 10. Peso médio das colheitas em $\mathrm{kg}$ por parcela $\left(\right.$ parcela $=10,5 \mathrm{~m}^{2}$ ) do experimento 1, em funçãos das datas de colheita.

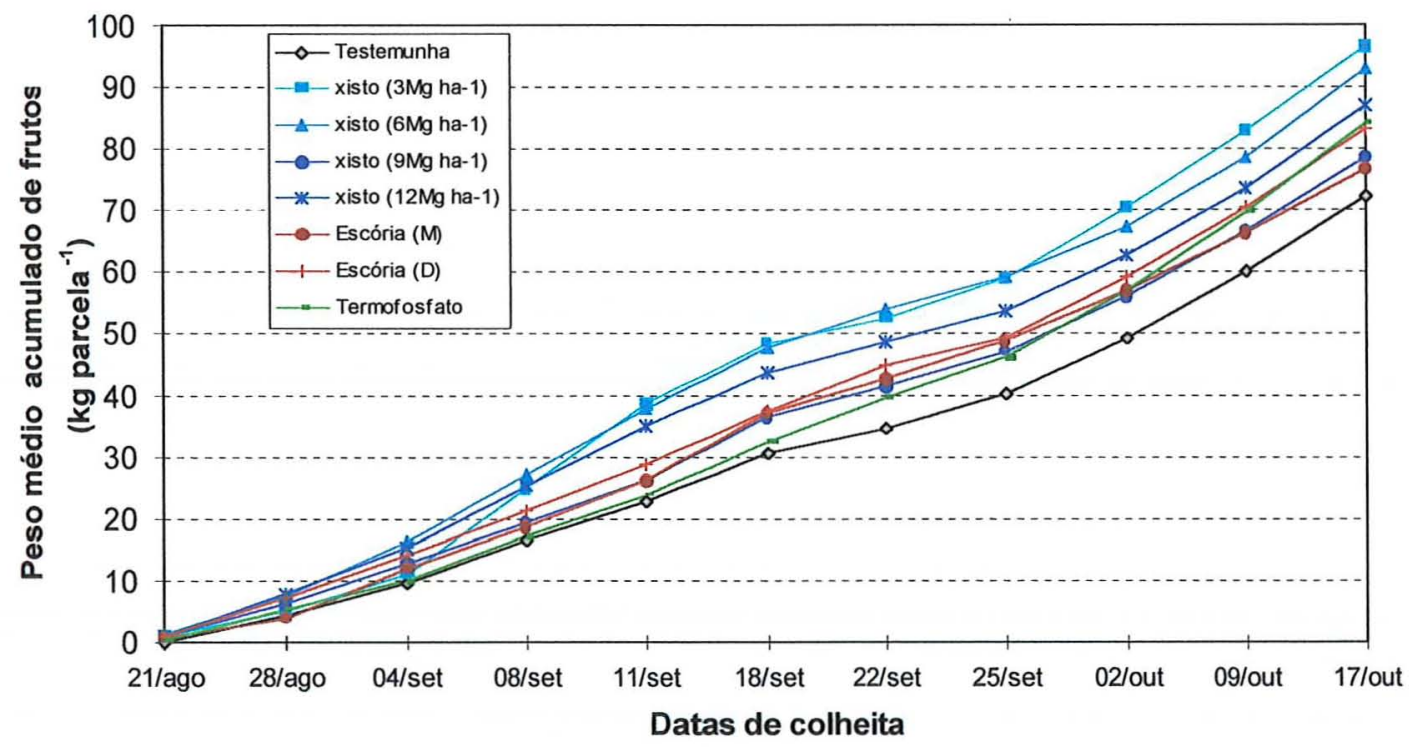

Figura 11. Peso médio acumulado das colheitas em $\mathrm{kg}$ por parcela $\left(\right.$ parcela $\left.=10,5 \mathrm{~m}^{2}\right)$ do experimento 1 em funçãos das datas de colheita..

No experimento 2, a colheita do tomate foi iniciada no dia 03 de agosto de 1998, e se estendeu até o dia 01 de outubro de 1997, ocorrendo em média uma colheita a cada 3,5 dias, totalizando 19 colheitas, conforme Figuras 12 e 13. Na Tabela 32 são 
apresentados os resultados médios da produção final $\left(\mathrm{kg}_{\text {parcela }}{ }^{-1}\right)$, número e peso médio de frutos.

Tabela 32. Produção final média de tomate, número peso médio de frutos (Experimento 2).

\begin{tabular}{|c|c|c|c|}
\hline Tratamentos & $\begin{array}{c}\text { Produção } \\
\left(\text { kg parcela }^{-1}\right)\end{array}$ & $\begin{array}{l}\text { Número de frutos } \\
\text { (frutos parcela }^{-1} \text { ) }\end{array}$ & $\begin{array}{l}\text { peso médio de } \\
\text { frutos parcela }\end{array}$ \\
\hline Testemunha & 107,33 & 982,68 & 109,32 \\
\hline Xisto $3 \mathrm{Mg} \mathrm{ha}^{-1}$ & 108,14 & 1009,35 & 107,27 \\
\hline Xisto $6 \mathrm{Mg} \mathrm{ha}^{-1}$ & 106,30 & 969,38 & 109,79 \\
\hline Xisto $9 \mathrm{Mg} \mathrm{ha}^{-1}$ & 114,42 & 1046,38 & 109,29 \\
\hline Xisto $12 \mathrm{Mg} \mathrm{ha}^{-1}$ & 122,15 & 1117,88 & 109,02 \\
\hline Escória (M) & 116,05 & 1046,22 & 111,22 \\
\hline Escória (D) & 121,49 & 1102,36 & 110,15 \\
\hline Termofosfato & 121,78 & 1109,47 & 109,58 \\
\hline C.V. (\%) & 8,54 & 8,35 & 4,01 \\
\hline Valor F (trat.) & 1,91 & 1,76 & 0,26 \\
\hline DMS (5\%) & 23,24 & 207,59 & 10,41 \\
\hline
\end{tabular}

Obs.: parcela $=10,5 \mathrm{~m}^{2}$

Médias seguidas pela mesma letra, não diferem entre si, pelo teste Tukey ao nível de $5 \%$.

* Teste F significativo a $5 \% ; * *$ Teste $\mathrm{F}$ significativo a $1 \%$

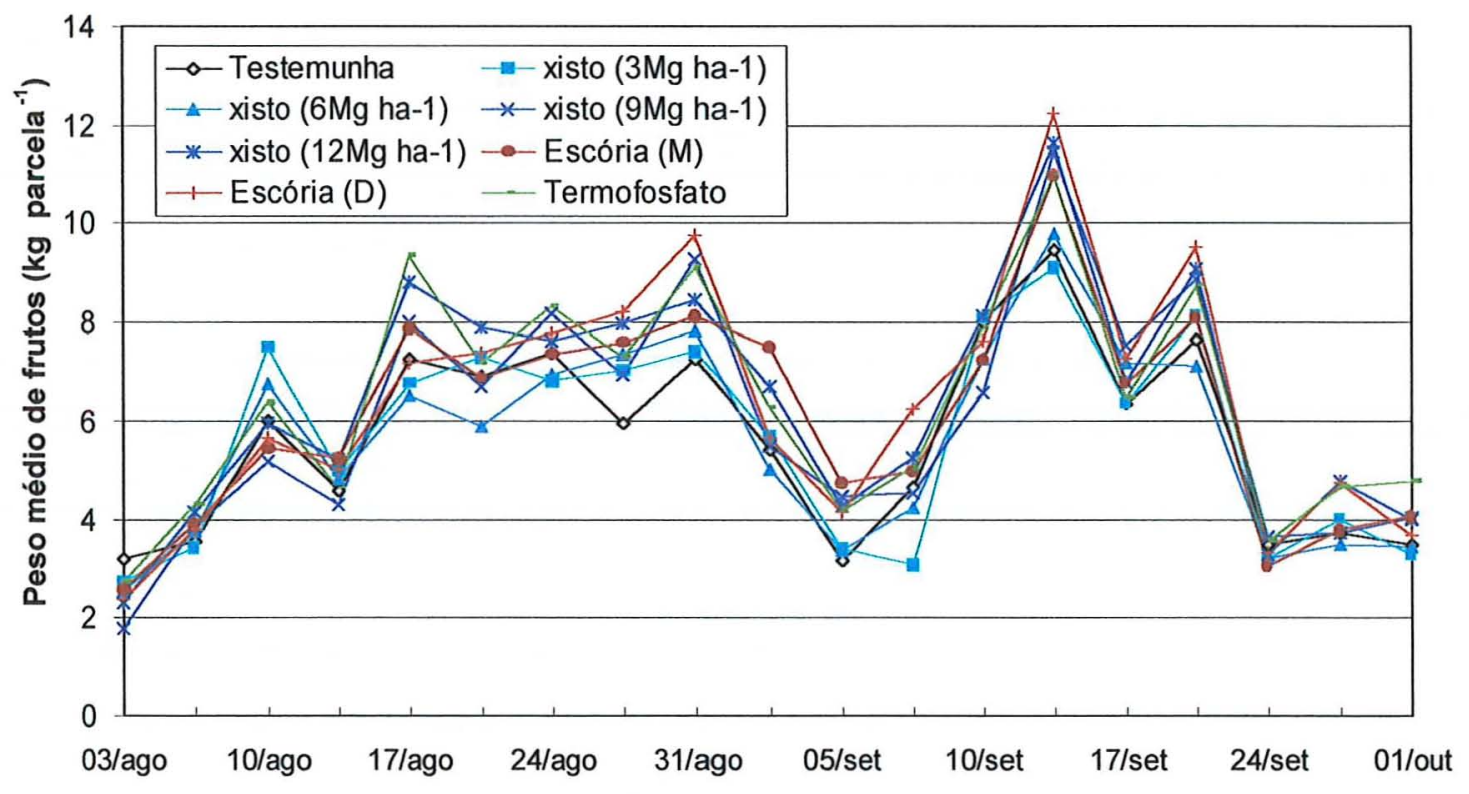

Datas de colheita

Figura 12. Peso médio das colheitas em $\mathrm{kg}$ por parcela $\left(\right.$ parcela $=10,5 \mathrm{~m}^{2}$ ) do experimento 2 em funçãos das datas de colheita. 


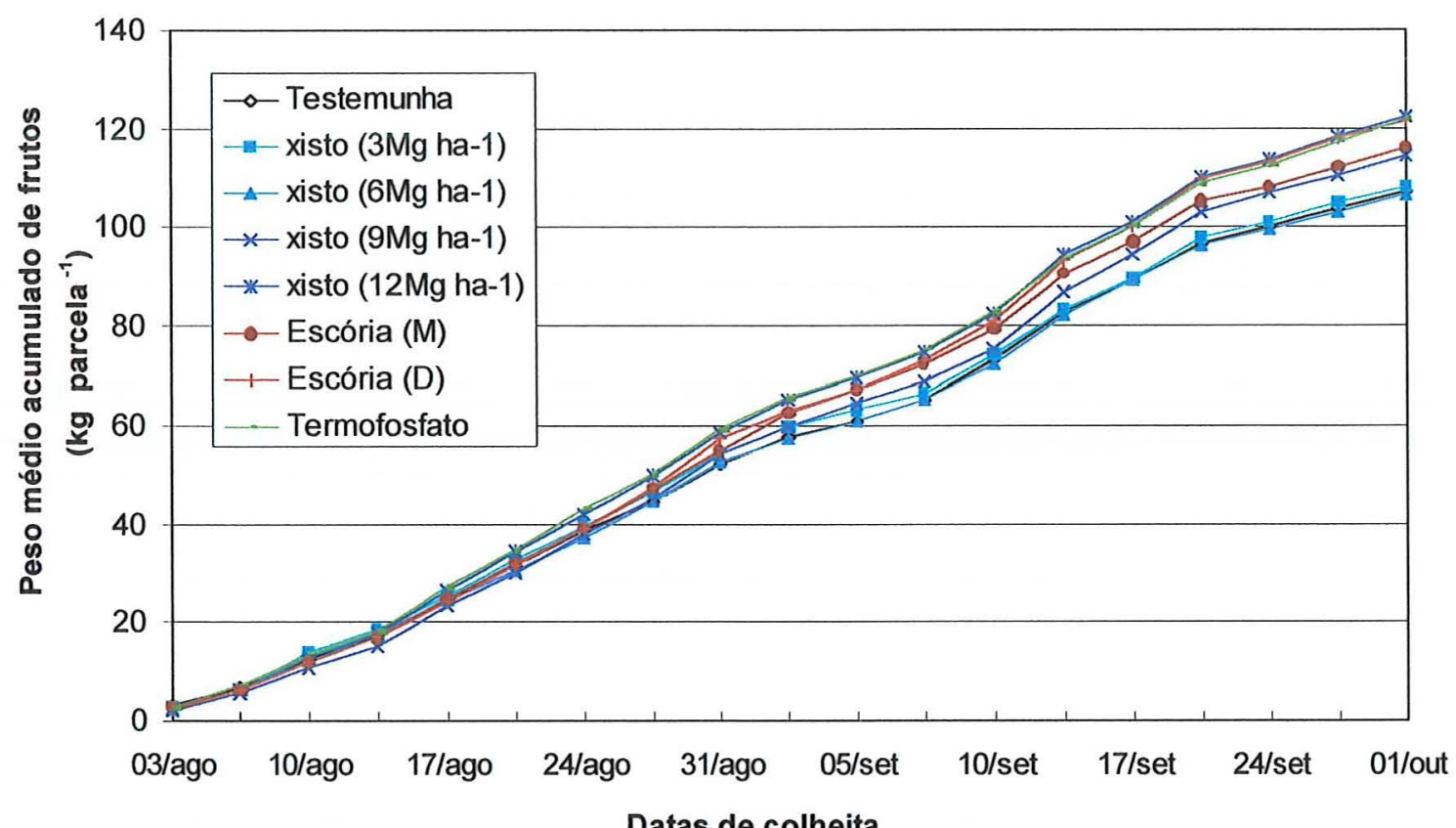

Figura 13. Peso médio acumulado das colheitas em $\mathrm{kg}$ por parcela $\left(\right.$ parcela $\left.=10,5 \mathrm{~m}^{2}\right)$ do experimento 2 em funçãos das datas de colheitas.

Analisando-se os resultados de produção, observa-se que não houve diferenças significativas entre os tratamentos, tanto no experimento 1 , como no experimento 2. Embora sem significância, quase todos os tratamentos apresentaram aumentos de produtividade quando comparados à testemunha. No experimento 1 as maiores produtividades foram verificadas nos tratamentos com as doses menores de xisto. No 2, foi a maior dose de xisto que apresentou maior resposta.

Quanto ao número e peso médio de frutos, observa-se que também não há diferenças significativas entre os tratamentos dos dois experimentos. 


\section{CONCLUSÕES}

As escórias atuaram com eficiência na correção da acidez do solo; os silicatos aumentaram a disponibilidade de fósforo;

O xisto e as escórias aumentaram o teor de silício no solo e na planta e o xisto se mostrou eficiente no fornecimento de enxofre para a cultura aumentando seu teor no solo e na planta;

A análise de silicio pelo método azul em material vegetal se mostrou apresentar resultados mais confiaveis, apresentando menos problemas analíticos e maior repetibilidade, em relação ao método amarelo;

A escória da Mannesman aumentou a população bacteriana do solo enquanto que o xisto aumentou a população fungica.

O termofosfato e a escória da Dedini foram os tratamentos que mais alteraram os teores de metais no solo e nas plantas, mas não verificou-se danos aos mesmos, tanto por parte de contaminações químicas por metais pesados, como diminuição da atividade biológica do solo, bem como diminuição na produtividade do tomate.

Os produtos aplicados e nas doses determinadas podem ser usados na agricultura, sejam como corretivos ou como condicionadores de solo, mas trabalhos utilizando-se de doses mais elevadas de xisto devem ser conduzidos para melhor avaliar seus efeitos no solo e nas culturas. 


\section{REFERÊNCIAS BIBLIOGRÁFICAS}

ALLAWAY, W. H. Agronomic controls over the environmental eyeing of trace elements. Advances in Agronomy. v.20, p.235-274, 1968.

ALLOWAY, B. J. Heavy metals in soils. New York: John Wiley, 1990. p.100-121: Cadmium.

ALOISI, R. R. Deposição de resíduos da industria citrica em solos de textura média. Piracicaba, 1995. 252 p. Tese (Livre Docência) Escola Superior de Agricultura "Luiz de Queiroz", Universidade de São Paulo.

ANDERSON, D. L.; JONES, D. B.; SNYDER, G. H. Response of a rice sugarcane rotation to calcium silicate slag on Everglades Histosols. Agronomy Journal, v.79, n.3, p.531-535, 1987.

ANTONOVICS, J.; BRADSHAW, A. D.; TURNER, R. G. Heavy metals tolerance in plants. Advances in Ecological Research, v.7, n.1, p.1-85, 1971.

ASHA, J.; DUTTA, S. A. Impact of distillery effluent application to land on soil microflora. Environmental Monitoring and Assessment. v.15, n.2, p.201-210, 1990. 
BAKER, J. C.; SCRIVNER, C. L. Simulated movement of silicon on Typic Hapludalf. Soil Science, v.139, n.3, p.265-61, 1985.

BAKER, J. C.; YOUNG, B. A. Vegetative filter treatment of dairy wastewater and lot runoff in Southern Appalachia. In: INTERNATIONAL SYMPOSIUM ON AGRICULTURAL WASTES, 5th. Chicago, 1985. Agricultural waste utilization and management. St. Joseph: ASAE, 1985. p.745-758.

BARTLET, R. J. ; KIMBLE, J. M. Behavior of chromium in soils. I. Trivalent forms. Journal of Environmental Quality, v.5, n.4, p.379-383, 1976.

BATAGliA, O. C.; FURLANI, A. M. C.; TEIXEIRA, J. P. F.; FURLANI, P. R.; GALLO, J. R. Métodos de análise química de plantas. Campinas: Instituto Agronômico, 1983. 48p. (IAC. Boletim Técnico, 78)

BELANGER, R. R.; BOWEN, P. A.; EHRET, D. L.; MENZIES, J. G. Soluble silicon. Its role in crop and disease management old greenhouse crops. Plant Disease, v.79, n.4, p.329-336, 1995.

BERGER, K. C.; TRUOG, E. Boron determination in soils and plants using the quinazizarin reaction. Industrial and Engineering Chemistry, v.11, n.3, p.540$545,1939$.

BEYER, L. ; BLUME, H. P. ; MUELLER, K. ; SCHLEICH-SAIDFAR, C. The application of secondary paper mill sludge's on arable soils to improve soil fertility. Journal of Agronomy and Crop Science, v.169, n.5, p.336-346, 1992. 
BIGARELLA, J. J. Geologia da Formação Irati. In: SIMPÓSIO SOBRE CIÊNCIA E TECNOLOGIA DO XISTO. Rio de Janeiro, 1975. Rio de Janeiro :Academia Brasileira de Ciência, 1975. p. 1-79.

BINGHAM, F. T.; PAGE, A. L.; MAHLER, R. L.; GANJE. T. J. Growth and cadmium accumulation of plants grown on a soil treated with cadmium enriched sewage sludge. Journal of Environmental Quality, v.4, n.2, p.207-211, 1975.

BRADY, N. C. The nature and properties of soil. New York: Macmillan Publishing Company, Ed. 10, 1990.621p.

BROWN, K.C.; DONNELLY, K.C.; DEUEL, L.E. Effects of mineral nutrients, sludge application rate, and application frequency on biodegradation of two oil sludges. Microbial Ecology, v. 9, n. 2, p.363-373, 1983.

CAÑADAS, R. C.; SANCCHIDRIAN, J. R.; RIVERO, V. C. Distribuicion de Pb, Cd, $\mathrm{Cu}$ y $\mathrm{Cr}$ entre distintas fases sólidas en algunos tipo de suelos. Anales Edafologia y Agrobiologia, v.45, n.5/6, p. 613-630, 1986.

CARR, L. E.; MOORE, R. C.; MERKA, W. C.; SCHALLES, F. D. Land disposal of dissolved air flotation slugde from poultry processing. Transactions of the ASAE, v.31, n.2, p.462-465, 1988.

CHAUDRY, F. M.; WALLACE, A.; MUELLER, R. T. Barium toxicity in plants. Communications in Soil Science and Plant Analysis, v.8, n.8, p.795-800, 1977.

COREY, J.C. Management of soil systems for industrial wastes. In: NELSON, D. W.; ELRICK, D. E.; TANGI, K. K. (Ed.). Chemical mobility and reactivity in soil 
systems. Madison: Soil Science Society of America, 1984. p. 257-262. (Special Publication 11)

DAVIES, B. E.; ROBERTS, L. J. The distribuition of heavy metal contaminated soils in Northeast Clwyd, Wales. Water, Air and Soil Pollution. v.9, n.4, p.507-518, 1978.

DAVIS, G. Oil shale. In: AMERICA SOCIETY AGRICULTURAL. Reclamation of drastically disturbed lands. Madison, 1978. p. 609-618.

DOWDY, R. H.; VOLK, V. V. Movement of heavy metals in soils. In: NELSON, D. W.; ELRICK, D. E.; TANGI, K. K. (Ed.). Chemical mobility and reactivity in soil systems. Madison: Soil Science Society of America, 1984. p. 229-240. (Special Publication 11)

DRYSDALE, A. B. Land disposal of beet-ethanol wastes. In: INTERNATIONAL SYMPOSIUM ON AGRICULTURAL WASTES, 5. Chicago, 1985. Agricultural waste utilization and management, St Joseph: ASAE, 1985. p.538-545.

ELAWAD, S. H.; GREEN Jr., V. E. Silicon and the rice plant environmental: a review of recent research. Revista IL RISO, v.28, n.2, p.235-253, 1979.

ELGAWHARY, S. M.; LINDSAY, W. L. Solubility of silica in soil. Soil Science Society of American Journal, v.36, n.3, p.430-433, 1972.

EPSTEIN, E. Nutrição mineral das plantas: princípios e perspectivas. São Paulo: EDUSP, 1975. 341p. (Livros Técnicos e Científicos).

FIRME, D. J. Enriquecimento e fusão de escória de siderurgia com fosfato natural. Viçosa, 1986. 54p. Dissertação (Mestrado) - Universidade Federal de Viçosa. 
FONSECA, M. C.; FONSECA, M. V. A.; CUNHA, T. P.; SANTOS, P. S. Estudos comparativos preliminares de caracterização química e mineralógica de amostras de xisto original e pirolisado do processo Petrosix. Cerâmica, v.30, n.174, p.145-160, 1984a.

FONSECA, M. C.; FONSECA, M. V. A.; CUNHA, T. P.; SANTOS, P. S. Estudo das propriedades após a queima em atmosfera oxidante, do xisto pirolisado do processo Petrosix. Cerâmica, v.30, n.175, p.183-198, 1984b.

FONSECA, M. V. A. Estudo da lixiviação ácida do resíduo de retortagem do xisto. Rio de Janeiro, 1983. 180 p. Dissertação (Mestrado) - Universidade Federal do Rio-de Janeiro.

FOX, R. L.; SILVA, J. A.; YOUNGUE, O. R.; PLUCNETT, D. L.; SHERMAN, G. D. Soil and plant silicon and silicate response by sugarcane. Soil Science Society of America Proceedings, v.31, n.6, p.775-779, 1967.

FRANSWAY, D. F.; WAGENET, R. J. Salt release and movement in process oil shale. Journal of Environmental Quality, v.10, n.1, p.107-113, 1981.

FURLANI, P. R.; GALLO, J. R. Determinação de silício em material vegetal pelo método colorimétrico do "azul-de-molibdênio". Bragantia, v.37, n.1, p.5-11, 1978.

GERRITSE, R. G.; DRIEL, W. van The relationship between adsorption of trace metals, organic matter, and $\mathrm{pH}$ in temperate soils. Journal of Environmental Quality, v.13, n.2, p.197-204, 1984. 
GRATT, L. B. Risk analysis of hazardous materials in oil shale. Journal Hazardous Materials, v.10, n.2/3, p.317-334, 1985.

GROSSI SAD, J. H.; SARAIVA, N. T. A.; PINTO, C. P. Rochas oleigenas da formação Irati, área da usina industrial Paraná. Belo Horizonte: GEOSOL, v.1, 1984. 95p. (Relatório final)

GUICHET, J.; JAMBU, P.; DINEL, H.; Changes in the organic matter of a rendzina soil caused by wastewater sludge disposals from dairy processing plants. Pédologie, v.41, n.2, p.149-162, 1991.

HANDLEY, L. L.; EKERN, P. C. Effluent irrigation of para grass: water, nitrogen, and biomass budgets. Water Resources Bulletin, v.20, n.5, p.669-677, 1984.

HARTZ, K. E.; BHAGAT, S. K.; STARLIN, L. A.; MOTT, H. V.; KRIVANEK, K. R. Attenuation of leachate generated from co-disposal of volcanic ash and solid waste. Pullman:Report-Washington State University, Water Research Center, v. 60, 1984. p. 230.

HINGSTON, F. J.; POSNER, A. M.; QUIRK, J. P. Anion adsorption by goethite and gibbsite. I. The role of the proton in determining adsorption envelopes. The Journal of Soil Science, v.23, n.2, p.177-192, 1972.

HOPPS, H. C.; CARLISLE, E. M.; McKEAGUE, J. A.; SIEVER, R. Van SOEST, P. J. Silicon. In: MERTZ, W. (Ed.) Geochemistry and the environment. Washington: National Academic Society, 1977. v.2, p. 54-72. 
HORNICK, S. B.; FISHER, R. H.; PAOLINI, P. A. Petroleum wastes. In: PARR, J. F.; MARSH, P. B.; KLA, J. M. (Ed.) Land treatment of hazardous wastes. New Jersey: Noyes Data Corporation, p.321-337. 1983.

HORNICK, S. B.; KAUFMAN, D. D. Textile wastes. In: PARR, J. F.; MARSH, P. B.; KLA, J. M. (Ed.) Land treatment of hazardous wastes. New Jersey: Noyes Data Corporation, p.388-396. 1983.

HUTTON, J. T. Titanium and zirconium minerals. In: DIXON, J. B.; WEED, S. B.; KITTRICK, J. A.; MILFORD, M. H.; WHITE, J. L. Mineral in soil environmental. Madison: Soil Science Society of America, 1977. p.673-688.

ILER, R. K. The chemistry of silica; solubility, polymerization, colloid and surface properties, and biochemistry. New York: John Wiley and Sons, 1979. 787p.

INTERNATIONAL RICE RESEARCH INSTITUTE. Soils and rice. Los Banos, 1978. $825 p$.

JAHNEL, M. C. Método de plaqueamento por gotas e outros parâmetros microbiológicos na avaliação da degradação de lodo ativado de curtume em solos. Piracicaba, 1997, p. 79. Tese (Doutorado) - Escola Superior de Agricultura "Luiz de queiroz" da Universidade de São Paulo.

JARDIM, W. F. Metais pesados, um dano irreparável. Revista Brasileira de Tecnologia, v.14, n.2, p.41-45, 1983.

JONES, L. H. P.; HANDRECK, K. A. Silica in soils, plants and animals. Advances in Agronomy, v.19, p.107-149, 1967. 
KABATA, A. J.; PENDIAS, H Trace elements in soils and plants. Boca Raton: CRC Press, 1984. 315p.

KAUFMAN, D. D. Pesticide and organic chemical manufacturing wastes. In: PARR, J. F.; MARSH, P. B.; KLA, J. M. (Ed.) Land treatment of hazardous wastes. New Jersey: Noyes Data Corporation, 1983. p.310-320.

KILKELLY, M. L.; LINDSAY, W. L. Selected trace elements in plants grown on retorted oil shale. Journal of Environmental Quality, v.11, n.3, p.422-427, 1982.

KILMER, V. J. Silicon. In: BLACK, C. A. (Ed.) Methods of soil analysis. Madison: American Society of Agronomy, 1965. pt 1, p.959-962. (Agronomy, 9)

KING, L. D. Land application of untreated industrial waste water. Journal of Environmetal Quality, v.11, p.638-644, 1982.

KITASHI, K.; YAMANE, I. Heavy metal polluition in soil of Japan. Tokyo: Japan Science Society Press, 1981. 328p.

KLIPPEL, R. W.; HAGARMAN, J. A.; WILLS, R. H. Landfilling air pollution dusts from specialty steel production on a solvay process wastebed. In: LaGREGA, M. D.; HENDRIAN, L. K. Toxid and hazardous waste, Maryland: Butterworth Publishers, 1983. p.472-476.

LINDSAY, W. L. Chemical equilibrium in soils. New York: John Wiley, 1979. 449 p.

LINDSAY, W. L.; MORVELL, W. A. Development of a DTPA soil test for zinc, iron, manganese and copper. Soil Science Society of America Journal, v.42, n.3, p.421$428,1978$. 
LINDSAY, W. L. M.; PEECH, H.; CLARK, J. S. Solubility criteria for the existence de variscite in soils. Soil Science Society of America Proceedings, v.10, n.1, p.71-80, 1945.

MALAVOLTA, E. Manual de química agrícola. Piracicaba:Agronômica Ceres, 1976. $527 \mathrm{p}$.

MALAVOLTA, E. Elementos de nutrição mineral de plantas. São Paulo: Agronômica Ceres, 1980. $251 \mathrm{p}$.

MALAVOLTA, E; VITTI, G. C.; OLIVEIRA, S. A. Avaliação do estado nutricional das plantas: principios e aplicações. Piracicaba: POTAFOS, 1997. $201 \mathrm{p}$.

MARSCHNER, H. Mineral nutrition of higher plants. San Diego: Academic Press, 1986. 674p.

MCKEAGUE, J. A.; CLINE, M. G. Silica in soils. Advances in Agronomy v.15, p.339-397, 1963.

MEHLICH, A. Mehlich 3 soil test extractant: A modification of Mehlich 2 extractant. Communications in Soil Science and Plant Analysis, v.15, n.12, p.1409-1416, 1984.

MITSUI, S.; TAKATOH, H. Nutritional study of silicon in graminaceous crops. Part I. Soil Science and Plant Nutrition, v. 9, n.1, p.49-53, 1963.

MIYAKE, Y.; TAKAHASHI, E. Silicon deficiency of tomato plant. Soil Science and Plant Nutrition, v.24, n.1, p.175-189, 1978. 
NAFTEL, J. A. Soil liming investigation: IV. Response of crimson clover to boron with and without lime on coastal plain soils. Journal of the American Society of Agronomy , v.34, n.2, p.975-985, 1942.

NEIVA, J. Fontes alternativas de energia: conservação de energia, carvão vegetal, álcool etílica e xisto. 2.ed. Rio de Janeiro: Maity Comunicação, 1987. 200p.

NEMETH, J. C. Concept and design-parameter considerations in land treatment of industrial wastes. In: ALLEMAN, J. E.; KAVANAGH, J. T. Industrial wastes. Ann Arbor: Science Publ., 1982. p.45-52.

NOGUCHI, H.; ITO, H. Long-term experiment of applying slugde fertilizer to agricultural land. Journal of the Institution of Water and Environmental Management, v.6, n.5, p.576-582, 1992.

OBIHARA, C. H.; RUSSEL, E. W. Specific adsorption of silicate and phosphate by soils. The Journal of Soil Science, v.23, n.1, p.105-117, 1972.

OVERCASH, M. R.; HUMENIK, F. J.; MINER, J. R. Livestock waste management. Boca Raton: CRC Press, 1983. v.2, 244p.

PASSOW, H.; ROTHSTEIN, A.; CLARKSON, T. W. The general pharmacology of the heavy metals. Pharmacological Reviews, v.13, n.1, p.185-244, 1961.

PATTERSON, J. H.; DALE, L. S.; CHAPMAM, J. F. Trace element partitioning during the retorting of Condor and Rundle oil shales. Environmental Science \& Technology, v.22, n.5, p.532-537, 1988. 
PIAU, W. C. Viabilidade do uso das escórias como corretivos e fertilizantes. Piracicaba, 1991. 99p. Dissertação (Mestrado) - Centro de Energia Nuclear na Agricultura, Universidade de São Paulo.

PIAU, W. C. Efeito de escória de siderurgia em atributos químicos de solos e na cultura do milho (Zea mays L.). Piracicaba, 1995. 124p. Tese (Doutorado) - Centro de Energia Nuclear na Agricultura, Universidade de São Paulo.

PLUCKNETT, D. L. The use soluble silicate in Hawaiian agriculture. University of Qeensland Papers, v.1, n.6, p.203-223, 1972.

PONNAMPERUMA, D. L. The chemistry of submerged soils. Advances in Agronomy, v.24, p.29-96, 1972.

PRIEN, C. Current developments in world oil shale technology. In: SINPÓSIO SOBRE CIÊNCIA E TECNOLOGIA DO XISTO. Rio de Janeiro, 1975. Rio de Janeiro:Academia Brasileira de Ciência, 1975. p.1-41

PROCHNOW, L. I. Disponibilidade de fósforo da fração solúvel em citrato neutro de amônio e insolúvel em água de fosfatos acidulados. Piracicaba, 1996. 157p. Tese (Doutorado). Escola Superior de Agricultura "Luiz de Queiroz" - Universidade de São Paulo.

PORTO, M. L. Vegetação metalófita e o desenvolvimento do setor mineral. In: SIMPÓSIO DO TRÓPICO ÚMIDO, 2. Belém, 1986. Anais. Belém: EMBRAPA, CPATU, 1986. p. 171-183.

RAIJ, B. van Avaliação da fertilidade do solo. Piracicaba: POTAFOS, 1983. 142p. 
RAIJ, B. van; QUAGGIO, J. A. Métodos de análise de solo para fins de fertilidade. Campinas: Instituto Agronômico, 1983. 31p. (IAC. Boletim Técnico 81).

REDDY, K. J.; LINDSAY, W. L. The solubility relationships of calcium and magnesium minerals in processed oil shells. Journal of Environmental Quality, v. 15, n.1, p.1-4, 1986.

REIFENBERG, A.; BUCKWOLD, S. J. The release of silica from soil by the orthophosphate anion. The Journal of Soil Science, v.5, n.1, p. 105-117, 1954

REYNOLDS, J. H. Land application of wastewater. Journal Water Pollution Control Federation, v.51, n.6, p.1276-1281, 1979.

RITTER, W. F. Land disposal of high grease content poultry processing slugde. In: INTERNATIONAL SYMPOSIUM ON AGRICULTURAL WASTES, 5. Chicago, 1985. Agricultural waste utilization and management. St. Joseph: ASAE, 1985. p.560-568.

RITTER, W. F.; EASTBURN, R. P. Effect of poultry processing sludge on groundwater quality and soil properties. In: SPECIALTY CONFERENCE ON ENVIRONMENTALLY SOUND WATER AND SOIL MANAGEMENT, New York, 1982. Proceedings, New York: American Society of Civil Engineers, 1982. p.159-166.

RODRIGUES, M.; LOPEZ, F. A.; PINTO, M.; BALCÁZAR, N.; BESGA, G. Basic Linz-Donawtz slag as liming agent for pastureland. Agronomy Journal, v.86, n.5, p. 904-909, 1994. 
ROGALA, F. Produção, caracterização e processamento de biossólidos. In: SEMINÁRIO SOBRE GERENCIAMENTO DE BIOSÓLIDOS DO MERCOSUL, 1. Curitiba, 1998. Anais, Curitiba:SANEPAR/ABES, 1998. p.35-40.

ROSS, L.; NABABSING, P.; CHEONG, Y. W. Y. Residual effect of calcium silicate applied to sugarcane soils. In: INTERNATIONAL CONGRESS OF THE SOCIETY OF SUGAR CANE TECHNOLOGY, 15. Durban, 1974. Proceedings, Durban:ISSCT, 1974. v.2, p.539-542.

RUSSELL, J. M.; COOPER, R. N.; LINDSAY, S. B. Reuse of wastewater from meat processing plants for agricultural and forestry irrigation. Water Science and Technology, v.24, n.9, p.277-286, 1991.

SCHWAB, A. P.; LINDSAY, W. L.; SMITH, P. J. Elemental contents of plants growing on soil-covered retorted shale. Journal of Environmental Quality, v.12, n.3, p.301-304, 1983.

SEAKER, E. M. Zinc, copper, cadmium and lead in minespoil, water, and plants from reclaimed mine land amended with sewage sludge. Water, Air, Soil Pollution, v.57, n.1, p.849-859, 1991

SIMON, Z.; TEDESCO, M. J.; GIANELLO, C. Long-term land application of activated sludge from petrochemical wastewater treatment plant: I. Leachate Quality. Water Science and Technology, v.24, n.11, p.19-31, 1991.

SIVARAJASINGHAM, S.; ALEXANDER, L. T.; CADY, J. C. ; ClinE, M. G. Laterite. Advances in Agronomy, v.14, p.1-60, 1962. 
SMITH, B. F. L. The determination of silicon in ammonium oxalate extracts of soils. Communications in Soil Science and Plant Analysis, v.15, n.3, p.199-204, 1984.

SMYTH, J. J.; SANCHEZ, P. A. Effects of lime, silicate and phosphorus applications to an oxissol on phosphorus sorption and ion retention. Soil Science Society of America Journal, v.44, n.3, p.500-505, 1980.

SNYDER, G. H.; JONES, D. B.; GASCHO, G. J. Silicon fertilization of rice on Everglades Histosols. Soil Science Society of America Journal, v.50, n.5, p.1259$1263,1986$.

SOUZA, E. C. A.; YASUDA, M. Uso agronômico de termofosfato no Brasil. São Paulo: Fertilizantes Mitsui, 1995. 59p.

STARK, J. M.; REDENTE, E. F. Trace element and salt movement in retorted oil shale disposal sites. Journal of Environmental Quality, v.15, n.13, p.282-288, 1986.

STARK, J. M.; REDENTE, E. F. Plant uptake and cycling of trace elements on retorted oil shale disposal piles. Journal of Environmental Quality, v.19, n.3, p.495-501, 1990.

STEVENSON, F. J. Organic matter reactions involving metal ions in soil. In:WILLEY, J. Humus chemistry: genesis, composition, reactions. New York: Macmillan , 1982. p. 337-354.

STOZKY, G. Microbial respiration. In: BLACK, C. A. (Ed.) Methods of soil analysis. Madison: American Society of Agronomy, 1965. pt 2, p.1550-1572. (Agronomy 9). 
TAKAHASHI, E. Uptake mode and physiological functions of silica. In: FOOD AND AGRICULTURE POLICY RESEARCH CENTER. Science of the rice plant: Physiology. Tokyo, 1996. v.2, p. 420-433.

TAUCHNITZ, J.; SCHNABEL, R.; KIESEL, G; OTTO,M.; HANRIEDER,H. Land disposal of industrial wastes products 28 . Effects of plants on the solubility of heavy metals compounds. Hercynia, v.2, n. 2, p.332-335, 1983.

TAYLOR, A. W. Review of the effects of siliceous dressing on the nutrient status of soils. Journal of Agricultural and Food Chemistry, v.9, n.1, p.163-165, 1961.

TEDESCO, M.; LIGO, M.; GIANELLO, C.; SIMON, Z. Effect of petrochemical activated sludge on soil properties. Water Science and Technology, v.20, n.10, p.63-74, 1988

TISDALE, S. L.; NELSON, W. L.; BEATON, J. D. Soil fertility and fertilizers. New York: Macmillan, $1985.754 \mathrm{p}$.

TRANI, P. E.; RAIJ, B. van Hortaliças. In: RAIJ, B. van; R.; CANTARELLA; QUAGGIO, J. A.; FURLANI, A. M. C. Recomendação de adubação e calagem para o Estado de São Paulo. Campinas: Instituto Agronômico, p.155-186, 1996. (IAC. Boletim Técnico 100)

TURTURA, G. C.; MORSELli, M. Agricultural uses of waste-treatment sludge. Rivista di Agronomia, v.25, n.3, p.391-399, 1991.

UHLEN, G. The effect of calcium silicate in barley pot experiments. Journal of the Scientific Agricultural Society of Finland, v.46, n.3, p.296-306, 1974. 
VORM, P. D. J. van der. Uptake of Si by five plant species, as influenced by variation in Si supply. Plant and Soil, v.56, n. 1, p.152-156, 1980.

VITTI, G. C. Avaliação e interpretação do enxofre no solo e na planta. Jaboticabal: FUNEP, 1989. 37p.

WALLACE, A; WALLACE, G. A. A possible flaw in EPA's 1993 new sludge rule due to heavy metal interactions. Communications in Soil Science and Plant Analysis, v. 25, n. $1 / 2$, p. $129-135,1994$.

WEISS, A.; HERZOG, A. Isolation characterization of a silicon-organic complex from plants. In: BENDZ, G.; LINDVIST, I. Biochemistry of silicon and related problems. New York: Plenum, 1978. p. 109-127.

WERNER, D; ROTH, R. R. Silica metabolism. In: LAUCHLI, A; BIELESKI, R. L. Inorganic plant nutrition. New York: Spring Verlag. 1983. p. 682-694. (Encyclopedia Plant Physiol, 15B).

WHITE, R. P. Effects of lime upon soil as plant manganese levels in acid soils. Soil Science Society of America Proceedings, v.34, n.1, p.62-69, 1937.

WYNN PARRY, D.; SMITHSON, F. Type of opaline silica deposition in the leaves of Bright grasses. Annals of Botany, v.28, p.169-185, 1964. 